UNIVERSIDADE DE BRASÍLIA

FACULDADE DE CIÊNCIAS DA SAÚDE

PROGRAMA DE PÓS-GRADUAÇÃO EM CIÊNCIAS DA SAÚDE

SIMONE BATISTA PIRES SINOTI

EFEITO DO CLORETO DE TRIBUTILESTANHO SOBRE O PERFIL GLICOLIPÍDICO EM CAMUNDONGOS C57BL/6

BRASÍLIA 


\section{EFEITO DO CLORETO DE TRIBUTILESTANHO SOBRE O PERFIL GLICOLIPÍDICO EM CAMUNDONGOS C57BL/6}

Dissertação apresentada como requisito parcial à obtenção do Título de Mestre em Ciências da Saúde pelo Programa de Pós-Graduação em Ciências da Saúde da Universidade de Brasília.

Orientador: Prof. Dr. Luiz Alberto Simeoni Co-orientadora: Prof ${ }^{a}$ Dra. Flora Aparecida Milton

BRASÍLIA 


\title{
EFEITO DO CLORETO DE TRIBUTILESTANHO SOBRE O PERFIL GLICOLIPÍDICO EM CAMUNDONGOS C57BL/6
}

\begin{abstract}
Dissertação apresentada como requisito parcial à obtenção do Título de Mestre em Ciências da Saúde pelo Programa de Pós-Graduação em Ciências da Saúde da Universidade de Brasília.
\end{abstract}

BANCA EXAMINADORA

Prof. Dr. Luiz Alberto Simeoni (Presidente) Universidade de Brasília

Profa. Dra. Maria de Fátima Borin Universidade de Brasília

Dr. Pedro Góes Mesquita

Laboratório Sabin de Análises Clínicas

Profa. Dra. Doralina do Amaral Rabello Ramos Universidade de Brasilia

BRASÍLIA 
Ficha catalográfica elaborada automaticamente, com os dados fornecidos pelo(a) autor(a)

BATISTA PIRES SINOTI, SIMONE

EFEITO DO CLORETO DE TRIBUTILESTANHO SOBRE O

Be PEREIL GLICOLIPIDICO EM CAMUNDONGOS C57BL/6 / SIMONE BATISTA PIRES SINOTI; orientador LUIZ ALBERTO SIMEONI; co-orientador FLORA APARECIDA MILTON. -Brasilia, 2017.

$97 \mathrm{p}$.

Dissertação (Mestrado - Mestrado em Ciências da Saúde) -- Universidade de Brasilia, 2017.

1. OBESIDADE. 2. DESREGULADORES ENDÓCRINOS. 3. CLORETO DE TRIBUTILESTANHO. 4. PPAR. 5. TECIDO ADIPOSO. I. ALBERTO SIMEONI, LUIZ, orient. II. APARECIDA MILTON, FLORA, co-orient. III. Titulo. 
Dedico este trabalho a minha base mais sólida de amor infinito e incondicional, meus filhos Luiz Gabriel e Carlos Eduardo.

Ao meu companheiro de jornada, André Luiz, quem escolhi para dividir a vida e me mostrou com seu apoio, cumplicidade e incentivo que a vida pode ser mais leve quando se anda de braços dados. 


\section{AGRADECIMENTOS}

Primeiramente a Deus, a quem busquei força e coragem nas horas difíceis e confiei o sucesso em suas mãos.

À minha família, meus filhos e esposo, por entender os momentos de ausência e incentivar o meu crescimento acadêmico.

Ao meu orientador Professor Luiz Simeoni, que me mostrou com carinho e firmeza que posso alcançar meus objetivos. Seus ensinamentos, apoio, carinho e respeito serão guardados sempre em meu coração.

Ao Professor Francisco, agradeço a oportunidade de voltar ao meio acadêmico, e por acreditar no meu potencial me incentivando a galgar degraus cada vez mais altos. Obrigada por todos os ensinamentos e por me mostrar que questionar e acima de tudo persistir nos faz mais sábios e ativos na busca do conhecimento.

À minha co-orientadora Flora, que me guiou e mostrou que somos capazes de realizar nossos sonhos. A palavra obrigada é pouco para expressar o meu sentimento de gratidão. Mais que uma amiga, você se tornou para mim, um exemplo de determinação, competência e profissionalismo. Sua paciência e o seu incentivo jamais serão esquecidos. Agradeço por tudo, desde a minha chegada ao laboratório até a conclusão desse trabalho.

Às profas. Angélica e Michella pelas discussões e valiosas contribuições durante toda execução desse trabalho. Aos demais professores do Farmol, Adriana, Djane, Fátima, Guilherme, Carine e Marie pelos ensinamentos e colaboração.

Aos estagiários Gabriela, Pedro, Matheus e a PIBIC Luisa Doca, o meu muito obrigada. A dedicação e comprometimento de vocês tornaram os momentos de trabalho mais leves e prazerosos.

Aos colegas de laboratório, que se tornaram grandes amigos, que mesmo longe geograficamente, como a Camila, ou mais próximo como a Anna, Ana, Anyk, Adria, Alexandre, Bel, Bruna, Carolina, Caroline, Cibele, Cinthia, Daniela, Erica, Fernanda, Gleice, Hanna, Isadora, Janice, Kim, Laísa, Mariana, Michelly, Natália, Paloma, Pedro, Ráiza, Sarah, Sidney, Wanessa e Yuri, tornaram meus dias melhores, sejam com uma 
conversa ou tomando juntos um café na copa, todos vocês me fizeram sentir bem em estar todos os dias no laboratório, levarei todos para sempre no meu coração.

Ao Henrique por dividir experiências de bancada e pelas longas conversas cheias de incentivo e animação.

À Mariella pelo apoio, ensinamentos e carinho conferidos a mim durante todo o mestrado.

Ao Kaian, que me ajudou nas horas em que o meu computador conspirava contra $\operatorname{mim}$.

À Rilva, pelos ensinamentos e as conversas que tornaram meus dias mais fáceis.

Aos técnicos de laboratório Luciano e Glorinha por sua contribuição e auxílio.

Aos técnicos do biotério, na pessoa do Emiraldo, obrigada pela ajuda e cuidados com os animais.

A minha mãe, Irene (in memoriam), que além de ter sido uma mãe excepcional, sempre me incentivou em todas as minhas escolhas e seu legado de perseverança e força me tornou a pessoa que sou. Ao meu pai, meu irmão pelo carinho e incentivo.

Aos membros da banca examinadora, por disponibilizarem seu tempo e terem aceitado o convite, contribuindo para a melhoria desse trabalho.

Aos porteiros, auxiliares de limpeza e demais servidores da universidade, que com um sorriso e um bom dia me fez senti acolhida todos os dias.

A todos aqueles que, de alguma forma, estiveram próximos a mim, fazendo esta vida valer cada vez mais a pena.

Ao Conselho Nacional de Desenvolvimento Científico e Tecnológico (CNPq) por financiar e apoiar esse trabalho. 
"A alegria não chega apenas no encontro do achado, mas faz parte da busca".

(Paulo Freire) 


\section{RESUMO}

A obesidade afeta grande parte da população mundial, tornando-se um fator de risco para doenças como hipertensão, doenças cardiovasculares e diabetes tipo 2. Além da alimentação, fatores genéticos e estilo de vida, a obesidade pode estar associada à exposição de poluentes químicos capazes de funcionar como desreguladores endócrinos (DE). O cloreto de tributilestanho (TBTC) caracterizado como DE é capaz de ativar os receptores nucleares PPARy e RXR, promovendo a adipogênese. Neste contexto, este estudo investigou os efeitos diretos do TBTC no metabolismo de camundongos $\mathrm{C} 57 \mathrm{~B} \mathrm{I} / 6$ submetidos à dieta normolipídica ou dieta hiperlipídica. Os camundongos alimentados com dieta normolipídica foram tratados com TBTC diluído na água de beber, nas concentrações de 1,5 , ou $25 \mu \mathrm{g} / \mathrm{Kg}$, e apresentaram tendência de maior ganho de massa corporal com o tratamento de TBTC na concentração de $5 \mu \mathrm{g} / \mathrm{kg}$. Os animais alimentados com a dieta hiperlipídica e induzidos à hiperglicemia foram tratados com rosiglitazona $10 \mathrm{mg} / \mathrm{Kg}$ ou GQ-16 $40 \mathrm{mg} / \mathrm{Kg}$ (ambos compostos sensibilizantes de insulina), ou TBTC nas concentrações de 1 ou $5 \mu \mathrm{g} / \mathrm{kg}$. Os animais tratados com rosiglitazona e GQ-16 apresentaram os níveis glicêmicos reduzidos, porém o mesmo não foi observado para os animais tratados com TBTC. Não houve diferença estatística significante entre os grupos no que se refere às massas do tecido adiposo branco e ao consumo de água e dieta, tanto nos animais alimentados com a dieta normolipídica quanto hiperlipídica. No tecido adiposo marrom dos animais alimentados com a dieta hiperlipídica, o grupo tratado com rosiglitazona apresentou um aumento na massa enquanto o grupo tratado com GQ16 apresentou uma redução na massa quando comparados ao controle. Neste mesmo tecido, rosiglitazona e TBTC $5 \mu \mathrm{g} / \mathrm{kg}$, na análise morfológica, mostraram um maior acúmulo de lipídios. Também foi observado no tecido hepático dos animais alimentados com dieta hiperlipídica, uma maior quantidade de gotas lipídicas nos hepatócitos dos grupos tratados com rosiglitazona e TBTC $5 \mu \mathrm{g} / \mathrm{Kg}$. Estes resultados sugerem que o TBTC na concentração de $5 \mu \mathrm{g} / \mathrm{kg}$ pode induzir esteatose hepática em camundongos $\mathrm{C} 57 \mathrm{BI} / 6$.

Palavras-chave: obesidade, desreguladores endócrinos, cloreto de tributilestanho, PPAR, tecido adiposo. 


\begin{abstract}
Obesity affects large part of the world's population, becoming a risk factor for diseases such as hypertension, cardiovascular disease and type 2 diabetes. In addition to diet, genetic factors and lifestyle, obesity may be associated with exposure of chemical pollutants, capable of functioning as endocrine disrupters (ED). Tributyltin chloride (TBTC) characterized as ED can activate nuclear receptors PPARy and RXR, promoting adipogenesis. In this context, this study investigated the direct effects of TBTC on the metabolism of $\mathrm{C} 57 \mathrm{BI} / 6$ mice submitted to the normolipid diet or hyperlipidic diet. The mice fed a normolipid diet were treated with TBTC - diluted in the drinking water - at concentrations 1,5 , or $25 \mu \mathrm{g} / \mathrm{Kg}$, showing a trend of greater body mass gain with TBTC treatment at $5 \mu \mathrm{g} / \mathrm{Kg}$. Animals fed with hyperlipidemic diet and hyperglycemia-induced were treated with rosiglitazone $10 \mathrm{mg} / \mathrm{kg}$ or GQ-16 $40 \mathrm{mg} / \mathrm{Kg}$ (both insulin sensitizing compounds), or TBTC at concentrations of 1 or $5 \mu \mathrm{g} / \mathrm{kg}$. Animals treated with rosiglitazone and GQ-16 had reduced glycemic levels, but this was not observed for the animals treated with TBTC. There was no statistically significant difference between the groups related with the masses of white adipose tissue and the consumption of water and diet, both in animals fed with normolipid diet and hyperlipid. In brown adipose tissue of the animals fed with hyperlipid diet, the rosiglitazone group showed a mass increase while the group treated with GQ-16 presented a mass reduction when compared to the control. In this same tissue, rosiglitazone and TBTC $5 \mu \mathrm{g} / \mathrm{kg}$ in the morphological analysis, showed a greater lipid accumulation. A higher amount of lipid droplets in the hepatocytes of the rosiglitazone and TBTC $5 \mu \mathrm{g} / \mathrm{kg}$ treated groups, was also observed in the hepatic tissue of the animals fed with hyperlipid diet. These results suggest that TBTC at $5 \mu \mathrm{g} / \mathrm{kg}$ concentration may induce hepatic steatosis in C57BI / 6 mice.
\end{abstract}

Keywords: obesity, endocrine disrupters, tributyltin chloride, PPAR, adipose tissue. 


\section{LISTA DE FIGURAS}

Figura 1 Fontes, vias de exposição, alvos metabólicos e efeitos fisiopatológicos de desreguladores endócrinos

Figura 2 Tributilestanho e trifenilestanho e seus respectivos produtos de desbutilação e desfenilação

Figura 3 Possíveis meios de entrada de compostos organoestânicos no ambiente

Figura 4 Organização estrutural e funcional dos receptores nucleares

Figura 5 Mecanismos de transcrição genética de PPAR

Figura 6 Massa corporal dos camundongos alimentados com dieta normolipídica

Figura 7 Consumo de dieta e água de camundongos alimentados com dieta normolipídica

Figura 8 Glicemia dos camundongos alimentados com dieta normolipídica

Figura 9 Massa dos tecidos e órgãos dos camundongos alimentados com dieta normolipídica

Figura 10 Massa corporal dos camundongos alimentados com dieta hiperlipídica

Figura 11 Consumo de dieta e água de camundongos alimentados com dieta hiperlipídica

Figura 12 Glicemia dos camundongos alimentados com dieta hiperlipídica

Figura 13 Massa dos tecidos e órgãos dos camundongos alimentados com dieta hiperlipídica

Figura 14 Imagem das lâminas histológicas de tecido adiposo marrom interescapular

Figura 15 Imagem das lâminas histológicas de tecido adiposo branco inguinal

Figura 16 Imagem das lâminas histológicas de tecido adiposo branco epididimal

Figura 17 Imagem das lâminas histológicas de tecido hepático 


\section{LISTA DE TABELAS}

Tabela 1 Dados da ingestão hídrica individual diária de cada concentração de TBTC

Tabela 2 Valor de $p$ e massa dos tecidos e órgãos dos camundongos alimentados com dieta normolipídica

Tabela 3 Dados da ingestão individual diária de TBTC, GQ-16 e rosiglitazona

Tabela $4 \quad$ Valor de $p$ e massa dos tecidos dos camundongos alimentados com dieta hiperlipídica

Tabela 5 Valor de $p$ e massa dos órgãos dos camundongos alimentados com dieta hiperlipídica. 


\section{LISTA DE ABREVIATURAS E SIGLAS}

3T3-L1 Pré-adipócitos murinos

A - BPA Bisfenol A

AMPK Proteína quinase

AVMA Associação americana de medicina veterinária

$\mathrm{BHCH} \quad$ Betaexaclorocicloexano

BVT.13 Hidrato de ácido benzoico 13

CCAAT Citosina/citosina/adenina/adenina/timina

C / EBPa Proteínas de ligação ao amplificador - alfa

C3H10T1/2 Células mesenquimais

CAS Chemical Abstract Service

CEUA Comissão de ética no uso animal

CONAMA Conselho nacional do meio ambiente

Cos $7 \quad$ Fibroblasto do rim de primata

Cys Cisteína

DBCA Diretriz brasileira para o cuidado e a utilização de animais para fins científicos

DBD - DNA DNA-binding domain

DBT Dibutilestanho

DDE Diclorodifenildicloroetileno

DE Desreguladores endócrinos

DNA Ácido desoxirribonucleico

DPT Difenilestanho

EPM Erro padrão da média

EUA Estados unidos da américa

GQ-16 5-(5-bromo-2-metóxi-benzilideno)-3-(4-metil-benzil) tiazolidina-2,4diona)

HCB Hexaclorobenzeno

IBMX Isobutilmetilxantina

IL-6 Interleucina-6

IMC Índice de massa corporal

IMO Organização marítima internacional 


$\begin{array}{ll}\text { JEG-3 } & \text { Células de coriocarcinoma } \\ \text { LBD } & \text { Ligand binding domain } \\ \text { MBT } & \text { Monobutilestanho } \\ \text { MPT } & \text { Monofenilestanho } \\ \text { OC } & \text { Oxiclordano } \\ \text { PBS } & \text { Tampão fosfato salino } \\ \text { PCB } & \text { Bifenil policlorado } \\ \text { PCDD } & \text { Dibenzodioxinas policloradas } \\ \text { PCDF } & \text { Dibenzofuranos policlorados } \\ \text { POPs } & \text { Poluentes orgânicos persistentes } \\ \text { PPAR } & \text { Receptores ativados por proliferador de peroxissoma } \\ \text { PPRE } & \text { Elemento responsivo aos proliferadores peroxissomais } \\ \text { PVC } & \text { Cloreto de polivinil } \\ \text { RN } & \text { Receptores nucleares } \\ \text { RNA } & \text { Ácido ribonucleico } \\ \text { RXR } & \text { Receptor retinóide } X \\ \text { T3 } & \text { Triiodotironina } \\ \text { TAB } & \text { Tecido adiposo branco } \\ \text { TAM } & \text { Tecido adiposo marrom } \\ \text { TBT } & \text { Tributilestanho } \\ \text { TBTC } & \text { Cloreto de tributilestanho } \\ \text { TNF } \alpha & \text { Fator de necrose } \alpha \\ \text { TPT } & \text { Trifenilestanho } \\ \text { TR } & \text { Receptor do hormônio tireoidiano } \\ \text { TZD } & \text { Tiazolidinadiona } \\ \text { UV } & \text { Luz ultravioleta } \\ \text { WC } & \text { Circunferência da cintura } \\ \end{array}$


1 INTRODUÇÃO

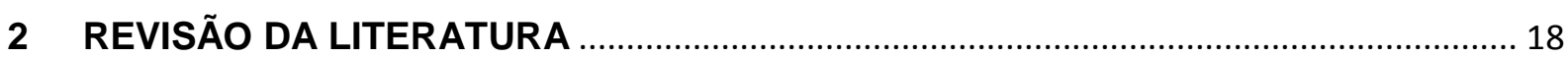

2.1 DESREGULADORES ENDÓCRINOS …………………….......................................... 18

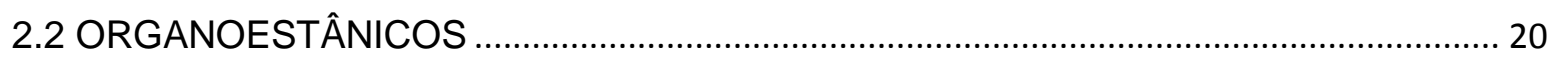

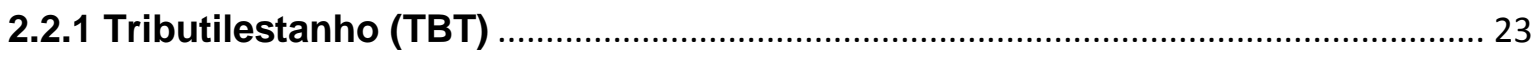

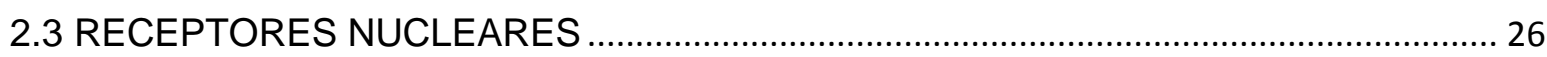

2.3.1 Receptores Ativados por Proliferador de Peroxissoma (PPAR) ………….. 27

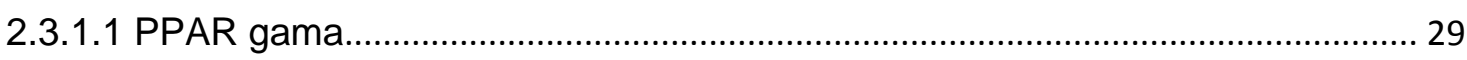

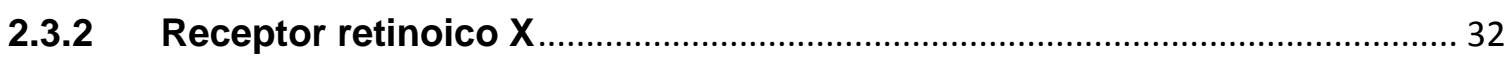

2.3.3 Tributilestanho (TBT) e Receptores Ativados por Proliferador de Peroxissoma gama (PPARY) ………………………………………………………....... 34

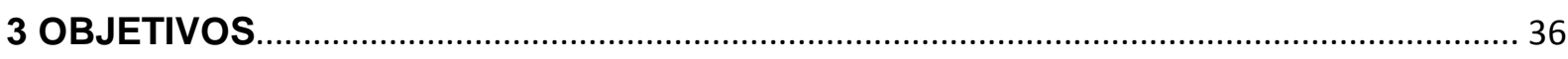

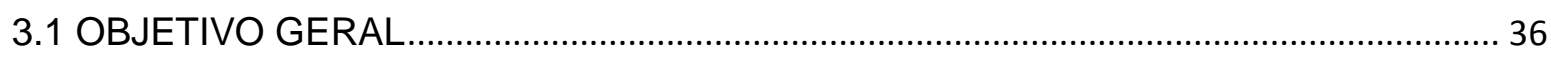

Estudar o efeito do TBTC sobre variáveis metabólicas e perfil glicolipídico de camundongos C57BI/6 submetidos à dieta normolipídica ou hiperlipídica. ........................... 36

3.2 OBJETIVOS ESPECÍFICOS.................................................................................... 36

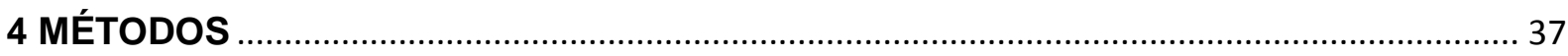

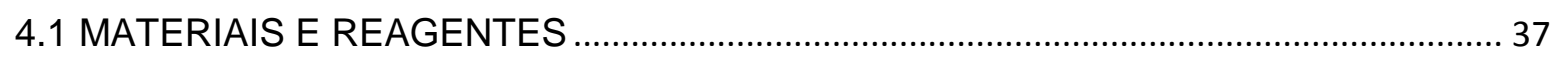

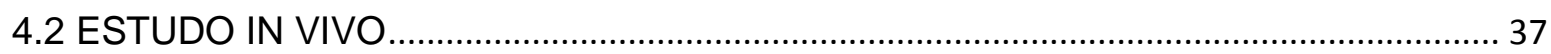

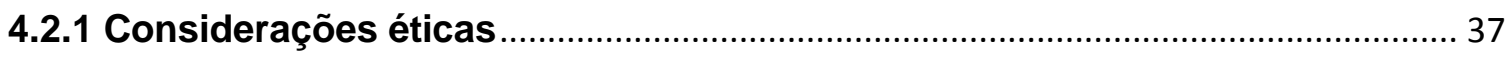

4.2.2 Modelo animal e dieta ………………………………………………………........ 38

4.2.3 Delineamento experimental .................................................................................. 38

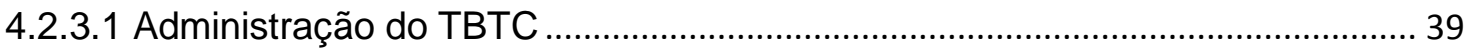

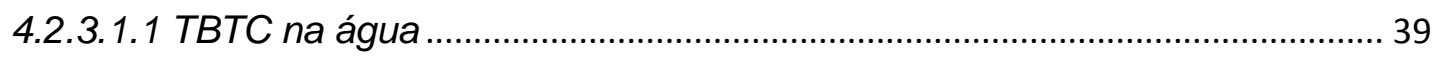

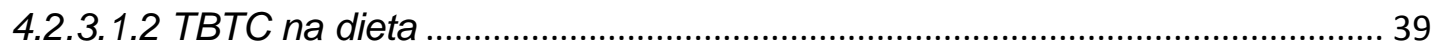

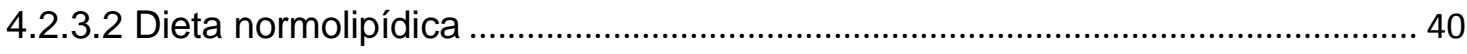

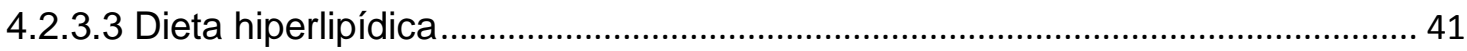

4.2.4 Avaliação da massa corporal, consumo de dieta, ingestão hídrica e glicemia

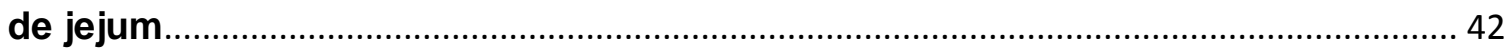

4.2.5 Eutanásia e coleta de sangue e tecidos ......................................................... 42

4.2.6 Processamento dos tecidos para análise histológica........................................ 43

4.2.6.1 Fixação de tecidos ....................................................................................... 43

4.2.6.2 Desidratação, diafanização e inclusão em parafina ............................................ 43 


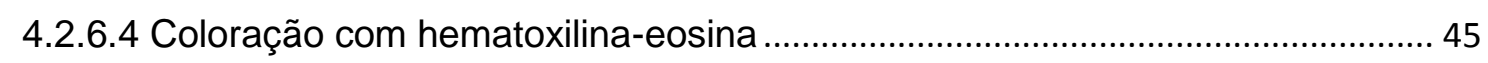

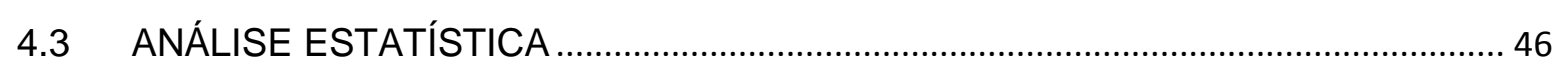

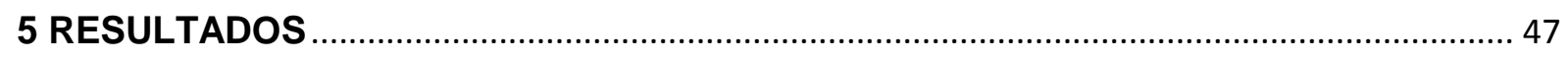

5.1 AVALIAÇÃO DA MASSA CORPORAL DOS ANIMAIS ALIMENTADOS COM DIETA NORMOLIPÍDICA E TRATADOS COM TBTC .................................................................... 47

5.2 AVALIAÇÃO DA INGESTÃO DE DIETA E INGESTÃO HÍDRICA DOS ANIMAIS

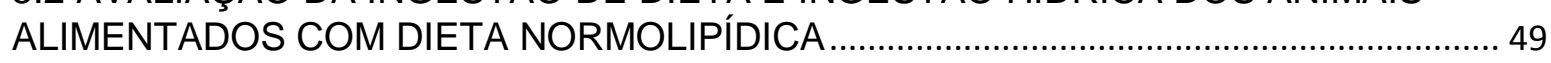

5.3 AVALIAÇÃO DA GLICEMIA EM JEJUM DOS ANIMAIS ALIMENTADOS COM DIETA NORMOLIPÍDICA... 51

5.4 AVALIAÇÃO DA MASSA DOS TECIDOS ADIPOSOS E ÓRGÃOS DOS ANIMAIS ALIMENTADOS COM A DIETA NORMOLIPÍDICA 52

5.5 AVALIAÇÃO DA MASSA CORPORAL DOS ANIMAIS TRATADOS COM TBTC E ALIMENTADOS COM DIETA HIPERLIPÍDICA 54

5.6 AVALIAÇÃO DA INGESTÃO DE DIETA E INGESTÃO HÍDRICA DOS ANIMAIS ALIMENTADOS COM A DIETA HIPERLIPÍDICA 56

5.7 AVALIAÇÃO DA GLICEMIA EM JEJUM DOS ANIMAIS ALIMENTADOS COM A DIETA HIPERLIPÍDICA.. 59

5.8 AVALIAÇÃO DA MASSA DOS TECIDOS ADIPOSOS E ÓRGÃOS DOS ANIMAIS ALIMENTADOS COM DIETA HIPERLIPÍDICA..

5.9 AVALIAÇÃO DAS CARACTERÍSTICAS HISTOLÓGICAS DO TECIDO ADIPOSO DOS ANIMAIS ALIMENTADOS COM DIETA HIPERLIPÍDICA .

5.10 AVALIAÇÃO DAS CARACTERÍSTICAS HISTOLÓGICAS DO TECIDO HEPÁTICO DOS ANIMAIS ALIMENTADOS COM DIETA HIPERLIPÍDICA.. 68

6 DISCUSSÃO 69

7 CONCLUSÃO. 74

8 REFERÊNCIAS. 75

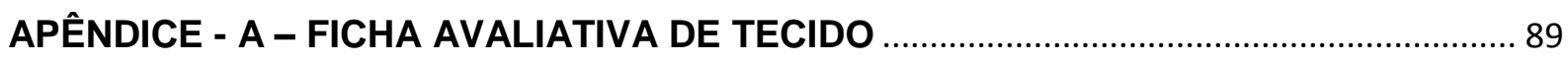

ANEXO A - APROVAÇÃO DA COMISSÃO DE ÉTICA NO USO ANIMAL ........................... 90

ANEXO B - APROVAÇÃO DA COMISSÃO DE ÉTICA NO USO ANIMAL (ADENDO) ...... 91

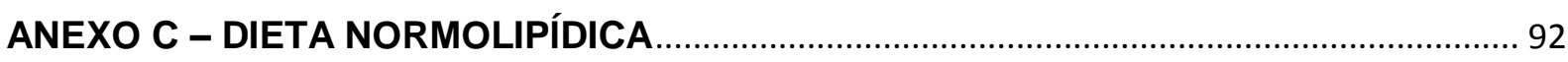

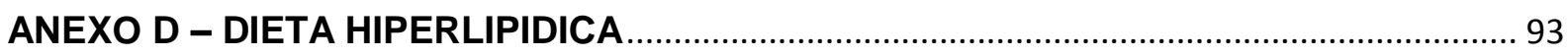




\section{INTRODUÇÃO}

Os efeitos dos poluentes ambientais sobre a saúde humana e de outros animais é uma grande preocupação mundial. Estima-se que a produção global de compostos químicos sintéticos tenha aumentado de 1 milhão para 400 milhões de toneladas entre a década de 1930 e os dias atuais (1). Estas substâncias, em sua maioria, apresentam influência ainda desconhecida sobre os sistemas biológicos, porém várias de suas propriedades como lipossolubilidade, estabilidade química, toxicidade, persistência e bioacumulação as tornam potenciais fontes de danos aos organismos vivos, mesmo em baixas concentrações $(2,3)$.

Estudos recentes mostram que muitos destes compostos considerados poluentes ambientais agem como desreguladores endócrinos, os quais correspondem a qualquer substância que estimula ou diminui o efeito de ações hormonais (4-6).

As primeiras evidências da relação entre o aumento do nível de certas substâncias químicas no ambiente e o aumento da incidência da obesidade surgiram há pouco mais de uma década (7). Desde então, vários estudos foram realizados mostrando que uma série de compostos químicos são capazes de induzir a adipogênese e contribuir para o desenvolvimento da obesidade, dislipidemia, resistência à insulina e diabetes tanto em modelos animais $(8,9)$ quanto em humanos $(10-12)$.

Entre os poluentes ambientais mais amplamente distribuídos na natureza estão os organoestânicos $(13,14)$. Esses compostos são formados por um átomo de estanho diretamente ligado a um determinado número de grupos orgânicos e, dependendo do número destes, são denominados tri, di ou monoestanhos (13).

Entre os organoestânicos, o mais estudado é o cloreto de tributilestanho (TBTC) (15), utilizado principalmente na fabricação do PVC e que possui efeito obesogênico e indutor da resistência à insulina e diabetes (16-18).

O mecanismo pelo qual o TBT induz a adipogênese é a ativação do receptor nuclear ativado por proliferadores peroxissomais gama (PPARY), regulador chave da diferenciação e função do tecido adiposo branco $(\operatorname{TAB})(17,19)$, embora o efeito PPARy independente também já tenha sido demonstrado $(18,20)$. 
Dentre os compostos de TBT, um dos mais utilizados é o cloreto de tributilestanho (TBTC), muito usado como agente dessecante em vários tipos de indústria e que tem apresentado uma importante contaminação ambiental (21).

Nesta dissertação foi avaliado como o cloreto de tributilestanho (TBTC) influencia no metabolismo de camundongos $\mathrm{C} 57 \mathrm{BI} / 6$, quando alimentados com dieta normolipídica ou hiperlipídica. 


\section{REVISÃO DA LITERATURA}

\subsection{DESREGULADORES ENDÓCRINOS}

Os desreguladores endócrinos (DE) são compostos exógenos que causam efeitos adversos no sistema hormonal de seres humanos e de outros animais (22). No meio ambiente, mesmo em concentrações baixas acabam exercendo efeitos deletérios na saúde da população em geral (23).

Os mecanismos envolvidos nesses efeitos são diversos, incluindo modificação na síntese, liberação, transporte, metabolismo, ligação, ação ou eliminação de hormônios naturais responsáveis pela manutenção da homeostase e pela regulação de processos de desenvolvimento (23).

Os DE abrangem muitas classes de produtos químicos, hormônios sintéticos, constituintes vegetais, pesticidas, vários compostos utilizados na indústria de plásticos e nos produtos de consumo, subprodutos industriais e principalmente poluentes. Muitas vezes são amplamente dispersos no ambiente. Alguns são persistentes, permanecem por um longo tempo no meio ambiente, sem sofrer degradação, sendo por esse motivo denominados poluentes orgânicos persistentes (POPs)(24).

Alguns desses DE estão sendo implicados na fisiopatogênese da obesidade. Uma grande lista de poluentes químicos está sendo investigada como envolvidos na epidemia de obesidade que acomete todo o mundo. Alguns exemplos de poluentes químicos relacionados com obesidade humana incluem os organoclorados persistentes (bifenil policlorado - PCB, diclorodifenildicloroetileno - DDE, hexaclorobenzeno - $\mathrm{HCB}$, betaexaclorocicloexano $\mathrm{\beta HCH}$, oxiclordano - $\mathrm{OC}$, dibenzodioxinas policloradas - PCDD e dibenzofuranos policlorados - PCDF), bifenil polibromado semipersistente, e os ftalatos não persistentes e bisfenol A - BPA (25).

A exposição aos DE pode ocorrer por meio da dieta, ar, pele e água, visto que esses desreguladores podem estar presentes nos alimentos e bebidas que as pessoas consomem, medicamentos administrados, pesticidas utilizados na 
agricultura e cosméticos que são utilizados (26) A Figura 1 ilustra as principais fontes de exposição humana aos DE.

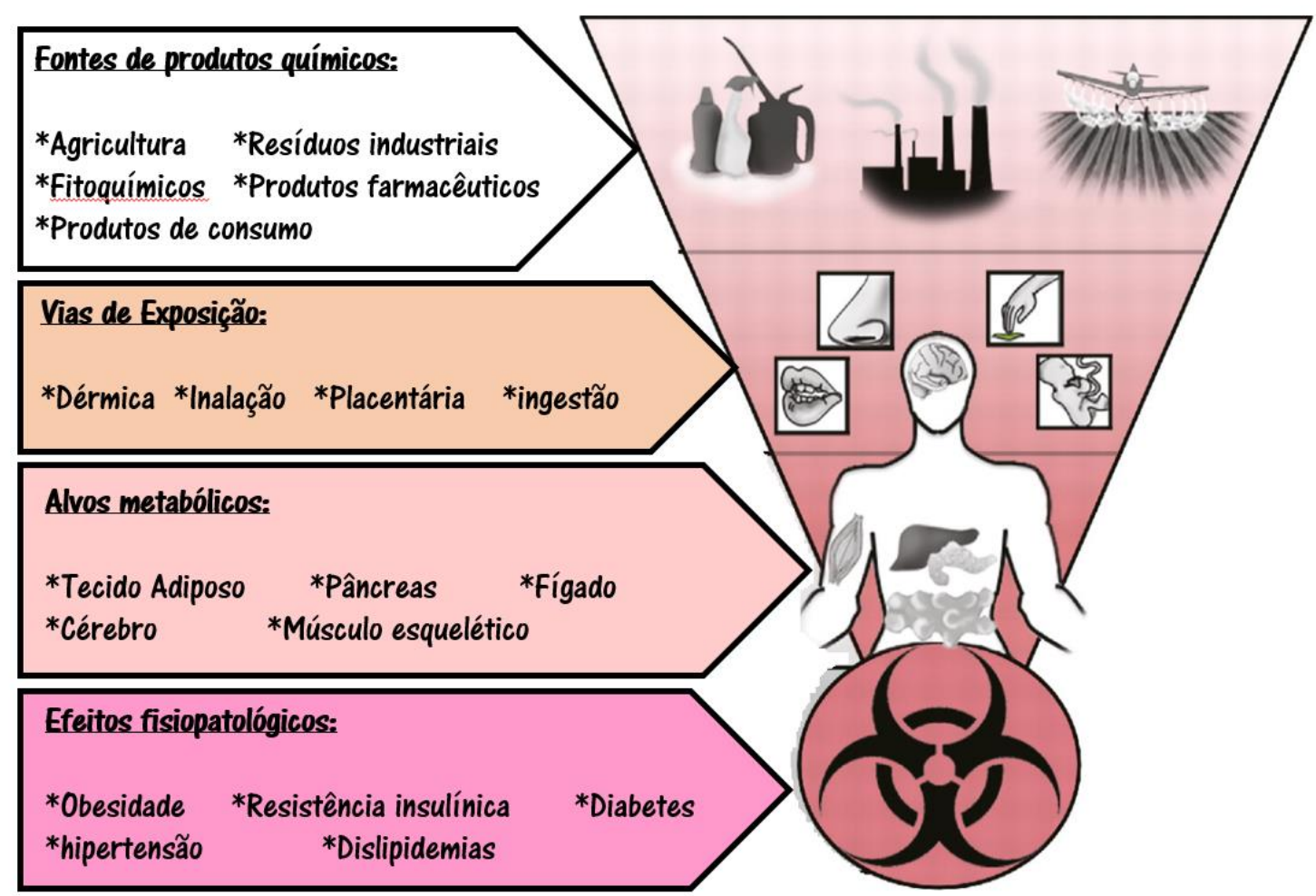

Figura 1. Fontes, vias de exposição, alvos metabólicos e efeitos fisiopatológicos de desreguladores endócrinos. Adaptado de (27)

A primeira associação entre contaminantes ambientais e o aumento da incidência de obesidade no mundo moderno foi proposto pelo estudo de BaillieHamilton em 2002. Seus resultados mostraram uma correlação positiva entre 0 aumento na quantidade de produtos químicos lançados no meio ambiente e crescimento da obesidade nos Estados Unidos da América (7). Posteriormente, em 2009 e 2010, outros estudos também associaram o ganho de massa corporal e exposição a DE (28-30) inclusive estudos experimentais sugerem que a exposição de roedores a alguns DE como bisfenois, organoestânicos e ftalatos são capazes de induzir um aumento da massa corporal (31-34).

Um dos grupos de pesquisadores que vem se destacando na investigação da importância dos DE no desenvolvimento da obesidade é o do Prof. Bruce Blumberg da Universidade da Califórnia em Irvine. Seus estudos chamam a atenção para os 
efeitos obesogênicos dos compostos organoestânicos, classificados como poluentes orgânicos persistentes (POP) e, denominados por Blumberg como obesogênicos ambientais $(4,16,17,32,35-37)$.

Além desses compostos estarem relacionados com a obesidade, há também uma preocupação quanto à associação dos DE com alguns distúrbios metabólicos, incluindo diabetes tipo 2, síndrome metabólica, doenças cardiovasculares e até algumas formas de câncer $(5,6,38,39)$.

\subsection{ORGANOESTÂNICOS}

Os organoestânicos são substâncias compostas por um átomo de estanho ligado diretamente a um ou mais grupos orgânicos (13). Eles estão entre os químicos ambientais mais amplamente distribuídos (13) (14), havendo mais de 800 organoestânicos conhecidos (40). Ao combinar-se com cloro, enxofre ou oxigênio são formados compostos inorgânicos, utilizados para pastas de dente, perfumes, sabão, agentes colorizadores, aditivos de comida e tintas, entre outros produtos (41).

Esses compostos podem apresentar uma ou mais ligações estanho-carbono,

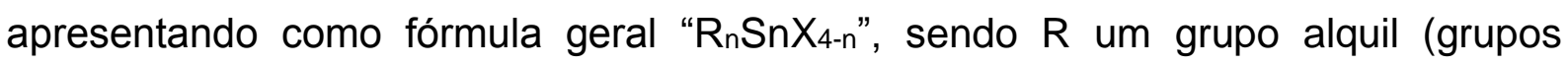
funcionais monovalentes derivados dos alcanos ou cicloalcanos) ou aril (grupo funcional monovalente derivado de um anel aromático), e X um ânion, tal como cloreto, óxido, hidróxido ou outro grupo funcional, o n pode variar de 1 a 4 (42).

O número de ligações Sn-C apresenta uma grande importância nas propriedades dos organoestânicos, levando a uma variedade enorme de aplicações. Os compostos mono-organoestânicos $(n=1)$ tem baixa toxicidade, e o seu uso é para agentes a prova d'água, para materiais celulósicos, assim como retardantes de fogo para tecidos de lã (43). Tanto os mono $(n=1)$ quanto os dissubstituídos $(n=2)$ são utilizados como estabilizadores de PVC e precursor do filme de óxido de estanho utilizado em vidro. Os compostos dissubstituídos tem alto poder estabilizante para o PVC, conferindo maior resistência à luz e ao calor (42). 
Os compostos trissubstítuídos $(n=3)$ são os que apresentam a máxima atividade biológica, tendo importância como biocidas, e os mais conhecidos são os tributilestanho (TBT) e o trifenilestanho (fungicida e anti-incrustante) (43).

Os compostos tetrassubstituídos ( $n=4)$ por sua vez, não apresentam atividade biológica significativa, sendo usados como intermediários nas sínteses químicas, e utilizados na aplicação comercial como precursores para outros compostos organoestânicos (13).

A degradação dos compostos organoestânicos ocorre por meio da redução dos grupos funcionais $R$, com a desbutilação/desfenilação, conforme apresentado na Figura 2. Dessa forma, ocorre a transformação do tri(butil/fenil) estanho a di(butil/fenil) estanho, e na sequência para mono(butil/fenil)estanho, chegando à redução final a estanho inorgânico. Os principais fatores atuantes nessa transformação são os fatores abióticos como a radiação UV, radiação gama e temperatura e os fatores bióticos como a biodegradação bacteriana (44).

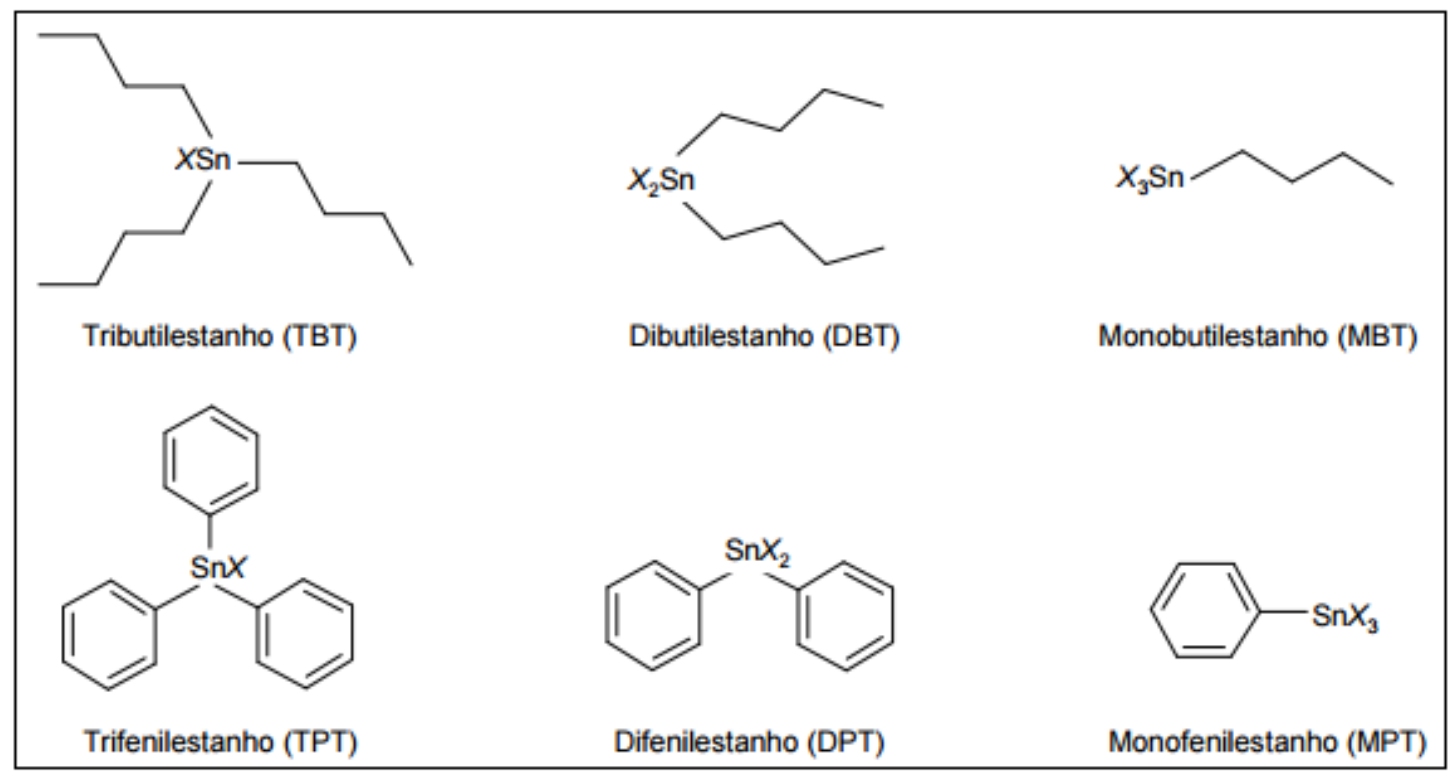

Figura 2. Tributilestanho e trifenilestanho e seus respectivos produtos de desbutilação e desfenilação. $\mathrm{X}=$ espécie aniônica (ex. cloreto, óxido, hidróxido) (45).

Conforme referido anteriormente, os compostos organoestânicos são utilizados em uma grande variedade de indústrias, provocando assim um grande impacto sobre 
o meio ambiente. A Figura 3 mostra esquematicamente as vias pelas quais os organoestânicos entram no meio ambiente, associados ao seu uso comercial (42).

As formas como os organoestânicos podem entrar no organismo são por meio da ingestão, inalação ou contato dérmico. O trimetilestanho, de cadeia orgânica curta, por exemplo, apresenta alta toxicidade e tem boa absorção pelo trato gastrointestinal (14). A excreção varia de acordo com o composto orgânico, mas geralmente ocorre predominantemente através das fezes (46). A presença de organoestânicos no homem foi demonstrada na urina de indivíduos que estavam altamente expostos a esses compostos (47). Também foram encontrados organoestânicos no sangue total de pescadores finlandeses e suas familias, que foi associado ao consumo de peixe contaminado com organoestânicos. (48) 

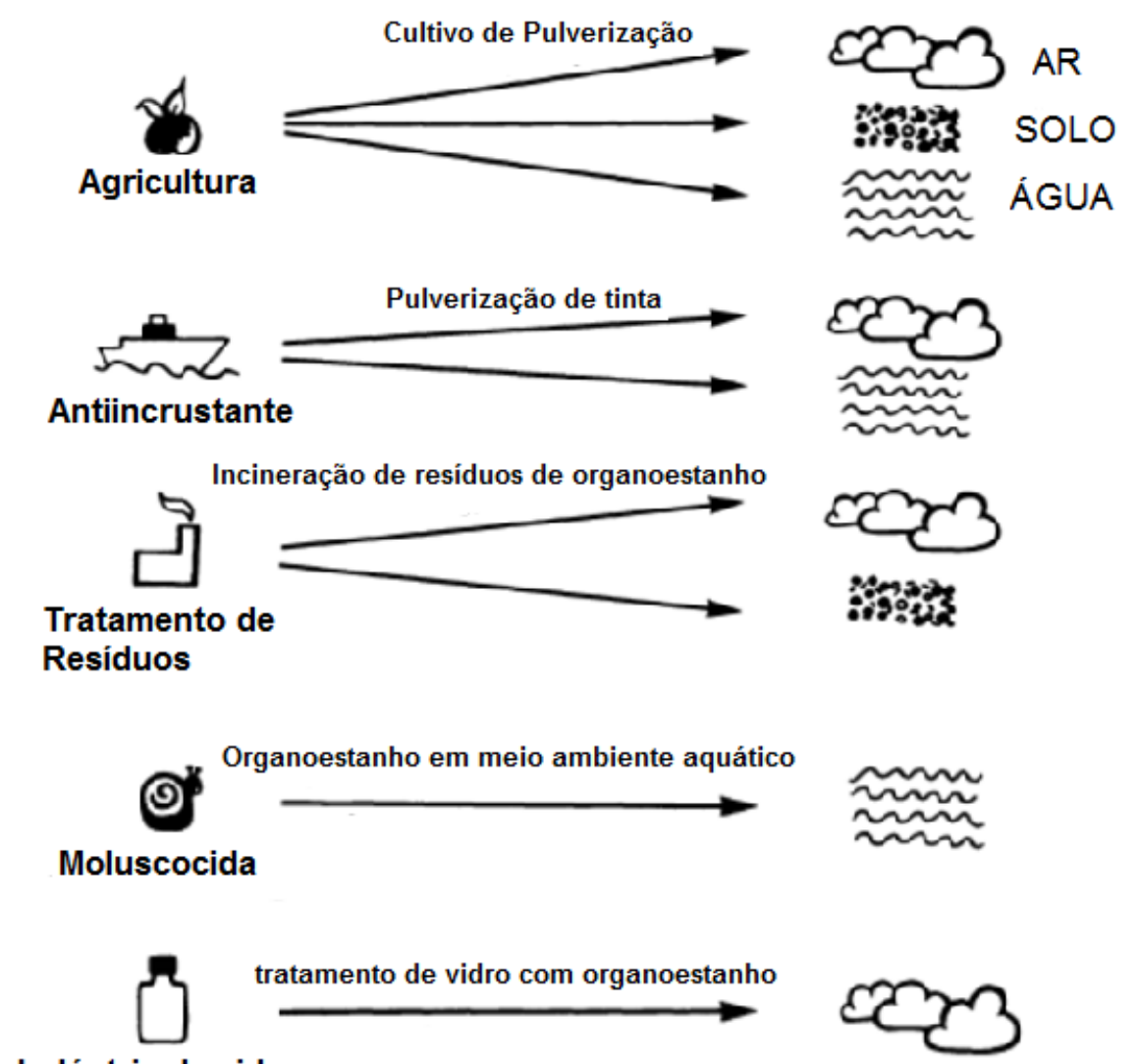

Indústria de vidro

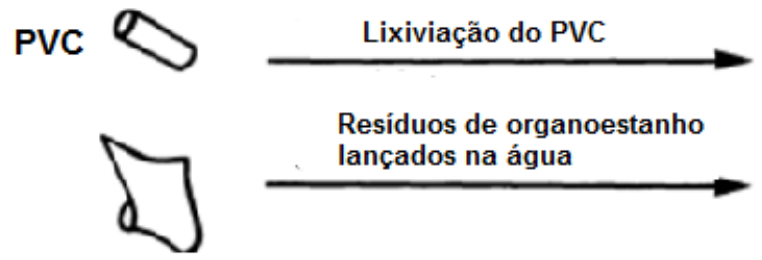

Fabricação de Papel

Figura 3. Possíveis meios de entrada de compostos organoestânicos no ambiente. Adaptado de (42)

\subsubsection{Tributilestanho (TBT)}

O comprometimento do meio ambiente pela presença do TBT começou a ser identificado em 1976 quando foi descrito que a presença de partículas inorgânicas na água estaria envolvida no desaparecimento de ostras na costa da Inglaterra. Dez anos depois, em 1987, Gibbs et al., observaram que esse fenômeno estava sendo causado 
pela contaminação dessas águas pelo TBT, que era usado como pintura antiincrustante dos barcos, extremamente eficaz e relativamente econômico na década de $70(49,50)$.

O mecanismo pelo qual o TBT promoveu o desaparecimento das ostras foi descoberto posteriormente, quando foi mostrado que o TBT interfere na diferenciação morfofisiológica sexual de gastrópodes, favorecendo o desenvolvimento de caracteres sexuais masculinos, tais como pênis e canal deferente em fêmeas, impedindo a reprodução das espécies, esse fenômeno foi denominado de imposex (51-53).

Baixas concentrações de TBT ( $<0,5 \mathrm{ng} \mathrm{Sn} / \mathrm{L})$ para o molusco Nucella lapillus, foram suficientes para iniciar o processo do imposex, enquanto concentrações maiores do que 2 ng Sn/L causaram má formação do sistema genital feminino, levando à interrupção hormonal e posterior falência reprodutiva, e a longo prazo, poderia levar a sua extinção, devido à ausência da reprodução (53). O mecanismo pelo qual o TBT induz o imposex está associado ao aumento na concentração da testosterona causado pela inibição da citocromo P-450 aromatase, enzima responsável pela conversão da testosterona em estradiol-17ß $(54,55)$.

À medida que foram compreendidas as propriedades dos compostos organoestânicos, aumentaram os estudos mostrando a associação do seu uso e a diminuição das espécies marinhas (51). Assim, a proibição do seu uso foi iniciada em 1982 na França, em 1987 no Reino Unido e mundialmente, entre o final dos anos 80 e início dos anos 90.

A Organização Marítima Internacional (IMO), devido à elevada toxicidade do TBT, recomendou a proibição global do uso de compostos organoestânicos como pintura anti-incrustante, no início de janeiro de 2003, com o objetivo de estabelecer o banimento completo até janeiro de 2008 (56). Nos EUA, a Agência Federal de Administração em Segurança e Saúde Ocupacional estabeleceu o limite para exposição ocupacional, de $0,1 \mathrm{mg} / \mathrm{m}^{3}$ de $\operatorname{ar}(41)$. No Brasil, o Conselho Nacional do Meio Ambiente (CONAMA) publicou uma resolução em 2005 que estabelece níveis máximos de TBT permitidos nas águas, sendo $0,063 \mu \mathrm{g} / \mathrm{L}$ nas águas doces destinadas ao consumo humano, 2,0 $\mathrm{\mu g} / \mathrm{L}$ nas destinadas à pesca ou cultivo de organismos para fins de consumo, 0,01 $\mu \mathrm{g} / \mathrm{L}$ nas águas salinas destinadas à recreação de contato primário e pesca e $0,37 \mu \mathrm{g} / \mathrm{L}$ nas destinadas à navegação e pesca (57). 
O TBT também tem sido associado ao ganho de massa corporal. Estudos in vitro e em roedores sugerem que o TBT modifica a programação metabólica possuindo um efeito obesogênico assim como também pode interefir no apetite. Em ratos fêmeas, a exposição ao TBT ocasionou um aumentou na ingestão de alimentos mas não houve aumento da massa corporal, divergentemente, os ratos machos expostos ao TBT não tiveram aumento na ingestão de alimentos mas tiveram aumento de massa corporal (58). Em camundongos, foi relatado que o TBT pode resultar em obesidade e esteatose hepática, induzir a ocorrência de resistência à insulina e à leptina (34).

Estudos mostraram que o TBT pode promover o acúmulo de lipídios no modelo de células murina 3T3-L1, perturbando os reguladores chaves da adipogênese $(15,32)$. Ensaios de diferenciação em adipócitos, na presença de coquetel indutor adipogênico [insulina, dexametasona e isobutilmetilxantina (IBMX)], e marcados com a coloração óleo vermelho $O$, mostraram que o TBT induziu o acúmulo de lipídios semelhante à rosiglitazona (17) e troglitazona (59).

É interessante observar que os efeitos mais significativos do TBT foram melhor evidenciados em estudos transgeracionais (transmissão das alterações às gerações seguintes) (60-62). Animais que foram expostos ao TBT no período prénatal transmitiram efeitos de adipogênese aos seus descendentes. Chamorro-García et al., 2013, trataram camundongos fêmeas grávidas com TBT na água de beber e observaram que, os camundongos das 3 gerações subsequentes (F1, F2 e F3) obtiveram aumentos consideráveis na massa adiposa branca e também no tamanho e número de adipócitos (16).

Enquanto existem estudos que relacionam a presença de outros desreguladores, como ftalatos, no organismo humano e a obesidade, mostrando uma associação positiva entre a presença do desregulador na urina e maiores Índices de Massa Corporal (IMC) e Circunferência da Cintura (WC) (63), não foram encontradas referências que relacionam TBT em níveis plasmáticos, séricos e urinários com a obesidade humana.

Um dos mecanismos propostos para o efeito obesogênico do TBT é seu efeito agonista sobre o receptor activado por proliferador de peroxissoma gama (PPARY) e do seu parceiro de heterodimerização, o receptor retinoide $X(R X R)(17,19,36,64-$ 66). 


\subsection{RECEPTORES NUCLEARES}

Os receptores nucleares (RN) são uma classe de proteínas encontradas nas células que atuam no núcleo regulando a transcrição gênica e consequentemente a homeostase, reprodução, desenvolvimento e metabolismo. Eles possuem a capacidade de ligar-se ao DNA funcionando como fatores de transcrição ativados por ligante (67). Quando o ligante acopla-se ao receptor, induz neste uma mudança conformacional que modula a atividade transcricional. Esses ligantes são moléculas hidrofóbicas que podem ser derivados de retinoides, ácidos graxos, colesterol, hormônios e vitaminas lipofílicas, bem como os antibióticos, xenobióticos e drogas sintéticas (68).

Os receptores nucleares apresentam uma estrutura primária dividida basicamente em cinco regiões que estão esquematizadas na Figura 4. A região amino-terminal ou A/B é a região mais variável entre os $\mathrm{RN}$ e contém um domínio de ativação independente do ligante chamado de AF-1, seu tamanho também é variável, desde menos de 50 a mais de 500 aminoácidos. A regiao C, mais conservada, é composta pelo DBD (DNA-binding domain) que é responsável pela especificidade de ligação do receptor ao DNA e podem ser chamadas de "dedos de zinco". Entre os dominios $\mathrm{C}$ e $\mathrm{E}$, encontra-se uma região menos conservada (domínio D) que se comporta como uma articulação flexível promovendo o efeito de dobradiça no receptor. A região do carboxi-terminal (dominio E) contém o LDB (ligand-binding domain) que é responsável por muitas funções, principalmente induzidas pelo ligante, nomeadamente a AF-2 tem a função de transativação. Os RN podem ou não conter uma última região denominada domínio $F$, cuja sequência é extremamente variável e a função é desconhecida $(67,69)$. 


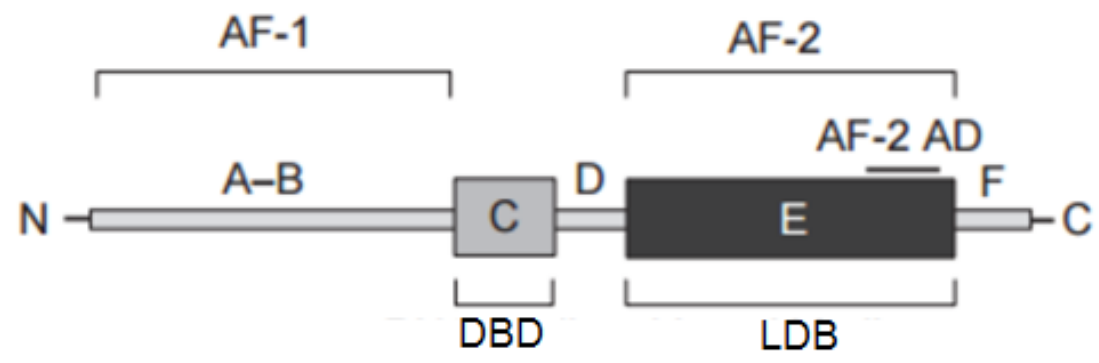

Figura 4. Organização estrutural e funcional dos receptores nucleares. A região N-terminal de A-B tem a função de transativação denominada AF-1. O domínio de ligação ao DNA (DBD; região C) é a região mais conservada do domínio e codifica dois módulos de dedo de zinco. O domínio de ligação ao ligante (LBD; região E) é menos conservada e medeia a ligação do ligante. A região $D$ é considerado como uma dobradiça. A região $F$ não está presente em todos os receptores e a sua função é desconhecida. Adaptado de (69)

\subsubsection{Receptores Ativados por Proliferador de Peroxissoma (PPAR)}

Os receptores ativados por proliferador de peroxissoma (PPARs) pertencem à superfamília de RN. Os PPARs são dependentes de fatores de transcrição que regulam a expressão do gene-alvo. Cada receptor liga-se ao DNA em seu elemento responsivo ao PPAR (PPRE) que é uma região regulatória ou promotora de genesalvos. Ao ligar-se ao DNA para regular a transcrição, o PPAR dimeriza-se com o receptor retinoide X (RXR) (70). O heterodímero PPAR e RXR ligado ao DNA recruta coativadores ou moléculas/complexos correpressores promovendo a ativação ou repressão da transcrição gênica (71). 


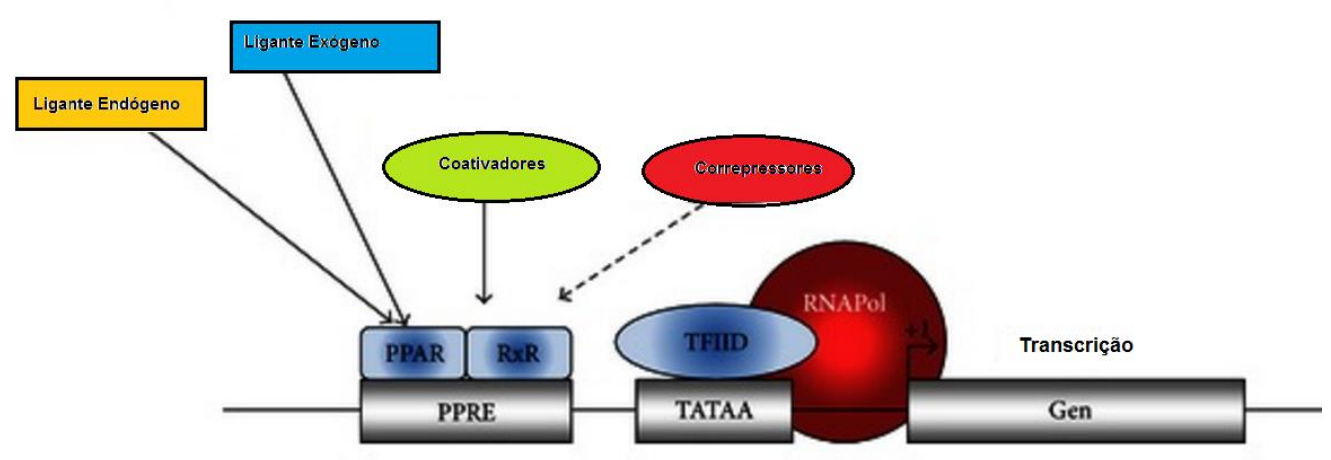

Figura 5. Mecanismos de transcrição genética de PPAR. No estado inativado, PPAR interage com o correpressor, inibindo assim o processo de transcrição. Depois da ligação do ligante exógeno (fármaco) ou ligante endógeno (ácidos graxos, prostaglandinas, etc.) com o PPAR, este é ativado e heterodimeriza com RXR e recruta coativadores facilitando a transcrição de vários genes. Adaptado de (72).

Foram identificadas três isoformas, PPARY, PPARa e PPARס que são transcritas por genes distintos. Essas isoformas da família PPAR, estão claramente envolvidas na regulação sistêmica do metabolismo lipídico e atuam como "sensores" para ácidos graxos. Estes receptores regulam um amplo conjunto de genes de forma coordenada $(70,73)$.

O receptor- $\alpha$ ativado por proliferador de peroxissoma (PPAR $\alpha$ ) foi o primeiro sensor genético para gorduras e foi identificado em 1990, devido à sua capacidade de ligar substâncias químicas conhecidas por induzir proliferação do peroxissoma. Estas organelas contribuem para a oxidação de ácidos graxos, e sua proliferação pode resultar em hepatomegalia e carcinogênese em roedores (74). Como alvo terapêutico, evidências experimentais sugerem que a ativação de PPARa atenua ou inibe vários mediadores de danos vasculares, incluindo lipotoxicidade, inflamação, geração de espécies reativas de oxigênio, disfunção endotelial, angiogênese e trombose e, portanto, pode influenciar as vias de sinalização intracelular que levam a complicações microvasculares (75).

O receptor - $\delta$ ativado por proliferador de peroxissoma (PPARס) também denominado PPAR $\beta$ ou PPAR $\beta$, $\delta$, é a principal isoforma de PPAR no músculo esquelético e um importante regulador do metabolismo de ácidos graxos (76). É 
expresso em diversos tecidos, inclusive em células adiposas e endoteliais (77). $\mathrm{O}$ PPARס está envolvido em diversos processos biológicos, como o metabolismo de lipídios e glicose, diferenciação celular, proliferação e apoptose, regulação imune, e tumorigênese (77).

Os receptores - $\mathrm{y}$ ativados por proliferador de peroxissoma (PPARY) regulam genes importantes na diferenciação e vários processos metabólicos, especialmente a homeostase de glicose (70). O PPARy é expresso no tecido adiposo branco e marrom, o intestino grosso e baço. Sendo sua expressão mais alta nos adipócitos, ele desempenha um papel fundamental na regulação da adipogênese, do balanço energético e biossíntese de lipídios (78).

\subsubsection{PPAR gama}

O PPAR-y é o regulador principal do armazenamento de lípidos no tecido adiposo onde também promove a diferenciação de adipócitos, detectando a disponibilidade de lipídios e adaptando programas de expressão gênica apropriados. O gene do PPARy é transcrito em três RNAs mensageiros, PPARy1, PPARy2 e PPARy3. As proteínas produzidas a partir dos RNAs mensageiros de PPARy1 e PPARy3 são idênticas, enquanto o produto de PPARy2 contém 28 aminoácidos adicionais na região NH2-terminal (79). As duas isoformas de proteínas PPARY1 e PPARy2 foram detectados tanto em camundongos quanto em humanos. Em todos os tecidos analisados, PPARy2 foi muito menos abundante do que PPARy1 (80). A isoforma PPARy2 está mais expressa principalmente no tecido adiposo enquanto que a isoforma PPARy1 é expressa em quase todas as células $(79,81)$. Ambas as formas de PPARy1 e PPARy2 são essenciais para o desenvolvimento do tecido adiposo e o controle da sensibilidade à insulina (78). Já o PPARy3 foi expresso no tecido adiposo, no epitélio do cólon e macrófagos humanos (82).

O PPARy pode regular a síntese de ácidos graxos por diferentes mecanismos. Um mecanismo dá-se pelo controle da expressão de enzimas lipogênicas tais como dessaturase 1 estearoil-CoA. Além disso, PPARy promove a esterificação de ácidos graxos em triglicerídeos por regulação direta do promotor de glicerol quinase. 0 
PPARy também regula a expressão de proteínas da família perilipina, envolvidas na organização estrutural de gotículas lipídicas (79).

O PPARy é essencial para que ocorra a diferenciação de adipócitos tanto in vitro como in vivo $(83,84)$. In vitro, células 3T3- L1 (pré-adipócito murino não diferenciado), foram tratadas com um coquetel indutor [insulina, dexametasona e isobutilmetilxantina (IBMX)] para promover a diferenciação e durante esse processo foi observado um aumento progressivo da expressão de PPARy. In vivo, foi analisada a expressão de PPARy em alguns tecidos de camundongos (baço, intestino, fígado, rim, coração, testículo, cérebro e adiposo branco) e uma expressão significativa foi encontrada apenas no tecido adiposo branco (85).

Confirmando a importância do PPARy no processo de adipogênese, Barak et al., 1999, mostraram que camundongos com mutação no locus do PPARy, apresentavam deficiência em todas as formas de tecido adiposo, caracterizando um quadro de lipodistrofia. A ausência de tecido adiposo em mutantes recém-nascidos comprometeu os processos fisiológicos orquestrados por PPARY e consequentemente a vida desses animais (86). Em humanos foi relatado 3 gerações de uma família canadense, em que os indivíduos que apresentavam lipodistrofia parcial, tinham mutação no gene PPARy enquanto que a mutação estava ausente nos membros normais da família (87). Outros trabalhos também associaram a mutação no gene do PPAR à lipodistrofia parcial $(88,89)$.

A adipogênese regulada por PPAR gama envolve a participação de outros fatores de transcrição como proteínas de ligação ao amplificador - alfa (C/EBPa) que é da familia CCAAT(citosina/citosina/adenosina/adenosina/timidina) (90). O PPARY em parceria com o C/EBPa, regulam a expressão de um complexo de genes que resulta no acúmulo de lipídeos contribuindo para o fenótipo do adipócito. Dentre estes genes, alguns exemplos são o glicerofosfato desidrogenase, ácido graxo sintase, acetil CoA carboxilase, enzima málica, Glut 4, o receptor de insulina e aP2 (a proteína de ligação a ácidos graxos que é seletiva de adipócitos). Ao decorrer deste processo, as gotas carregadas de lípidos começam a se acumular no citoplasma e tornam-se bastante grandes e, muitas vezes, se unem umas às outras (91).

Estudos com modelos de camundongos têm mostrado um papel de regulação do PPARy bem como C/EBPa, C/EBPß e C/EBPס do tecido adiposo in vivo. Camundongos transgênicos knockout para C/EBPa - / - , aos 7 dias de idade, 
apresentam ausência de gordura branca perirenal e epididimal. A ausência de tecido adiposo branco em muitos depósitos, mas com elevados níveis de lípidos séricos mostram que C/EBPa é necessária para o desenvolvimento in vivo deste tecido (92). Em outro estudo, camundongos transgênicos knockout para C/EBP - / - e C/EBPס - / - mas com a com expressão normal de C/EBPa e PPARy, mostraram sobrevivência de apenas $15 \%$. Contudo, os animais sobreviventes apresentaram a adipogênese prejudicada, mostrando que C/EBPa, C/EBP e C/EBPo têm um papel sinérgico na diferenciação terminal de adipócitos in vivo (93).

Ao contrário do receptor do hormônio tiroidiano (TR) que se liga especificamente à triiodotironina (T3) $(94,95)$, o PPARy liga-se a diferentes moléculas como derivados de ácidos graxos poli-insaturados de cadeia longa, como sensibilizadores de insulina (tiazolidinadiona, troglitazona, etc) (96) e outros compostos como prostaglandinas $(97,98)$. Contudo, o ligante endógeno com alta afinidade responsável pela regulação da atividade de PPARY não foi identificado (90). A capacidade do PPARy de ligar-se a diferentes compostos é explicada em parte por apresentar um bolso de ligação (binding pocket) maior que a grande maioria dos receptores nucleares (99).

Os agonistas de PPARy têm sido utilizados para o tratamento de pacientes com diabetes mellitus tipo 2 (96). Uma classe de compostos denominados tiazolidinadionas (TZDs), foi largamente utilizada e se mostrou eficaz no tratamento de diabetes mellitus tipo 2. Troglitazona, pioglitazona e rosiglitazona foram utilizadas para o controle glicêmico desses pacientes. Troglitazona e rosiglitazona foram retiradas do mercado em função dos efeitos adversos (100). A troglitazona por hepatotoxicidade e a rosiglitazona por apresentar risco cardiovascular (101).

Alguns mecanismos pelo qual agonistas de PPARy melhoram o controle do diabetes está relacionado principalmente ao aumento da sensibilidade à insulina. Essa sensibilidade pode ser por meio do aumento da expressão da adiponectina, que atua como sensibilizador, estimulando a oxidação de ácidos graxos em proteína quinase ativada por AMP (AMPK), como também pela inibição de alguns fatores como citocinas inflamatórias presentes no tecido adiposo como o fator de necrose a (TNFa) e interleucina-6 (IL-6) (102). Outro mecanismo pelo qual o PPARy ativado por agonistas melhora a sensibilidade insulínica, é o acúmulo dos ácidos graxos no tecido adiposo e diminuição da concentração plasmática e do transporte para o músculo. 
Como consequência dessa diminuição de ácidos graxos no músculo, tem-se a sensibilidade à insulina aumentada (103). Esses mecanismos de ação fazem com que o PPARy seja um alvo farmacológico no tratamento do diabetes.

Embora eficientes no aumento da sensibilidade insulínica, os agonistas totais de PPARy como as tiazolidinadionas (TZDs) apresentam efeitos colaterais como ganho de massa, edema e perda óssea, além do aumento do risco de mortalidade cardíaca, o que tornou necessária a busca por moduladores seletivos com efeitos secundários reduzidos (100).

Bruning e colaboradores mostraram que os compostos MRL-20, MRL-24, nTZDpa, SR145, SR147 e o BVT.13, em ensaios de transativação, comportaram-se como agonista parciais de PPARy (104). Outro composto sintético, o GQ-16 (5-(5bromo-2-metóxi-benzilideno)-3-(4-metil-benzil)tiazolidina-2,4-diona) mostrou atividade em PPARy. Amato et al., 2012, realizaram ensaios de transfecção e gene repórter, mostrando que o GQ-16 é um agonista específico e parcial de PPARy. Nesse mesmo estudo, em ensaios de diferenciação de adipócitos, o GQ-16 apresentou potencial adipogênico reduzido quando comparado à rosiglitazona, tanto em préadipócitos murinos (3T3-L1) quanto em células mesenquimais (C3H10T1/2) (105). In vivo, esses resultados foram confirmados por Coelho e colaboradores, que alimentaram camundongos com dieta hiperlipídica (60\% kcal de gordura) e trataram com veículo (Tween®-20 diluído em salina 0,25\%) rosiglitazona ( $4 \mathrm{mg} / \mathrm{kg} / \mathrm{d}$ ) ou GQ-16 $(40 \mathrm{mg} / \mathrm{kg} / \mathrm{d})$ por gavagem durante duas semanas. Ao final do tratamento, observaram que o GQ-16 reduziu o ganho de massa induzido pela dieta e a massa do tecido adiposo epididimal, a glicemia em jejum e os níveis de triglicerídeos no fígado (106). Esses dados sugerem que agonistas parciais de PPARy promovem a sensibilização à insulina sem os efeitos desfavoráveis que parecem estar associados ao agonismo completo.

\subsubsection{Receptor retinoico X}

Os receptores retinoico X (RXRs) são receptores nucleares que atuam como fatores de transcrição dependentes de ligantes (107). O RXR desempenha um papel 
central nas vias de sinalização reguladas por receptores nucleares, devido à sua parceria heterodímera obrigatória com quase um terço dos membros da família e além disso, os RXRs podem atuar como homodímeros (108).

O RXR tem a capacidade de heterodimerizar outros membros da superfamília de receptores nucleares, incluindo receptores de ácido retinóico (RAR), receptores do hormônio tireiodeano (TR), Receptores da vitamina D (VDR), Receptores ativados por proliferador de peroxissoma (PPAR), Receptores hepático X (LXRs), receptor farnesoide $X(F X R)$, receptor pregnano $X(P X R)$, e receptores androstanos constitutivos (CARs)(109). Essa habilidade do RXR de se heterodimerizar com diferentes receptores, denominou-se "receptor promíscuo" $(110,111)$.

O RXR pode ser codificado em três subtipos de proteína ( $R X R \alpha, \beta$ e y) sendo que cada uma destas é expressa durante o desenvolvimento, e no organismo adulto em padrões distintos. Foi mostrado também que o ácido retinóico 9-cis é um ligante de alta afinidade ao RXR. (112) Inclusive em 1990, Kliewer et al., mostraram que a exposição simultânea do ácido retinóico 9-cis a ambos os receptores (PPAR-RXR) resultavam em uma indução sinérgica da expressão gênica, fornecendo uma evidência do um papel fisiológico para o ácido retinóico 9-cis na modulação do metabolismo lipídico (113).

Na heterodimerização do RXR e PPAR, o receptor PPAR permite a ativação por ligantes específicos de RXR tornando-se um parceiro "permissivo". Essa interação forma uma base de sinalização para a transcrição que pode ser importante no controle de programas complexos de expressão gênica do PPAR (114). Porém, muitos outros receptores não esteróides também formam heterodímeros com $R X R$, e a análise estrutural atual sugere a possibilidade de muitos tipos diferentes de interação domíniodomínio tanto dentro de um único polipéptido como através dos parceiros heterodiméricos (115), dessa forma, apresenta um leque de possibilidades de mecanismos mediados pelo RXR.

Apesar dos retinóides (agonistas seletivos de RXR) terem sido estudado como como uma opção potencial para o tratamento da síndrome metabólica, podem provocar efeitos secundários indesejáveis tais como hipertriglicerimia e supressão do eixo do hormônio da tiróide (116). 
Foi demonstrado, em ensaios ex-vivo, que o TBT se ligava com alta afinidade ao LDB dos três subtipos de $\operatorname{RXR}$ ( $\alpha, \beta$ e y) (117). Outros estudos também demonstraram que o TBT é um agonista total de RXR sugerindo que os efeitos desse organoestânico pode ser mediado também por meio desse receptor $(19,32,118)$.

\subsubsection{Tributilestanho (TBT) e Receptores Ativados por Proliferador de Peroxissoma gama (PPARY)}

Estudos in vitro demonstraram que o TBT em concentração nanomolar (100 $\mathrm{nM})$ ativa o receptor PPARy. Ensaios de transativação e gene repórter realizados em células JEG-3 (células de coriocarcinoma) mostraram que o TBT ativou PPARy em dose dependente. A ativação do PPARy pelo TBT foi menor que a rosiglitazona, visto que o TBT ativou aproximadamente $38 \%$ da ativação da rosiglitazona (65). Nessa mesma concentração de TBT, Grum et al., 2006, em ensaio de transativação em células Cos7 (fibroblastos do rim de primata) encontraram a mesma ativação do TBT em torno de 30\% da ativação da troglitazona (32). Esses achados conferem ao TBT um caráter de agonista parcial, visto que sua ativação é menor quando comparada a agonistas totais de PPARy.

A ligação do TBT ao PPARy foi demonstrada em ensaios de cristalografia. Harada et al., 2015, utilizando cristalografia de raios $X$ e espectroscopia de massa em conjunto com ensaios de atividade apresentaram uma estrutura, na qual o TBT ligase no PPARy no sítio de ligação, o mesmo utilizado por outros agonistas totais. É interessante observar que o TBT faz uma ligação iônica, não-covalente, com o átomo de enxofre da cisteína (Cys 285) localizada na hélice 3 do PPARy. Diante disto, foram realizados ensaios de transativação utilizando as células JEG-3 com uma mutação no PPARy, onde a cisteína Cys285 foi substituída por alanina. A mutação C285A aboliu o efeito do TBT, mostrando que a interação específica entre o resíduo da cisteína e o átomo de estanho é essencial para a activação de PPARY por esse organoestânico (119). 
De forma semelhante aos agonistas de PPARY, o TBT também induz adipogênese em células 3T3 - L1. Células 3T3 - L1 foram tratadas com TBT em dois meios de diferenciação, um meio de diferenciação completo que incluía um coquetel indutor (IBMX, dexametasona e insulina) e um meio de diferenciação incompleto que não possuía IBMX e dexametasona. O acúmulo lipídico foi confirmado pela coloração com óleo vermelho O. O TBT em meio de diferenciação completo promoveu a diferenciação de adipócitos assim como a rosiglitasona, enquanto que no meio de diferenciação incompleto, a adição de TBT induziu a diferenciação adipocitária menor que a rosiglitasona, porém maior que o veículo. (118). Outro estudo utilizou a troglitazona como controle, que se mostrou um indutor fraco na ausência do coquetel indutor. Mesmo assim, os resultados com o TBT foram semelhantes, na ausência do coquetel indutor, o TBT promoveu uma maior diferenciação de adipócitos quando comparado ao veículo e na presença do coquetel indutor, promoveu diferenciação semelhante à da troglitazona (32).

No intuito de comprovar que o efeito adipogênico do TBT é dependente de PPARy, foram realizados ensaios em que células 3T3-L1 foram tratadas com um antagonista de PPARY (GW9662). Nesse contexto, tanto o TBT quanto a rosiglitazona mostraram reduzido potencial adipogênico, sugerindo que o TBT e a rosiglitazona exercem atividade adipogênica via ativação do PPARy (17).

Apesar de estar bem definido o efeito adipogênico do TBT em experimentos in vitro e ex-vivo e em animais expostos ao TBT in utero, o efeito direto do TBT na adipogênese de animais ainda é matéria controversa. He et al., em 2014 demostraram que ratos machos, mas não as fêmeas, quando tratados com TBT apresentaram aumento na massa corporal. Por outro lado, ao investigar a ingestão de alimentos, os resultados foram opostos ao ganho de massa, enquanto os animais machos tratados com TBT apresentaram menor ingestão de alimentos, as fêmeas tiveram aumento significativo da ingestão calórica (58). Em outro estudo, camundongos machos tratados com TBT apresentaram ganho de massa corporal associado a aumento dos níveis plasmáticos de insulina, resistina e leptina, sugerindo uma resistência à insulina. Contudo o mesmo estudo não descreveu presença de hiperglicemia, seja em jejum ou durante a sobrecarga de glicose (34). Considerando que o TBT é um agonista parcial de PPARy e total de RXR, poderíamos questionar se a exposição ao TBT ocasionaria uma sensibilização à insulina com um aumento na adipogênese, de forma 
semelhante ao que ocorre com outros agonista de PPARy. Nesse pressuposto, nosso trabalho visa investigar os efeitos diretos do TBT em camundongos submetidos à dieta normolipídica ou dieta hiperlipídica.

\section{OBJETIVOS}

\subsection{OBJETIVO GERAL}

Estudar o efeito do TBTC sobre variáveis metabólicas e perfil glicolipídico de camundongos C57BI/6 submetidos à dieta normolipídica ou hiperlipídica.

\subsection{OBJETIVOS ESPECÍFICOS}

- Investigar o efeito do TBTC sobre a massa corporal de camundongos C57BI/6.

- Investigar o efeito do TBTC sobre a tolerância à glicose e ingestão alimentar de camundongos $\mathrm{C} 57 \mathrm{BI} / 6$.

- Avaliar histologicamente os efeitos do TBTC sobre os tecidos adiposo marrom, branco inguinal e epididimal (visceral) de camundongos C57BI/6 alimentados com dieta hiperlipídica.

- Investigar os efeitos do TBTC sobre os tecido hepático avaliando a presença de esteatose em camundongos C57BI/6 alimentados com dieta hiperlipídica. 


\section{MÉTODOS}

\subsection{MATERIAIS E REAGENTES}

Rosiglitazona obtida da Cayman Chemicals (CAS [122320-73-4], EUA)

GQ-16 (5-(5-bromo-2-metóxi-benzilideno)-3-(4-metil-benzil) tiazolidina-2,4diona) cedido pelo Professor Ivan da Rocha Pitta da Universidade de Pernambuco Cloreto de tributilestanho TBTC (Cód. T50202, Sigma-Aldrich, Brasil). Isoflurano (BioChimico®)

Álcool etílico absoluto P.A. (CAS [64-17-5], Dinâmica, Brasil)

Xilol (CAS [1330-20-7], Dinâmica, Brasil)

Parafina (CAS [8012-95-1], Dinâmica, Brasil)

\subsection{ESTUDO IN VIVO}

\subsubsection{Considerações éticas}

Os experimentos propostos neste trabalho estão de acordo com os princípios éticos em experimentação animal e foram planejados seguindo a Legislação Brasileira (Lei Federal $n^{\circ} 11.794 / 2008$ ) e a Diretriz Brasileira para o cuidado e a utilização de animais para fins científicos (DBCA 2013) e foram aprovados pela Comissão de Ética no Uso Animal (CEUA) da Universidade de Brasília, UnbDoc número 141737/2013 adendo datado 24/02/2015. (Anexo A e B) 


\subsubsection{Modelo animal e dieta}

Neste trabalho, o modelo de estudo utilizado foi o camundongo Mus musculus da linhagem C57BI/6. Todos os indivíduos dessa linhagem são praticamente idênticos, devido a dezenas de gerações de consanguinidade (acasalamentos entre irmãos e irmãs) e são homozigóticos na maioria dos locus genéticos (120). Além disso, estudos demonstram que eles possuem predisposição para desenvolver diabetes e acúmulo de gordura e colesterol $(121,122)$, o que os torna um modelo adequado para os experimentos realizados nesta pesquisa.

Foram utilizados, no total, 41 camundongos machos, isogênicos, obtidos do Centro de Bioterismo da Faculdade de Medicina da Universidade de São Paulo. Durante todo o período do experimento, os animais foram mantidos em microisoladores, em estante ventilada (Alesco, SP, Brasil) com ar filtrado e temperatura constante de $25^{\circ} \mathrm{C}$ com ciclo claro/escuro a cada 12 horas (escuro entre 19:00 h e 7:00 h). A dieta e água fornecidas foram de livre acesso (ad libitum).

As dietas utilizadas foram fornecidas pela empresa Pragsoluções, SP (AIN93G) normolipídica (10\% do total de energia representados por lipídeos) e hiperlipídica (60\% do total de energia representados por lipídeos) (Anexo C e D).

\subsubsection{Delineamento experimental}

Nesse estudo avaliou-se o potencial efeito do TBTC em camundongos alimentados com dois diferentes tipos de dieta, normolipídica e hiperlipídica. As concentrações do TBTC utilizadas em ambos os casos, foram baseadas em estudos que utilizaram o mesmo composto. Enquanto, Penza et al., utilizaram fêmeas e machos de camundongos $C 57 B / / 6$, Zuo et al., 2011 utilizaram somente camundongos machos $\operatorname{KM}(34,123)$. 


\subsubsection{Administração do TBTC}

\subsection{TBTC na água}

A diluição do composto (TBTC) foi realizada no Laboratório de Farmacologia Molecular (FARMOL). Sabendo que o ganho de massa e a ingestão dos animais poderiam variar ao longo do tempo, foram realizados cálculos semanalmente, levando em consideração a massa corporal média dos animais e a ingestão de água naquele período. Para exemplificar, na 16 $6^{\underline{a}}$ semana, realizamos o cálculo de forma a obter a concentração de $1 \mu \mathrm{g}$ por quilo (massa do animal) por dia. Considerando a massa média do animal de $30 \mathrm{~g}$, cada animal deveria ingerir $0,030 \mu \mathrm{g}$ do TBTC por dia. Dado que cada animal consome em média $2,0 \mathrm{~mL}$ de água, a concentração de TBTC na água deveria ser de $0,015 \mu \mathrm{g} / \mathrm{mL}$. Para obter esta concentração foram realizadas diluições seriadas a partir de uma solução estoque. Para o cálculo das outras concentrações de TBTC 5 e $25 \mu \mathrm{g} / \mathrm{Kg}$ baseou-se na memória de cálculo utilizada para a concentração de TBTC $1 \mu \mathrm{g} / \mathrm{Kg}$, obtendo-se, respectivamente, a concentração de TBTC na água de 0,075 $\mu \mathrm{g} / \mathrm{mL}$ (TBTC $5 \mu \mathrm{g} / \mathrm{Kg}$ ) e 0,375 $\mu \mathrm{g} / \mathrm{mL}($ TBTC $25 \mu \mathrm{g} / \mathrm{Kg}$ ) a partir da solução estoque.

\subsection{TBTC na dieta}

A incorporação dos compostos (TBTC, rosiglitazona e GQ-16) à dieta foi realizada pelo fabricante da dieta. Os compostos foram enviados para o fabricante com as especificações detalhadas para a incorporação Os cálculos foram realizados considerando a massa corporal média e o consumo médio de dieta de camundongos na 19 a semana de vida, alimentados com o mesmo tipo de dieta (considerando estudos anteriores realizados no FARMOL).

Considerando-se uma massa corporal de 37 gramas, para se atingir o consumo diário de $1 \mu \mathrm{g}$ por quilo (massa do animal), cada animal deveria ingerir 0,037 $\mathrm{gg}$ do 
composto diariamente. Dado que cada animal consome em média 2,5 $\mathrm{g}$ de dieta por dia, conclui-se que $1 \mathrm{~kg}$ de dieta deveria conter $14,8 \mu \mathrm{g}$ de TBTC. Para o cálculo dos outros compostos (TBTC $5 \mu \mathrm{g} / \mathrm{Kg}$, rosiglitazona $10 \mathrm{mg} / \mathrm{Kg}, \mathrm{GQ}-1640 \mathrm{mg} / \mathrm{Kg}$ ) baseouse na memória de cálculo utilizada para a concentração de TBTC $1 \mu \mathrm{g} / \mathrm{Kg}$, substituindo cada concentração para definir a massa diária ingerida de cada composto. Desse modo, obteve-se, respectivamente, para cada quilo de dieta, $74 \mu \mathrm{g}$ de TBTC $(5 \mu \mathrm{g} / \mathrm{Kg})$, $148 \mathrm{mg}$ de rosiglitazona $(10 \mathrm{mg} / \mathrm{Kg})$ e $592 \mathrm{mg}$ de GQ-16(40mg/Kg)

\subsubsection{Dieta normolipídica}

Nesse modelo experimental, 16 animais foram divididos aleatoriamente em grupos de 4 animais e alojados em gaiolas individuais. Eles foram alimentados com dieta normolipídica desde a chegada ao biotério, com 4 semanas de vida até a eutanásia, que ocorreu na $21^{\underline{a}}$ semana de vida. O tratamento consistiu na administração do composto TBTC diluído na água de beber, da 9a semana de vida até a eutanásia.

A opção pela administração do TBTC na água foi para mimetizar a exposição humana, uma vez que vários estudos mostraram a presença desse composto na água de rios e lagos (124-126).

Os grupos de estudo e os respectivos tratamentos foram os seguintes:

Grupo 1 - Controle: ofertada somente água filtrada.

Grupo 2 - TBTC $1 \mu \mathrm{g} / \mathrm{Kg}$ de massa corpórea por dia.

Grupo 3 - TBTC $5 \mu \mathrm{g} / \mathrm{Kg}$ de massa corpórea por dia.

Grupo 4 -TBTC $25 \mu \mathrm{g} / \mathrm{Kg}$ de massa corpórea por dia. 


\subsubsection{Dieta hiperlipídica}

Nesse modelo experimental, investigou-se o potencial efeito do TBTC em camundongos com hiperglicemia induzida por dieta hiperlipídica, comparando-o com outros agonistas de PPAR $\gamma$, rosiglitazona e GQ-16. Resultados ainda não publicados do nosso grupo de pesquisa apontaram que em células, semelhante à rosiglitazona, - TBTC possui efeito repressor de genes relacionados à inflamação, obesidade e resistência à insulina, de modo que a investigação do potencial efeito do TBTC nesse contexto mostrou-se muito interessante.

Além disso, embora a administração do TBTC na água, realizada na primeira etapa do estudo, não tenha alterado a ingestão hídrica dos animais, comparados aos que receberam somente água, nessa segunda etapa, o TBTC assim como os demais compostos avaliados, foram incorporados à dieta.

A dieta também é uma possível fonte de contaminação dos seres humanos pelo TBTC (127). Além disso, a incorporação do TBTC à dieta apresentou como vantagem técnica a redução da manipulação do composto pelos pesquisadores, além da significativa diminuição do volume de TBTC gerado como resíduo, uma vez que o volume preparado semanalmente era aproximadamente 66 vezes maior que o consumido pelos amimais.

Os grupos de estudo e os respectivos tratamentos foram os seguintes:

Grupo 1 - Controle: ofertada apenas a dieta hiperlipídica.

Grupo 2 - Dieta hiperlipídica acrescida de rosiglitazona $10 \mathrm{mg} / \mathrm{Kg}$ de massa corpórea por dia.

Grupo 3 - Dieta hiperlipídica acrescida de GQ-16 40 mg/Kg de massa corpórea por dia.

Grupo 4 - Dieta hiperlipídica acrescida de TBTC $1 \mu \mathrm{g} / \mathrm{Kg}$ de massa corpórea por dia.

Grupo 5 - Dieta hiperlipídica acrescida de TBTC $5 \mu \mathrm{g} / \mathrm{Kg}$ de massa corpórea por dia. 


\subsubsection{Avaliação da massa corporal, consumo de dieta, ingestão hídrica e glicemia de jejum}

Durante todo o período, foram avaliados a massa corporal, o consumo de dieta e ingestão hídrica de todos animais, três vezes por semana. A glicemia capilar, nos camundongos alimentados com dieta normolipídica, foi avaliada somente ao final do tratamento, na $21^{\text {a }}$ semana de vida. Já nos animais alimentados com dieta hiperlipídica a glicemia foi aferida na $16^{\mathrm{a}}$ semana de vida, antes do início do tratamento, quando foi constatada hiperglicemia induzida pela dieta, na $17^{\mathrm{a}}, 18^{\mathrm{a}}, 20^{\mathrm{a}}$ e $22^{\mathrm{a}}$ semanas de vida.

No momento da aferição da glicemia os animais estavam em jejum (água e dieta) de 12 a 14 horas. A coleta do sangue foi realizada por meio de punção de veia da cauda e para a mensuração foi utilizado o aparelho Accu-Chek Performa (Roche).

\subsubsection{Eutanásia e coleta de sangue e tecidos}

Ao final do tratamento, os animais foram eutanasiados seguindo as diretrizes sugeridas pela Associação Americana de Medicina Veterinária (AVMA, 2013) (128).

No momento da eutanásia os animais estavam em jejum de 12 a 14 horas, privados apenas de dieta. A inconsciência foi induzida por anestesia pelo isoflurano e imediatamente após a percepção da perda dos sentidos, os animais foram decapitados com guilhotina. As amostras de sangue foram coletadas do tronco, centrifugadas a $4000 \mathrm{rpm}$ e $4^{\circ} \mathrm{C}$ durante 15 minutos e armazenadas em freezer a $80^{\circ} \mathrm{C}$ para posterior determinação do perfil lipídico. Os animais foram colocados sobre o gelo e dissecados para inspeção e coleta dos tecidos.

Foram coletados, tanto dos animais alimentados com dieta normolipípida quanto dos que receberam dieta hiperlipídica, os tecidos adiposos branco subcutâneo inguinal, branco visceral epididimal e o tecido adiposo marrom interescapular, o 
coração, fígado, rins e testículos. O tecido adiposo branco retroperitoneal também foi coletado dos animais alimentados com dieta hiperlipídica.

Todos os tecidos e órgãos foram pesados individualmente, com exceção do fígado dos animais alimentados com dieta normolipídica. Fragmentos dos tecidos adiposos e do fígado foram fixados em paraformaldeído $4 \%$ para o preparo posterior de lâminas histológicas e o restante dos tecidos e os demais órgãos foram armazenados em nitrogênio líquido e posteriormente armazenados em freezer a $80^{\circ} \mathrm{C}$.

\subsubsection{Processamento dos tecidos para análise histológica}

\subsubsection{Fixação de tecidos}

Após a coleta, os tecidos foram imediatamente armazenados em tubos contendo solução fixadora (paraformaldeído $4 \%$ v/v em PBS, recém-preparada). Os fragmentos de tecido adiposo branco visceral epididimal, tecido adiposo branco subcutâneo inguinal e tecido adiposo marrom interscapular foram mantidos nessa solução fixadora até o processamento. Já os fragmentos de fígado foram mantidos no paraformaldeído $4 \%$ por 24 horas e então transferidos para outra solução fixadora, solução de Bouin ( $75 \mathrm{~mL}$ de ácido pícrico, $25 \mathrm{~mL}$ de formol, $5 \mathrm{~mL}$ de ácido acético) por 4 horas, e a seguir, foram lavados em solução de álcool etílico $50 \%(\mathrm{v} / \mathrm{v})$ até a retirada do excesso do Bouin e depois conservados em álcool etílico $70 \%(\mathrm{v} / \mathrm{v})$ até o seu processamento.

4.2.6.2 Desidratação, diafanização e inclusão em parafina

O processo de inclusão do tecido na parafina foi realizado manualmente. Os fragmentos dos tecidos foram transferidos para cassetes tradicionais e submetidos à 
desidratação em álcool em concentrações crescentes progressivas: 1 hora em cada concentração (álcool 30, 50, 70, 80 e 90\% -v/v e finalmente 2 vezes em álcool absoluto). Após a desidratação, os tecidos passaram pela diafanização e inclusão na parafina por imersão (banho) nas seguintes soluções e respectivos tempos:

$\checkmark 1$ banho na solução de álcool absoluto e xilol $50 \%$ (v/v) por 1 hora.

$\checkmark 2$ banhos em xilol absoluto por 1 hora cada.

$\checkmark 1$ banho em xilol e parafina $50 \%(\mathrm{v} / \mathrm{v})$ fundida na estufa à $60^{\circ} \mathrm{C}$ por 30 minutos

$\checkmark 3$ banhos em parafina à $60^{\circ} \mathrm{C}$ por 1 hora cada.

Após os 3 banhos de parafina, os cortes de tecidos foram fixados na parafina em posição vertical e no fundo da forma, com o auxílio de uma pinça pré-aquecida. $O$ material parafinizado foi mantido em temperatura ambiente até a realização de cortes de tecido no micrótomo (Rotary microtome, modelo RM2125, Leica Biosystems, Alemanha).

\subsubsection{Corte no micrótomo}

Antes da microtomia, para evitar enrugamento do tecido durante o corte, os tecidos incluídos em blocos de parafina permaneceram 30 minutos a $-20^{\circ} \mathrm{C}$. Os blocos com os fragmentos de fígado e tecido adiposo foram cortados no micrótomo com espessura de $5 \mu \mathrm{m}$ e $7 \mu \mathrm{m}$, respectivamente. Os fragmentos obtidos foram transferidos para banho-maria $\left(40^{\circ} \mathrm{C}\right)$, distendidos com o auxílio de uma pinça e aderidos em lâminas. As lâminas foram transferidas para estufa a $60^{\circ} \mathrm{C}$ por aproximadamente 2 horas e depois armazenadas à temperatura ambiente. 
4.2.6.4 Coloração com hematoxilina-eosina

Antes de iniciar a etapa de coloração das lâminas com hematoxilina e eosina, as mesmas foram colocadas na estufa a $60 \stackrel{\circ}{\mathrm{C}}$ para a desparafinização por 30 minutos e em seguida, foram imersas nos seguintes banhos de reidratação:

$\checkmark$ xilol (3 banhos por 2 minutos)

$\checkmark$ álcool etílico absoluto (3 banhos por 2 minutos)

$\checkmark$ álcool etílico 95\% (1 banho por 2 minutos)

$\checkmark$ álcool etílico $80 \%$ (1 banho por 2 minutos)

$\checkmark$ álcool etílico $70 \%$ (1 banho por 2 minutos)

$\checkmark$ álcool etílico $50 \%$ (1 banho por 2 minutos)

$\checkmark$ água corrente por 3 minutos

$\checkmark$ água destilada (1 banho)

Em seguida as laminas foram imersas em solução de hematoxilina de Harris (5 mg hematoxilina, $50 \mathrm{~mL}$ de álcool absoluto, $100 \mathrm{mg}$ de alúmen de potássio, 2,5 g de óxido vermelho de mercúrio, $1000 \mathrm{~mL}$ de água destilada) por 2 minutos as amostras de fígado e 5 minutos as de tecido adiposo.

Posteriormente as lâminas foram lavadas em água corrente para retirada do excesso de hematoxilina, mergulhadas em água destilada e imersas rapidamente em álcool ácido (ácido clorídrico 1\% em álcool 70\%) e novamente lavadas em água destilada, seguindo para a coloração por eosina. Para imersão em eosina, as lâminas foram inicialmente imersas em solução Scott (Leica Biosystems, Alemanha), lavadas em água corrente e em água destilada. Após retirada o excesso de água destilada, as lâminas foram imersas em eosina alcoólica 1\% por 1 minuto. Em seguida, as lâminas foram imersas em álcool etílico 95\%-v/v (3 banhos sendo 1 minuto cada) e a seguir em álcool etílico absoluto ( 6 banhos de 1 minuto cada). Para finalização do processo de coloração, as lâminas foram imersas em xilol (3 banhos de 1 minuto cada).

Após secagem, a montagem das lâminas foi realizada utilizando-se o meio sintético Entellan e lamínula. (Entellan new, Sigma-Aldrich, St. Louis, USA). As imagens dos cortes de tecidos foram capturadas por um scaner (ScanScope® CS 
System) com aumento de 10 vezes e as imagens foram processadas no programa Aperio Image Scope v.12.2.2.5015.

\subsection{ANÁLISE ESTATÍSTICA}

Os dados foram analisados no programa estatístico Graph Pad Prism 5.0. Todos os resultados foram expressos como média \pm erro padrão da média (EPM). A análise de variância de um fator (one way ANOVA) ou a análise de variância de dois fatores (two-way ANOVA) seguida do pós-teste de Bonferroni foram utilizadas para comparar as médias entre múltiplos grupos em relação ao tratamento ao longo do tempo. O nível de significância adotado foi $p<0,05$. 


\section{RESULTADOS}

Neste trabalho foram utilizados dois modelos experimentais nos quais camundongos C57BI/6 foram alimentados com dieta normolipídica ou hiperlípidica e tratados ou não com TBTC.

\subsection{AVALIAÇÃO DA MASSA CORPORAL DOS ANIMAIS ALIMENTADOS COM DIETA NORMOLIPÍDICA E TRATADOS COM TBTC}

A avaliação do ganho de massa corporal dos camundongos alimentados com dieta normolipídica e tratados durante 13 semanas, da $9^{a}$ à $21^{\text {a }}$ semana de vida, com TBTC diluído na água mostrou que essa variável não foi diferente dos animais que receberam água sem TBTC (controle) (Figura 6A e 6B). Os resultados foram semelhantes para os animais tratados com TBTC nas concentrações de 1, 5 ou 25 $\mu \mathrm{g} / \mathrm{Kg} / \mathrm{dia}$.

Analisando somente o período de tratamento com o TBTC, não foi observada diferença estatisticamente significante no ganho de massa corporal (diferença entre a massa corporal da $21^{\text {a }}$ semana e da $9^{\text {a }}$ semana de vida) entre os grupos experimentais, embora os animais que receberam TBTC na concentração de $5 \mu \mathrm{g} / \mathrm{Kg}$ tenham apresentado uma tendência de maior ganho (Figura 6B). Assim, os animais controle apresentaram um ganho de massa de 7,57 $\pm 1,19 \mathrm{~g}$, enquanto os camundongos tratados com TBTC nas doses de 1,5 ou $25 \mu \mathrm{g} / \mathrm{Kg} / \mathrm{dia}$ apresentaram um incremento corporal de $7,82 \pm 0,87 \mathrm{~g} ; 8,84 \pm 0,29 \mathrm{~g}$ e 7,26 $\pm 0,97 \mathrm{~g}$ respectivamente $(p=0,641)$. 
A

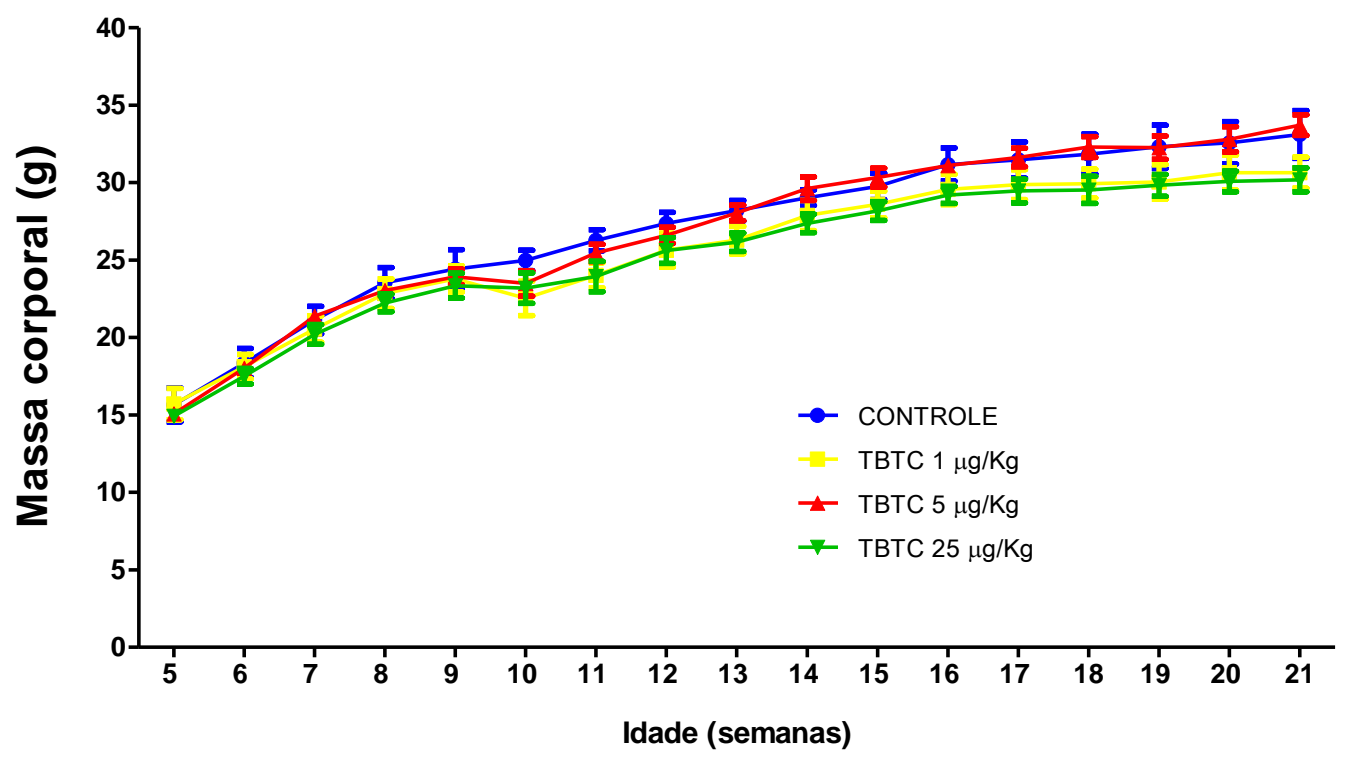

B

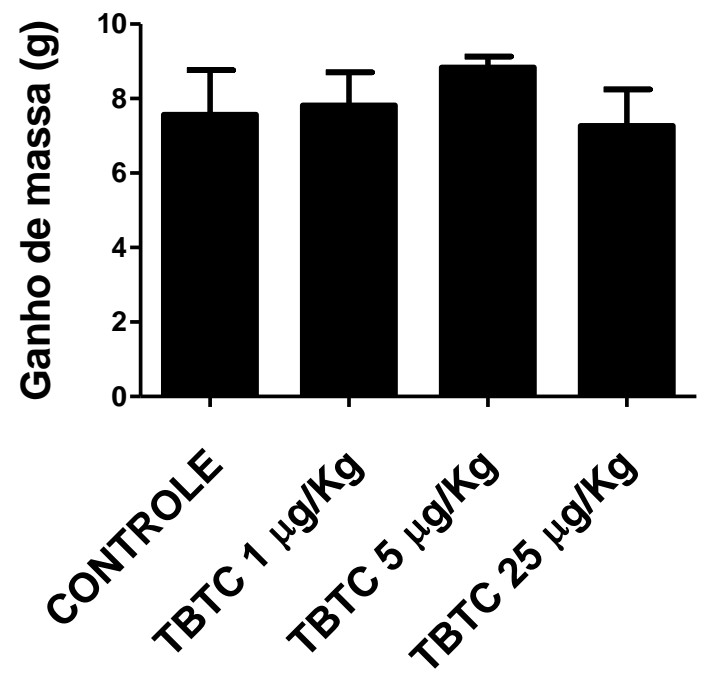

Figura 6. Massa corporal dos camundongos alimentados com dieta normolipídica (A) Massa corporal da $5^{\text {a }}$ a $21^{\text {a }}$ semana de vida. (B) Ganho de massa corporal durante o tratamento ( $9^{\mathrm{a}}$ até a $21^{\mathrm{a}}$ semana de vida). Os camundongos foram alimentados com dieta normolipídica da $5^{\underline{a}}$ à $21^{\underline{a}}$ semana de vida $e$ tratados com água (controle) ou com TBTC $(1,5$ ou $25 \mu \mathrm{g} / \mathrm{Kg})$ na água de beber da $9^{\text {a }}$ até a $21^{\text {a }}$ semana de vida $(n=4)$. Não houve diferença entre os grupos. Dados apresentados como média \pm EPM. (Análise de variância (ANOVA) de dois fatores para figura $6 \mathrm{~A}$ e um fator para figura $6 \mathrm{~B}$ ) Figura $6 \mathrm{~A} p=0,6488 \mathrm{e}$ Figura $6 \mathrm{~B} p=0,6418$ ). 
5.2 AVALIAÇÃO DA INGESTÃO DE DIETA E INGESTÃO HÍDRICA DOS ANIMAIS ALIMENTADOS COM DIETA NORMOLIPÍDICA

Com o objetivo de verificar se o tratamento com o TBTC poderia influenciar a ingestão de água ou de dieta, o consumo dos animais tratados com dieta normolipídica foi mensurado três vezes por semana. Foi observado que não houve diferença estatisticamente significante no consumo de água e dieta entre o grupo controle e os tratados com TBTC diluído na água (Figuras 7A e 7B). Estes resultados mostram que a ingestão do TBTC nas três concentrações (1, 5 ou $25 \mu \mathrm{g} / \mathrm{Kg} / \mathrm{dia}$ ) não alterou significativamente o consumo de dieta e água, quando comparado aos animais que beberam somente água (controle).

A diluição do TBTC na água foi realizada semanalmente. Analisando os dados dispostos individualmente por animal na Tabela 1, depreende-se que a quantidade de água ingerida pelos animais foi em média próxima às concentrações desejadas de TBTC. Na Tabela 1 foram utilizados os dados de massa e consumo diário de cada animal na 16 ${ }^{\text {a }}$ semana de vida para exemplificar a forma de controle do consumo do TBTC nas três concentrações (1, 5 ou $25 \mu \mathrm{g} / \mathrm{Kg} / \mathrm{dia})$, conforme o programado.

Tabela 1- Dados da ingestão hídrica individual diária de cada concentração de TBTC. Médias apresentadas com Erro Padrão da Média (EPM)

\begin{tabular}{|c|c|c|c|c|c|c|}
\hline $\begin{array}{l}\text { Objetivo } \\
\text { do estudo }\end{array}$ & Animal & $\begin{array}{c}\text { Consumo } \\
\text { hídrico } \\
\text { diário } \\
(\mathrm{mL})\end{array}$ & $\begin{array}{c}\text { Massa do animal } \\
\text { (g) }\end{array}$ & $\begin{array}{l}\text { Massa do } \\
\text { animal } \\
(\mathrm{Kg})\end{array}$ & $\begin{array}{c}\text { TBTC } \\
\text { em } 1 \mathrm{~mL} \\
\text { de água }\end{array}$ & $\begin{array}{l}\text { Concentração } \\
(\mu \mathrm{g}) \text { deTBTC } \\
\text { ingerido por } \\
\mathrm{kg} \text { de massa }\end{array}$ \\
\hline \multirow{5}{*}{$\begin{array}{l}\text { TBTC } \\
1 \mu \mathrm{g} / \mathrm{Kg}\end{array}$} & M1G2 & 1,44 & 27,01 & 0,03701 & \multirow{5}{*}{$0,015 \mu \mathrm{g}$} & 0,800 \\
\hline & M2G2 & 2,61 & 31,63 & 0,03163 & & 1,238 \\
\hline & M3G2 & 1,89 & 29,27 & 0,02927 & & 0,969 \\
\hline & M4G2 & 2,06 & 30,38 & 0,03038 & & 1,017 \\
\hline & média & $2,00 \pm 0,24$ & $29,57 \pm 0,98$ & 0,02957 & & $1,014 \pm 0,090$ \\
\hline \multirow{5}{*}{$\begin{array}{c}\text { TBTC } \\
5 \mu \mathrm{g} / \mathrm{Kg}\end{array}$} & M1G3 & 1,67 & 31,09 & 0,03109 & \multirow{5}{*}{$0,075 \mu \mathrm{g}$} & 4,029 \\
\hline & M2G3 & 1,33 & 32,35 & 0,03235 & & 3,083 \\
\hline & M3G3 & 2,22 & 30,34 & 0,03034 & & 5,488 \\
\hline & M4G3 & 1,72 & 30,69 & 0,03069 & & 4,203 \\
\hline & média & $1,74 \pm 0,18$ & $31,11 \pm 0,44$ & 0,03112 & & $4,182 \pm 0,495$ \\
\hline \multirow{5}{*}{$\begin{array}{c}\text { TBTC } \\
25 \mu \mathrm{g} / \mathrm{Kg}\end{array}$} & M1G4 & 1,83 & 29,66 & 0,02966 & \multirow{5}{*}{$0,375 \mu \mathrm{g}$} & 23,137 \\
\hline & M2G4 & 2,61 & 28,93 & 0,02893 & & 33,832 \\
\hline & M3G4 & 2,06 & 27,82 & 0,02782 & & 27,768 \\
\hline & M4G4 & 2.06 & 30,43 & 0.03043 & & 25,386 \\
\hline & média & $2,14 \pm 0,16$ & $29,21 \pm 0,55$ & 0,02921 & & $27,473 \pm 2,303$ \\
\hline
\end{tabular}



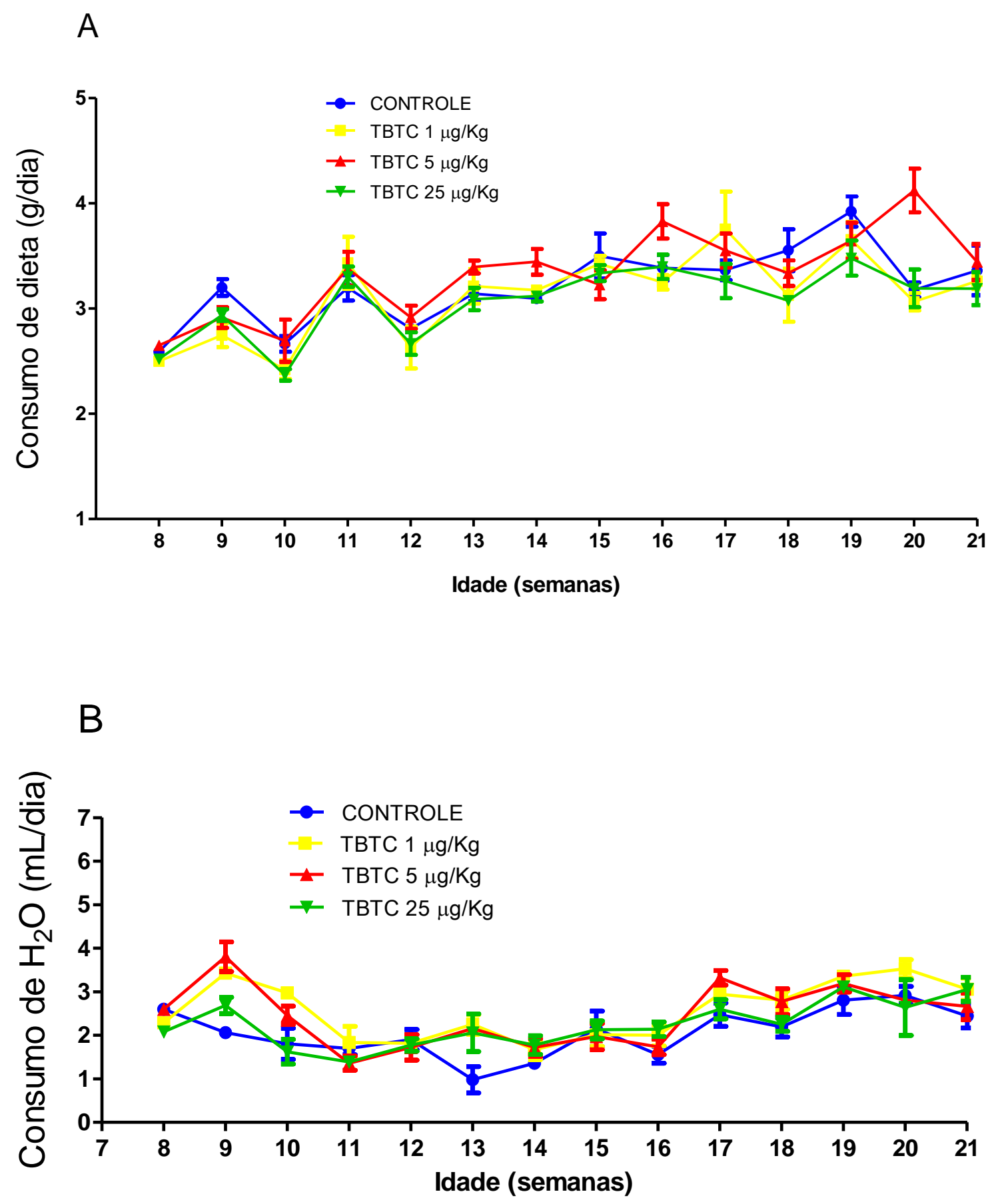

Figura 7. Consumo de dieta e água dos camundongos alimentados com dieta normolipídica. (A) Consumo de dieta (B) Consumo de água. Os camundongos foram alimentados com dieta normolipídica da $5^{\mathrm{a}}$ até a $21^{\mathrm{a}}$ semana de vida e tratados somente com água (controle) ou com TBTC $(1,5$ ou $25 \mu \mathrm{g} / \mathrm{Kg})$ na água de beber da $9^{\underline{a}}$ até a $21^{\underline{a}}$ semana de vida $(\mathrm{n}=4)$. Não houve diferença entre os grupos. Dados apresentados como média \pm EPM. (Análise de variância (ANOVA) de dois fatores. Figura 7A $p=0,3042$ e Figura 7B $p=0,6785$. 
5.3 AVALIAÇÃO DA GLICEMIA EM JEJUM DOS ANIMAIS ALIMENTADOS COM DIETA NORMOLIPÍDICA

A glicemia capilar dos animais alimentados com dieta normolipídica foi aferida somente no final do tratamento, na 19ª semana de vida. Como é possível observar na Figura 8, não houve diferença estatisticamente significante entre os grupos tratados com o TBTC e o grupo controle. Assim, os animais controle apresentaram na $19^{a}$ semana uma glicemia no valor de 94,25 $\pm 5,34 \mathrm{mg} / \mathrm{dL}$ enquanto que os camundongos tratados com TBTC nas doses de 1, 5 ou $25 \mu \mathrm{g} / \mathrm{Kg} / \mathrm{dia}$ apresentaram glicemia capilar de $110,00 \pm 5,34 \mathrm{mg} / \mathrm{dL} ; 94,50 \pm 8,70 \mathrm{mg} / \mathrm{dL}$ e $88,00 \pm 4,06 \mathrm{mg} / \mathrm{dL}$, respectivamente $(p=0,3054)$.

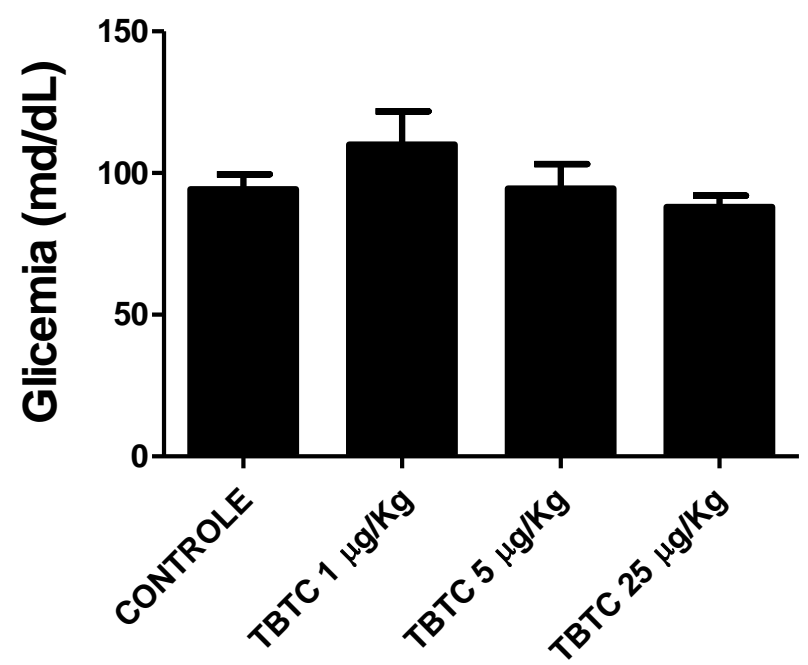

Figura 8. Glicemia dos camundongos alimentados com dieta normolipídica. Glicemia em jejum aferida na $19^{a}$ semana de vida dos camundongos. Não houve diferença entre os grupos. Dados apresentados como média \pm EPM. (Análise de variância (ANOVA) de um fator) $(p=0,3054)$ 


\subsection{AVALIAÇÃO DA MASSA DOS TECIDOS ADIPOSOS E ÓRGÃOS DOS ANIMAIS ALIMENTADOS COM A DIETA NORMOLIPÍDICA}

Após a eutanásia, os animais foram dissecados e os tecidos adiposos brancos subcutâneo inguinal, visceral epididimal, e tecido adiposo marrom interescapular foram coletados e pesados. Além dos tecidos adiposos, foram coletados coração, rins e testículos. Foi observado que não houve diferença estatisticamente significante entre os grupos mostrando que o tratamento não interferiu na massa do Tecido Adiposo Branco (TAB) (Figura 9). Os órgãos foram pesados e também não apresentaram diferença estatisticamente significante entre os grupos controle e tratados com TBTC nas concentrações de 1,5 ou $25 \mu \mathrm{g} / \mathrm{Kg} / \mathrm{dia}$. Os valores da razão da massa do órgão (tecido em $\mathrm{mg}$ ) dividido pela massa corporal do animal (g), bem como a probabilidade de significância $(p)$ estão representados na tabela 2.

Tabela 2 - Valor de $p$ e massa dos tecidos e órgãos dos camundongos alimentados com dieta normolipídica. Médias apresentadas com Erro Padrão da Média (EPM).

\begin{tabular}{ccccccc} 
& $\begin{array}{c}\text { TAB } \\
\text { inguinal }\end{array}$ & $\begin{array}{c}\text { TAB } \\
\text { Epididimal }\end{array}$ & $\begin{array}{c}\text { TAM Inter } \\
\text { escapular }\end{array}$ & Coração & Rins & Testículos \\
\hline $\begin{array}{c}\text { Valor de } \\
p\end{array}$ & $p=0,5045$ & $p=0,3021$ & $p=0,9886$ & $p=0,3624$ & $p=0,0667$ & $p=0,2800$ \\
\hline & $\begin{array}{c}\mathrm{mg} / \mathrm{g} \text { de } \\
\mathrm{massa}\end{array}$ & $\begin{array}{c}\mathrm{mg} / \mathrm{g} \text { de } \\
\mathrm{massa}\end{array}$ & $\begin{array}{c}\mathrm{mg} / \mathrm{g} \text { de } \\
\mathrm{massa}\end{array}$ & $\begin{array}{c}\mathrm{mg} / \mathrm{g} \mathrm{de} \\
\mathrm{massa}\end{array}$ & $\begin{array}{c}\mathrm{mg} / \mathrm{g} \mathrm{de} \\
\mathrm{massa}\end{array}$ & $\begin{array}{c}\mathrm{mg} / \mathrm{g} \mathrm{de} \\
\mathrm{massa}\end{array}$ \\
\hline CONTROLE & $13,35 \pm 2,77$ & $36,28 \pm 1,66$ & $4,63 \pm 0,84$ & $4,35 \pm 0,13$ & $9,59 \pm 0,35$ & $5,68 \pm 0,31$ \\
\hline TBTC $\mathbf{1} \mathbf{\mu g} / \mathbf{K g}$ & $13,02 \pm 1,92$ & $32,38 \pm 2,13$ & $4,40 \pm 0,47$ & $4,33 \pm 0,19$ & $11,02 \pm 0,33$ & $6,20 \pm 0,41$ \\
\hline TBTC $\mathbf{~} \mathbf{\mu g} / \mathbf{K g}$ & $17,11 \pm 0,95$ & $36,69 \pm 2,79$ & $4,52 \pm 0,26$ & $4,83 \pm 0,35$ & $9,80 \pm 0,56$ & $5,48 \pm 0,21$ \\
\hline TBTC $\mathbf{2 5} \boldsymbol{\mu g} / \mathbf{K g}$ & $14,47 \pm 2,08$ & $32,24 \pm 1,46$ & $4,64 \pm 0,44$ & $4,26 \pm 0,22$ & $10,77 \pm 0,31$ & $6,33 \pm 0,39$
\end{tabular}



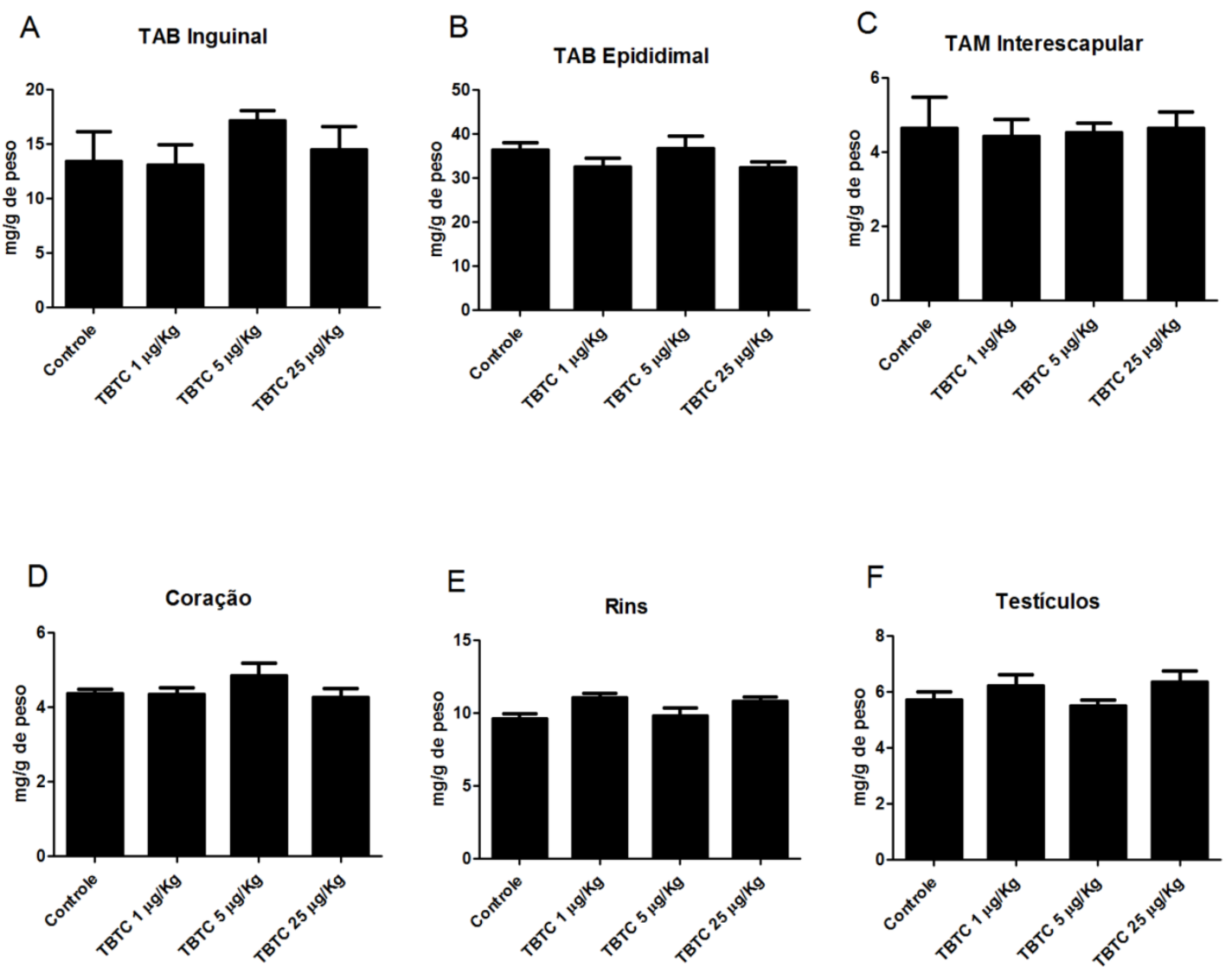

Figura 9. Massa dos tecidos e órgãos dos camundongos alimentados com dieta normolipídica. (A) Tecido Adiposo Branco (TAB) Inguinal, (B) Tecido Adiposo Branco (TAB) Epididimal, (C) Tecido Adiposo Marrom (TAM) interescapular, (D) Coração, (E) Rins, (F) Testículos. Grupos de $n=4$ animais. Não houve diferença entre os grupos. Dados apresentados como média \pm EPM. Análise de variância (ANOVA) de um fator Figura 9A $p=0,5045$; Figura 9B $p=0,3021$; Figura 9C $p=0,9886$; Figura 9D $p$ $=0,3624$; Figura 9E $p=0,0667$ e Figura $9 F$

Considerando que a administração de TBTC não modificou nenhum dos parâmetros metabólicos analisados (massa corporal, ingestão de água e dieta, glicemia e adipogênese) nos camundongos submetidos à dieta normolipídica, decidiuse investigar se o efeito adipogênico do TBTC poderia surgir nos animais submetidos à dieta hiperlipídica. Além disso, como nesses animais já está bem definido que rosiglitazona melhora a glicemia, comparou-se o efeito do TBTC com a rosiglitazona e o GQ-16, um agonista parcial que também melhora o controle glicêmico desses animais. Como ter-se-ia que conduzir 5 grupos com 5 animais em cada um, totalizando 25 animais, resolveu-se administrar todas os compostos incorporados à dieta. Para isso foi solicitado ao fabricante (PRAGSOLUÇÕES) a mistura de cada um dos compostos à sua respectiva dieta. 
5.5 AVALIAÇÃO DA MASSA CORPORAL DOS ANIMAIS TRATADOS COM TBTC E ALIMENTADOS COM DIETA HIPERLIPÍDICA

Todos os animais apresentaram um aumento gradativo da massa corporal ao longo do tempo. Porém, a avaliação do ganho de massa corporal dos camundongos alimentados com dieta hiperlipídica e tratados durante 6 semanas, da $17^{\mathrm{a}}$ à $22^{\mathrm{a}}$ semana de vida, com os compostos rosiglitazona $10 \mathrm{mg} / \mathrm{Kg}$, GQ-16 $40 \mathrm{mg} / \mathrm{Kg}$ ou TBTC em duas concentrações (1 e $5 \mu \mathrm{g} / \mathrm{Kg}$ ) não mostrou diferença entre os grupos (Figura 10A).

Os dados são confirmados quando realizamos a análise do ganho de massa corporal durante o período de tratamento, mostrando que não houve diferença estatisticamente significante entre os grupos experimentais. No entanto, os animais tratados com GQ-16 $40 \mathrm{mg} / \mathrm{Kg}$ apresentaram um menor ganho quando comparado aos demais grupos. Enquanto os animais do grupo tratado com rosiglitazona aumentaram sua massa em $3,67 \pm 0,51 \mathrm{~g}$, TBTC $1 \mu \mathrm{g} / \mathrm{Kg}$ em 3,23 $\pm 0,60 \mathrm{~g}$ e o TBTC 5

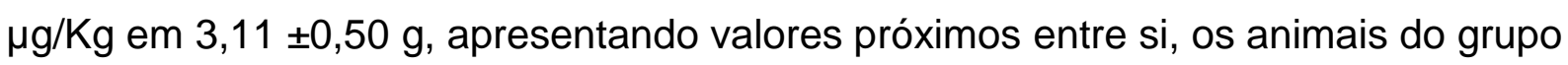
tratado com GQ-16 ganhou somente 2,22g $\pm 0,51$ e os animais do grupo controle 4,06g $\pm 0,69$. Mesmo não sendo estatisticamente significante, em comparação ao controle, o grupo tratado com GQ-16 apresentou um ganho de massa corporal aproximadamente $45 \%$ menor. Já na comparação do grupo tratado com o GQ-16 com os demais grupos, este apresentou um ganho de massa 30\% menor (Figura 10B). 


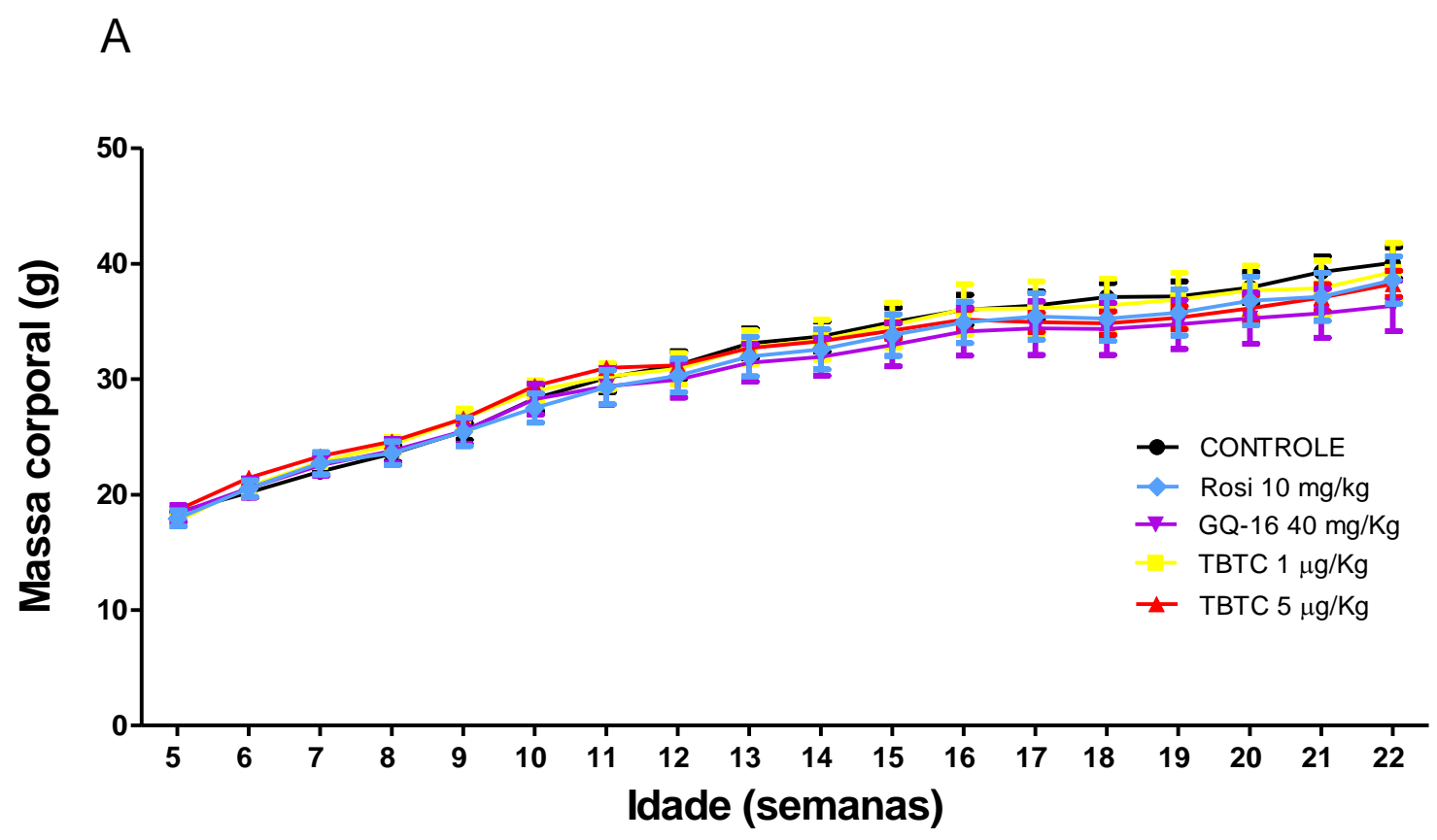

B

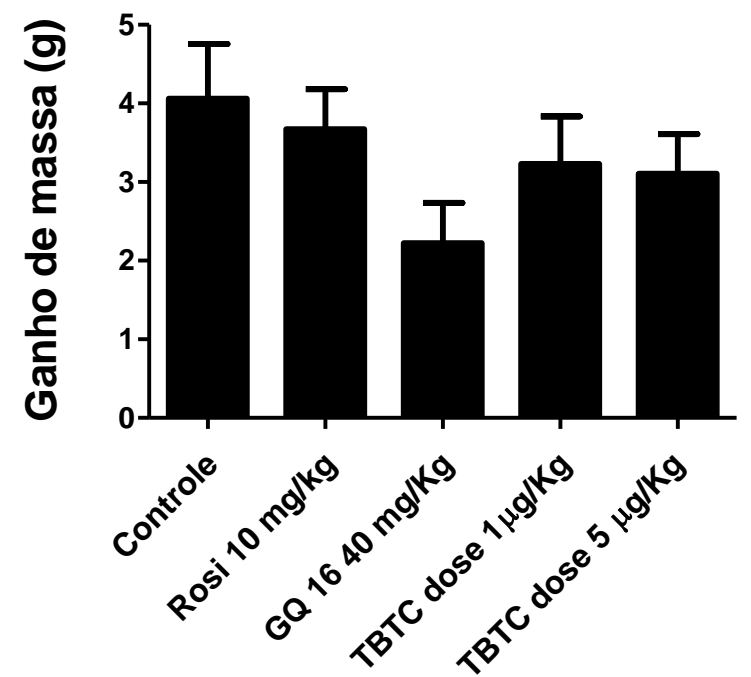

Figura 10. Massa corporal dos camundongos alimentados com dieta hiperlipídica. (A) Massa corporal da $5^{\text {a }}$ à $22^{\underline{a}}$ semana de vida. (B) Ganho de massa corporal durante o tratamento da $17^{\text {a }}$ à $22^{\underline{a}}$ semana de vida. Camundongos alimentados com dieta hiperlipídica da $5^{\underline{a}}$ à $22^{\underline{a}}$ semana de vida e tratados com rosiglitazona, GQ-16 ou TBTC (1 ou $5 \mu \mathrm{g} / \mathrm{Kg})$, incorporados à dieta $(n=5)$. Não houve diferença entre os grupos. Dados apresentados como média \pm EPM. (Análise de variância (ANOVA) de dois fatores para a figura 10A e um fator para a Figura 10B). Valor de $p$ Figura 10A $p=0,9579$ e Figura 10B $p=0,2469)$. 
5.6 AVALIAÇÃO DA INGESTÃO DE DIETA E INGESTÃO HÍDRICA DOS ANIMAIS ALIMENTADOS COM A DIETA HIPERLIPÍDICA

Os consumos de dieta e de água dos animais tratados com dieta hiperlipídica foram mensurados três vezes por semana. Não foram observadas diferenças estatisticamente significantes nos consumos de água e dieta entre os diferentes grupos de estudo (Figuras 11A e 11B). Estes resultados mostram que a ingestão da rosiglitazona $10 \mathrm{mg} / \mathrm{Kg}, \mathrm{GQ}-1640 \mathrm{mg} / \mathrm{Kg}$ ou TBTC em duas concentrações (1 ou 5 $\mu \mathrm{g} / \mathrm{Kg}$ ) não alteraram o consumo de água e dieta quando comparado entre si e aos animais do grupo controle. 
A

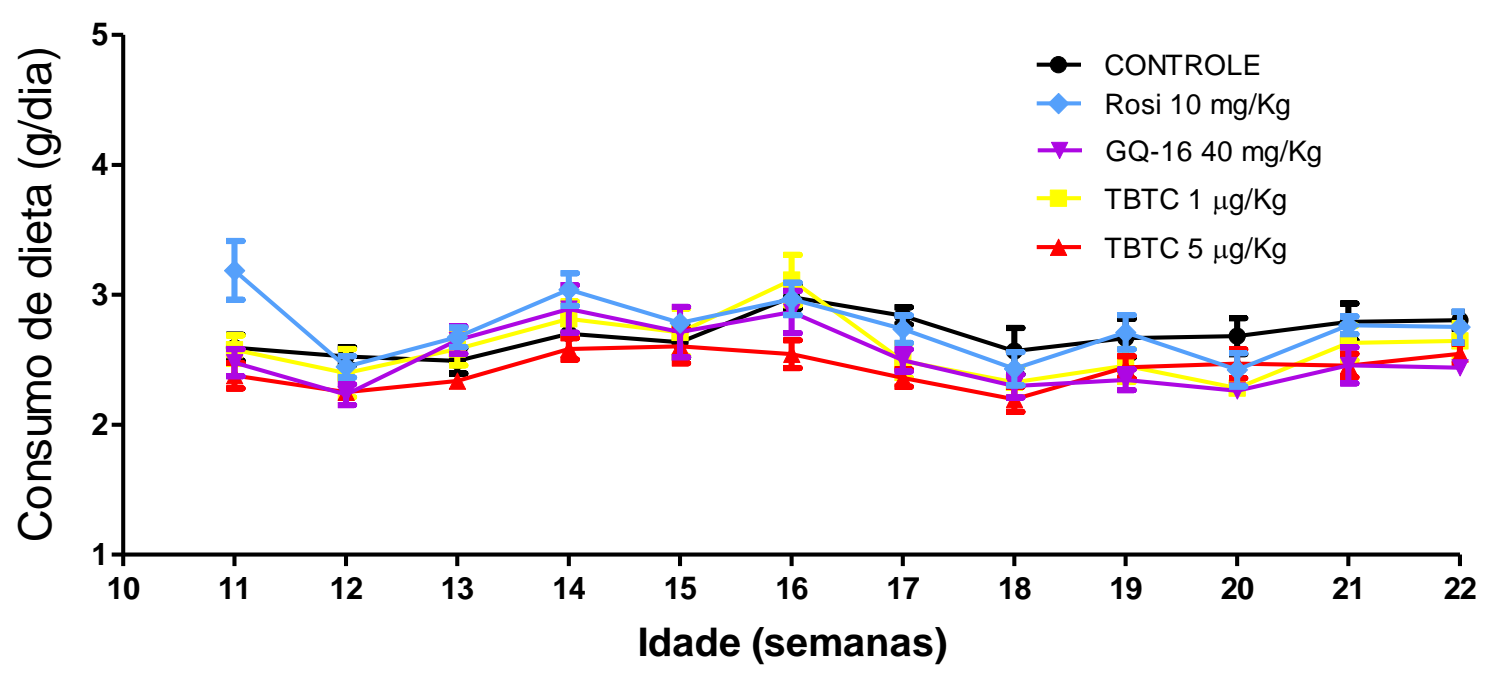

B

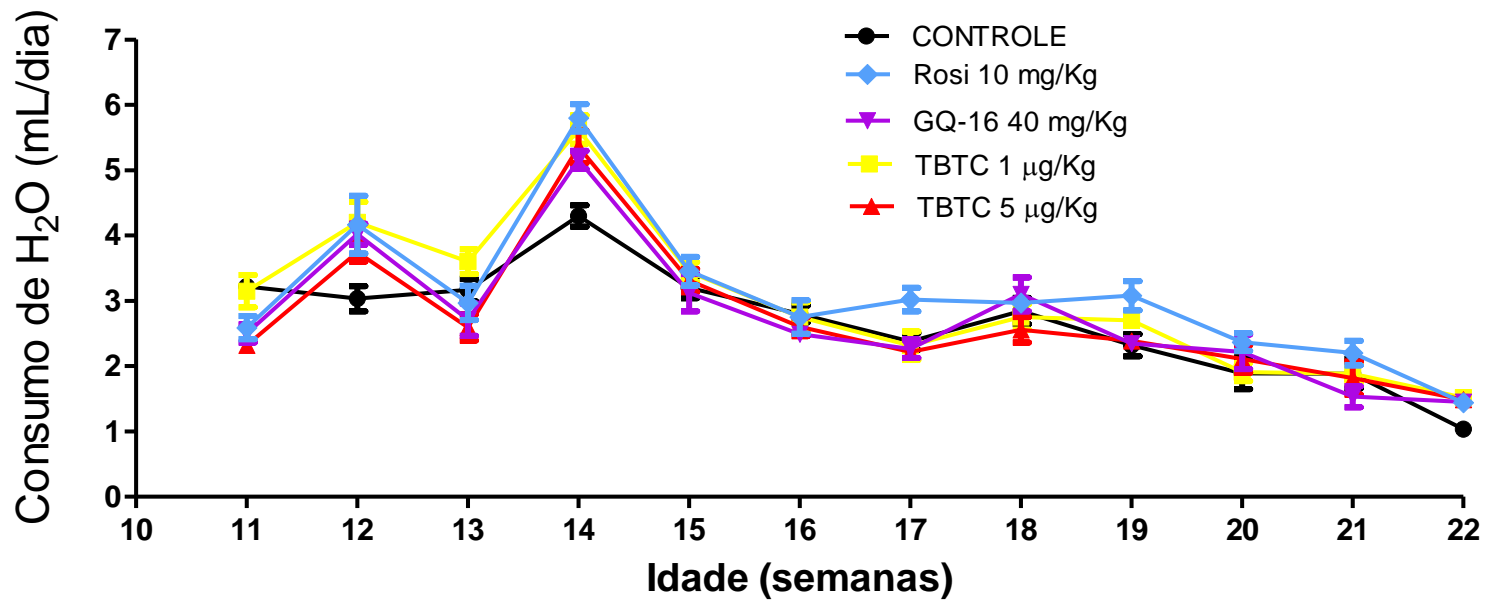

Figura 11. Consumo de dieta e água de camundongos alimentados com dieta hiperlipídica. (A) Consumo de dieta (B) Consumo de água. Os camundongos foram alimentados com dieta hiperlipídica da $5^{\text {a }}$ até a $22^{\text {a }}$ semana de vida e tratados com rosiglitazona, GQ-16 ou TBTC (1 ou 5 $\mu \mathrm{g} / \mathrm{Kg})$, incorporados à dieta pelo fabricante da $17^{\mathrm{a}}$ a $22^{\mathrm{a}}$ semana de vida $(\mathrm{n}=5)$. Não houve diferença entre os grupos. Dados apresentados como média \pm EPM. Análise de variância (ANOVA) de dois fatores. Valor de $p$ Figura 11A $p=0,3042$ e Figura 11B $p=0,6785$. 
Considerando o gráfico anterior (Figura 11A) o qual mostra que não houve variação quanto a ingestão da dieta, utilizou-se os dados de massa e consumo diário de cada animal na 19a semana de vida para exemplificar que a ingestão média dos animais foi equivalente à dose administrada. Comprovando que os valores obtidos estão de acordo com o programado. Os dados estão dispostos individualmente na Tabela 3.

Tabela 3. Dados da ingestão individual diária de TBTC, GQ-16 e rosiglitazona. Médias apresentadas com Erro Padrão da Média (EPM).

\begin{tabular}{|c|c|c|c|c|c|}
\hline $\begin{array}{l}\text { Objetivo do } \\
\text { estudo }\end{array}$ & Animal & $\begin{array}{c}\text { Consumo } \\
\text { diário de dieta } \\
\text { (g) }\end{array}$ & $\begin{array}{c}\text { Massa do } \\
\text { animal } \\
(\mathrm{g})\end{array}$ & $\begin{array}{l}\text { Composto } \\
\text { em } 1 \mathrm{~kg} \text { dieta }\end{array}$ & $\begin{array}{l}\mu \mathrm{g} \text { TBTC } \\
\text { ingerido }\end{array}$ \\
\hline \multirow{5}{*}{$\begin{array}{l}\text { TBTC } \\
1 \mu \mathrm{g} / \mathrm{Kg}\end{array}$} & M1G2 & 2,43 & 32,45 & \multirow{5}{*}{$14,8 \mu \mathrm{g}$} & 1,11 \\
\hline & M2G2 & 2,86 & 44,27 & & 0,96 \\
\hline & M3G2 & 2,49 & 37,88 & & 0,97 \\
\hline & M4G2 & 2,06 & 31,41 & & 0,97 \\
\hline & M5G2 & 2,44 & 38,47 & & 0,94 \\
\hline Média & & $2,46 \pm 0,13$ & $36,9 \pm 2,32$ & & $0,99 \pm 0,03$ \\
\hline \multirow{5}{*}{$\begin{array}{c}\text { TBTC } \\
5 \mu \mathrm{g} / \mathrm{Kg}\end{array}$} & M1G3 & 2,5 & 34,90 & \multirow{5}{*}{$74 \mu g$} & 5,30 \\
\hline & M2G3 & 2,49 & 34,90 & & 5,28 \\
\hline & M3G3 & 2,65 & 39,18 & & 5,00 \\
\hline & M4G3 & 2,13 & 33,38 & & 4,72 \\
\hline & M5G3 & 2,44 & 34,27 & & 5,27 \\
\hline \multirow[t]{2}{*}{ Média } & & $2,44 \pm 0,08$ & $35,33 \pm 1,00$ & & $5,12 \pm 0,11$ \\
\hline & & & & & $\begin{array}{l}\text { mg GQ-16/Rosi } \\
\text { ingerido }\end{array}$ \\
\hline \multirow{5}{*}{$\begin{array}{c}\text { GQ -16 } \\
40 \mathrm{mg} / \mathrm{kg}\end{array}$} & M1G4 & 2,33 & 34,07 & \multirow{5}{*}{$592 \mathrm{mg}$} & 40,48 \\
\hline & M2G4 & 2,57 & 37,67 & & 40,39 \\
\hline & M3G4 & 2,09 & 26,93 & & 45,94 \\
\hline & M4G4 & 2,45 & 39,07 & & 37,12 \\
\hline & M5G4 & 2,29 & 35,99 & & 37,67 \\
\hline Média & & $2,35 \pm 0,08$ & $34,75 \pm 2,12$ & & $40,32 \pm 1,56$ \\
\hline \multirow{5}{*}{$\begin{array}{c}\text { Rosiglitazona } \\
10 \mathrm{mg} / \mathrm{Kg}\end{array}$} & M1G5 & 2,93 & 36,18 & \multirow{5}{*}{$148 \mathrm{mg}$} & 11,98 \\
\hline & M2G5 & 2,36 & 31,15 & & 11,21 \\
\hline & M3G5 & 2,91 & 36,83 & & 11,69 \\
\hline & M4G5 & 2,42 & 32,27 & & 11,10 \\
\hline & M5G5 & 2,94 & 42,42 & & 10,26 \\
\hline Média & & $2,71 \pm 0,29$ & $35,77 \pm 1,99$ & & $11,25 \pm 0,29$ \\
\hline
\end{tabular}


5.7 AVALIAÇÃO DA GLICEMIA EM JEJUM DOS ANIMAIS ALIMENTADOS COM A DIETA HIPERLIPÍDICA

A glicemia capilar foi aferida na $16^{\underline{a}}$ semana (antes de iniciar o tratamento) e nas $17^{\mathrm{a}}, 18^{\mathrm{a}}, 20^{\mathrm{a}}$ e $22^{\mathrm{a}}$ semanas de vida. Na figura 12 , são mostradas as glicemias na $16^{\underline{a}}, 17^{\text {a }}$ e $22^{\underline{a}}$ semana de vida. Na glicemia aferida na $16^{\underline{a}}$ semana de vida, como era esperado, os animais apresentavam hiperglicemia e não houve diferença estatisticamente significante entre os grupos (Figura 12A). Após uma semana de tratamento observou-se que tanto a rosiglitazona quanto o GQ-16 diminuíram os níveis glicêmicos, embora a redução promovida pelo GQ-16 não tenha sido estatisticamente significante. A rosiglitazona foi capaz de reduzir a glicose em aproximadamente $42 \%$ enquanto que o GQ-16 reduziu aproximadamente $15 \%$ quando comparados à glicemia basal (Figura12B). Em contrapartida, os animais tratados com TBTC $1 \mu \mathrm{g} / \mathrm{Kg}$ e $5 \mu \mathrm{g} / \mathrm{Kg}$ não apresentaram redução significativa da glicemia $(162,00 \pm 14,36 \mathrm{mg} / \mathrm{dL}$ e $137,00 \pm 2,21 \mathrm{mg} / \mathrm{dL}$, respectivamente) quando comparados aos animais do grupo controle $(159,2 \pm 15,84 \mathrm{mg} / \mathrm{dL})$. Um cenário semelhante foi observado ao final do tratamento, na $22^{-}$semana de vida, quando os animais do grupo controle apresentaram uma glicemia capilar no valor de $162 \pm 10,24$ $\mathrm{mg} / \mathrm{dL}$ enquanto os animais tratados com rosiglitazona, GQ-16, TBTC $1 \mu \mathrm{g} / \mathrm{Kg}$ e 5 $\mu \mathrm{g} / \mathrm{Kg}$ apresentaram glicemia de 109,5 $\pm 7,96 \mathrm{mg} / \mathrm{dL} ; 120,5 \pm 3,68 \mathrm{mg} / \mathrm{dL} ; 149,8 \pm 14,31$ $\mathrm{mg} / \mathrm{dL}$ e 149,6 $\pm 12,66 \mathrm{mg} / \mathrm{dL}$, respectivamente ( $p=0,0210$ ) (Figura 12C). 
A

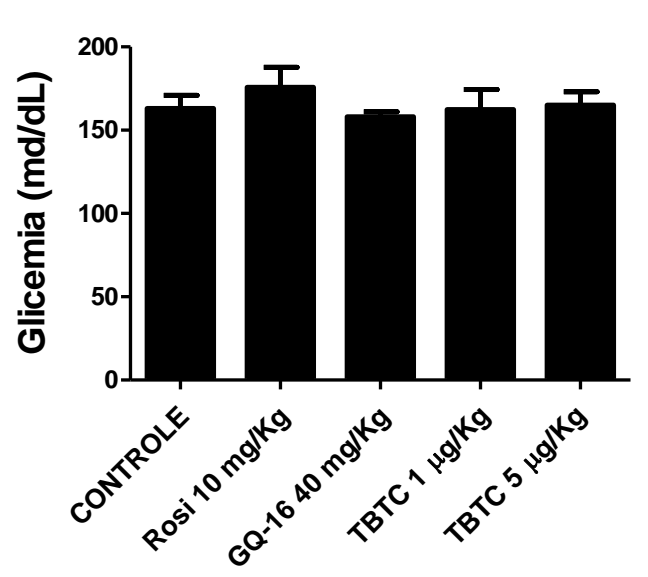

B

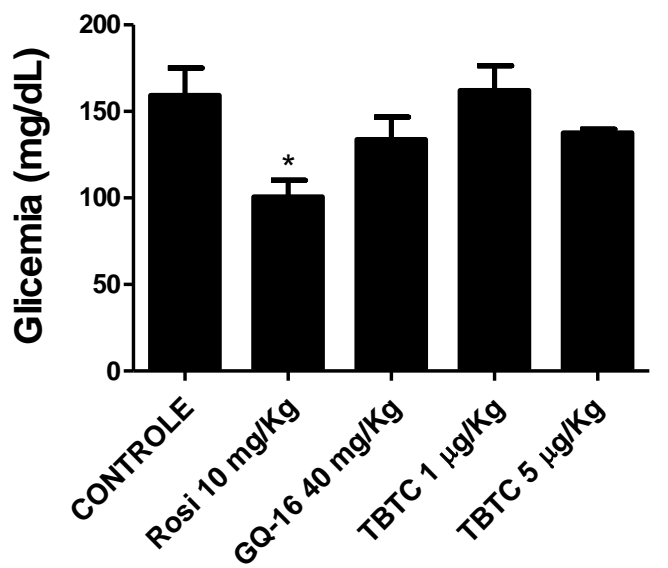

C

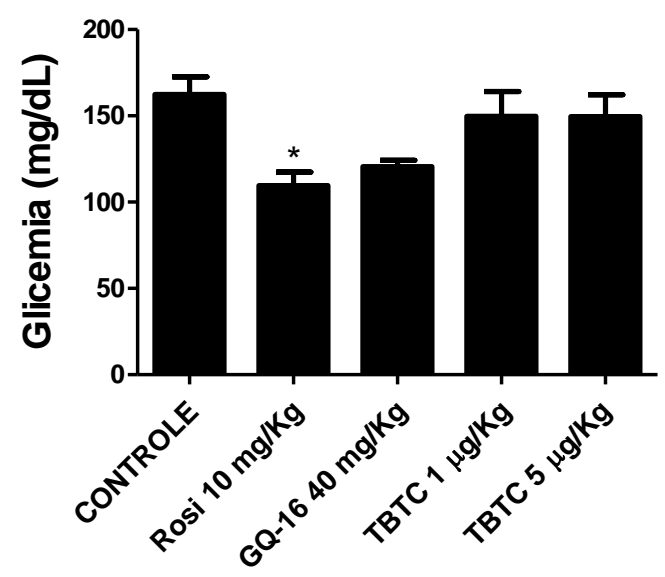

Figura 12. Glicemia dos camundongos alimentados com dieta hiperlipídica. (A) Glicemia em jejum aferida na $16^{\underline{a}}$ semana de vida, antes de iniciar o tratamento. (B) Glicemia em jejum aferida na $17^{\mathrm{a}}$ semana de vida, após uma semana de tratamento. (C) Glicemia em jejum aferida na $22^{a}$ semana de vida, ao término do tratamento. Dados apresentados como média \pm EPM. Análise de variância (ANOVA) de um fator seguida do teste de Bonferroni. ${ }^{*} p<0,05$ vs controle. Figura 12A $p=0.7239$, Figura 12B $p$ $=0,0158$ e Figura 12C $p=0,0210$.

\subsection{AVALIAÇÃO DA MASSA DOS TECIDOS ADIPOSOS E ÓRGÃOS DOS ANIMAIS ALIMENTADOS COM DIETA HIPERLIPÍDICA}

A avaliação da massa dos Tecidos Adiposos Brancos (TAB) não apresentou diferença significativa entre os grupos mostrando que o tratamento não interferiu na massa desses tecidos (Tabela 4). Foram coletados e pesados os tecidos adiposos 
brancos subcutâneo inguinal, retroperitoneal e visceral epididimal. Apesar de as massas do TAB epididimal dos animais tratados com TBTC 1 e $5 \mu \mathrm{g} / \mathrm{Kg}$ apresentarem valores respectivamente, de $51,57 \pm 5,46$ e $54,49 \pm 2,48 \mathrm{mg} / \mathrm{g}$, e serem maiores que a massa do TAB do grupo controle $(48,61 \pm 3,76 \mathrm{mg} / \mathrm{g})$, essa diferença não foi significativa. Também foi coletado e pesado o Tecido Adiposo Marrom interescapular (TAM) que apresentou diferença estatísticamente significante com valor de $p<0,05$ (Tabela 4). Os animais tratados com rosiglitazona apresentaram a massa de TAM aproximadamente $39 \%$ maior que a do controle, enquanto os animais tratados com GQ-16 apresentaram a massa de TAM aproximadamente 48\% menor que o controle. O tratamento com TBTC apesar de não apresentar diferença significativa, mostrou uma tendência de diminuição da massa do tecido marrom interescapular na concentração de $5 \mu \mathrm{g} / \mathrm{Kg}$ (Figura 13). Os valores da razão da massa do órgão (tecido em $\mathrm{mg}$ ) dividido pela massa corporal do animal ( $\mathrm{g}$ ), bem como a probabilidade de significância (p) estão representados na Tabela 4 e os dados dos órgãos na Tabela 5.

Tabela 4. Valor de $p$ e massa dos tecidos dos camundongos alimentados com dieta hiperlipídica. Médias apresentadas com Erro Padrão da Média (EPM).

\begin{tabular}{|c|c|c|c|c|}
\hline & TAB inguinal & TAB Retroperioneal & TAB Epididimal & $\begin{array}{l}\text { TAM Inter } \\
\text { escapular }\end{array}$ \\
\hline \multirow[t]{2}{*}{ Valor de $p$} & $p=0,1075$ & $p=0,8459$ & $p=0,4209$ & $p<0,05$ \\
\hline & $\begin{array}{c}\mathrm{mg} / \mathrm{g} \text { de } \\
\text { massa }\end{array}$ & $\mathrm{mg} / \mathrm{g}$ de massa & $\mathrm{mg} / \mathrm{g}$ de massa & $\mathrm{mg} / \mathrm{g}$ de massa \\
\hline CONTROLE & $38,04 \pm 2,80$ & $23,47 \pm 2,25$ & $48,61 \pm 3,76$ & $6,69 \pm 0,29$ \\
\hline $\begin{array}{c}\text { Rosiglitazona } \\
10 \mathrm{mg} / \mathrm{Kg}\end{array}$ & $24,31 \pm 4,37$ & $19,94 \pm 3,30$ & $42,28 \pm 2,61$ & $10,97 \pm 0,52$ \\
\hline GQ-16 $40 \mathrm{mg} / \mathrm{Kg}$ & $26,91 \pm 4,12$ & $19,86 \pm 3,31$ & $39,21 \pm 5,36$ & $3,43 \pm 0,41$ \\
\hline ТВТС $1 \mu \mathrm{g} / \mathrm{Kg}$ & $27,36 \pm 4,02$ & $23,18 \pm 2,12$ & $51,57 \pm 5,46$ & $5,66 \pm 0,41$ \\
\hline TВTC $5 \mu \mathrm{g} / \mathrm{Kg}$ & $33,32 \pm 1,35$ & $19,86 \pm 3,30$ & $54,49 \pm 2,48$ & $4,68 \pm 0,50$ \\
\hline
\end{tabular}


Tabela 5. Valor de $p$ e massa dos órgãos dos camundongos alimentados com dieta hiperlipídica. Médias apresentadas com Erro Padrão da Média (EPM).

\begin{tabular}{|c|c|c|c|c|}
\hline & Coração & Fígado & Rins & Testículos \\
\hline \multirow[t]{2}{*}{ Valor de $p$} & $p=0,1382$ & $p=0,1719$ & $p=0,6642$ & $p=0,7329$ \\
\hline & $\mathrm{mg} / \mathrm{g}$ de massa & $\mathrm{mg} / \mathrm{g}$ de massa & $\mathrm{mg} / \mathrm{g}$ de massa & $\mathrm{mg} / \mathrm{g}$ de massa \\
\hline CONTROLE & $3,57 \pm 0,15$ & $43,51 \pm 3,17$ & $8,83 \pm 0,34$ & $4,49 \pm 0,28$ \\
\hline $\begin{array}{c}\text { Rosiglitazona } \\
10 \mathrm{mg} / \mathrm{Kg}\end{array}$ & $4,18 \pm 0,18$ & $31,79 \pm 1,34$ & $8,97 \pm 0,44$ & $4,61 \pm 0,29$ \\
\hline $\begin{array}{c}\text { GQ-16 } 40 \\
\mathrm{mg} / \mathrm{Kg}\end{array}$ & $3,70 \pm 0,22$ & $35,06 \pm 2,61$ & $8,39 \pm 0,42$ & $5,44 \pm 0,34$ \\
\hline ТВTС $1 \mu \mathrm{g} / \mathrm{Kg}$ & $3,33 \pm 0,05$ & $35,91 \pm 4,08$ & $8,63 \pm 0,40$ & $4,88 \pm 0,16$ \\
\hline TВTC $5 \mu \mathrm{g} / \mathrm{Kg}$ & $3,21 \pm 0,09$ & $33,18 \pm 1,38$ & $9,14 \pm 0,19$ & $4,64 \pm 0,27$ \\
\hline
\end{tabular}



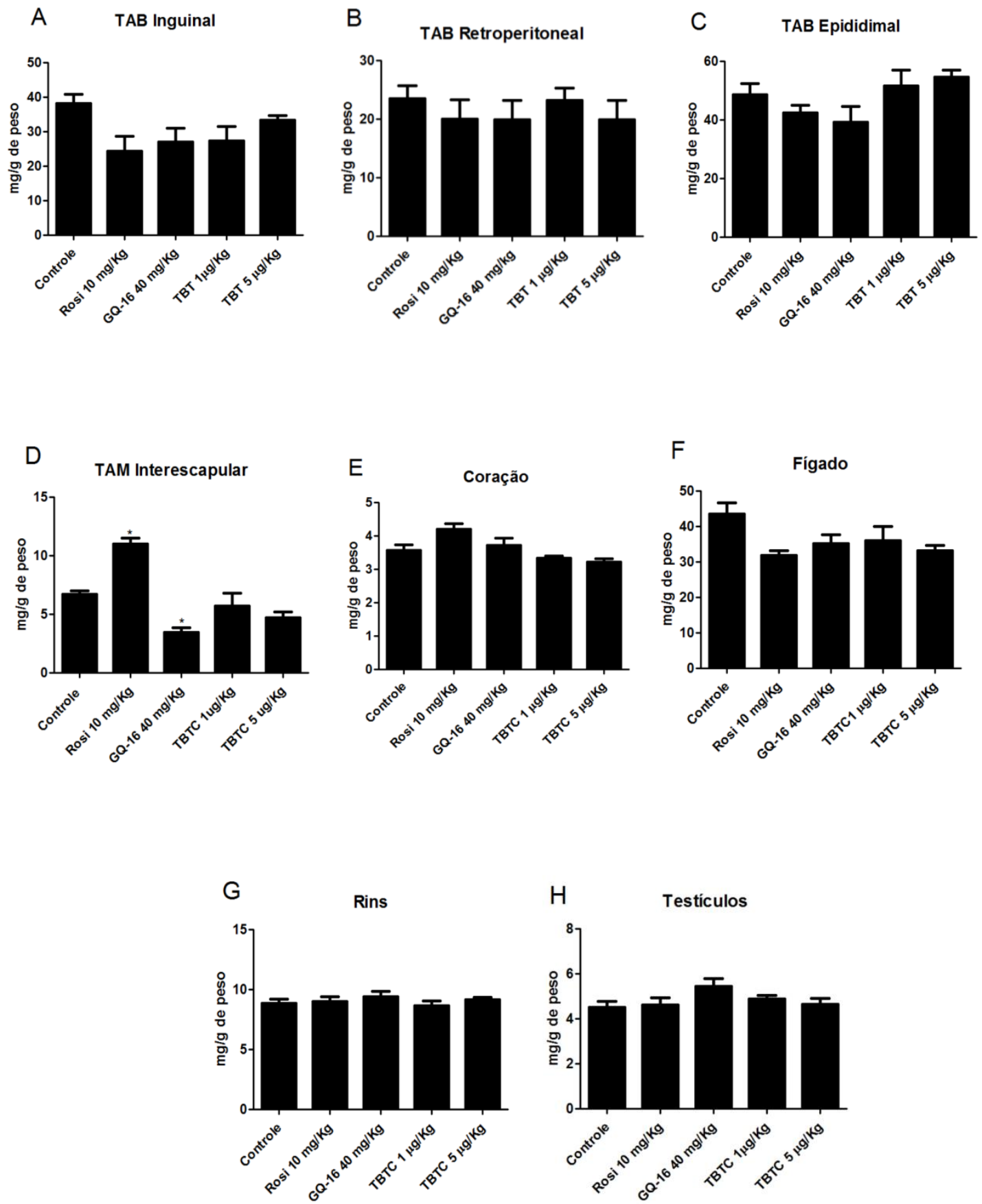

Figura 13. Massa dos tecidos e órgãos dos camundongos alimentados com dieta hiperlipídica. (A) Tecido Adiposo Branco (TAB) Inguinal, (B) Tecido Adiposo Branco (TAB) Retroperitoneal, (C) Tecido Adiposo Branco (TAB) Epididimal. (D) Tecido Adiposo Marrom (TAM) interescapular, (E) Coração, (F) Fígado, (G) Rins, (H) Testículos ( $\mathrm{n}=5)$. O TAM (D) apresentou um aumento no grupo tratado com rosiglitazona e uma redução no grupo tratado com GQ-16. Nos demais tecidos e órgãos não houve diferença significativa. Dados apresentados como média \pm EPM. Análise de variância (ANOVA) de um fator seguida do teste de Bonferroni. * $p<0,05$ vs controle. Figura 13A $p=0,1075$, Figura 13B $p=0,8459$, Figura 13C $p=0,4209$, Figura 13D $p=0,0981$, Figura 13E $p=0,1382$, Figura 13F $p=0,1719$, Figura 13G $p=0,6642$ e Figura $13 \mathrm{H} p=0,7329$. 


\subsection{AVALIAÇÃO DAS CARACTERÍSTICAS HISTOLÓGICAS DO TECIDO ADIPOSO DOS ANIMAIS ALIMENTADOS COM DIETA HIPERLIPÍDICA}

A análise histológica foi realizada apenas dos tecidos dos animais alimentados com dieta hiperlipídica. Foram analisados os tecidos adiposos branco inguinal, branco epididimal e marrom interescapular e tecido hepático.

Com o intuito de utilizar um critério de validação e excluir a possibilidade da avaliação sugestionada por parte do pesquisador, foi utilizada uma análise cega (ocultação do nomes do objeto de estudo) feita por 3 alunos do Programa de PósGraduação da UNB, escolhidos aleatoriamente. Os alunos foram orientados a classificar cada imagem de acordo com quantidade e diâmetro das vesículas de gordura em cada tecido, sem saber quais tecidos ou tratamentos tinham sido realizados. Os resultados estão apresentados na Ficha Avaliativa de Tecido (APÊNDICE A).

A análise do tecido adiposo marrom interescapular mostrou maior acúmulo lipídico nos tecidos pertencentes aos grupos tratados com rosiglitazona e com TBTC $5 \mu \mathrm{g} / \mathrm{Kg}$ de massa. Enquanto que o TAM dos animais tratados com rosiglitazona apresentou adipócitos maiores comparado ao grupo controle, o TAM dos animais que receberam TBTC $5 \mu \mathrm{g} / \mathrm{Kg}$ apresentou adipócitos pequenos, porém mais numerosos. (Figura 14B e 14E, respectivamente). 
A

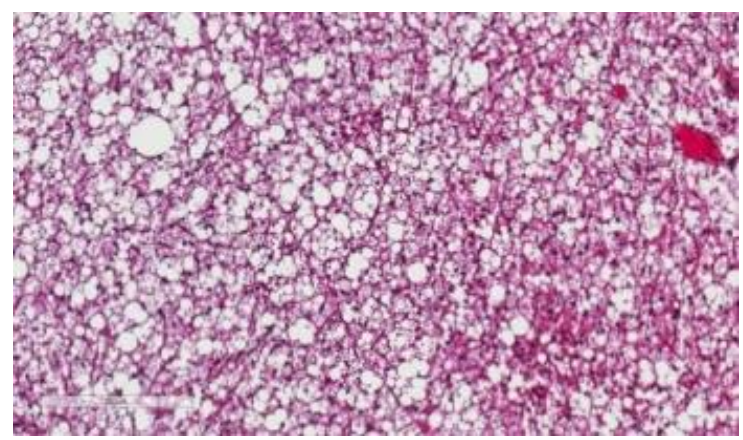

Controle

C

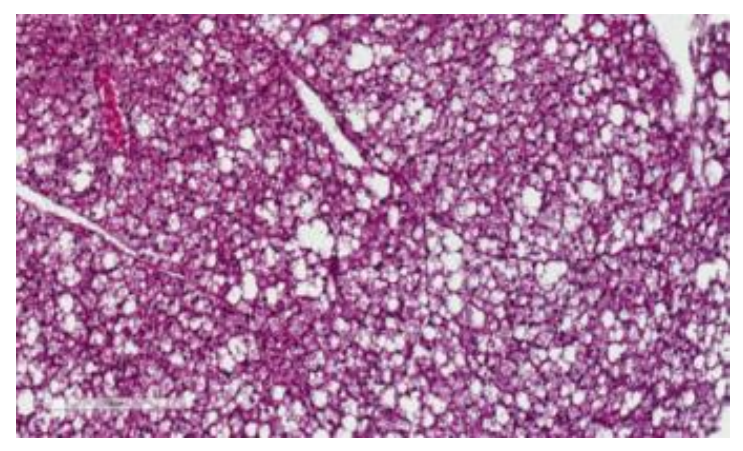

GQ-16 40 mg/Kg

E

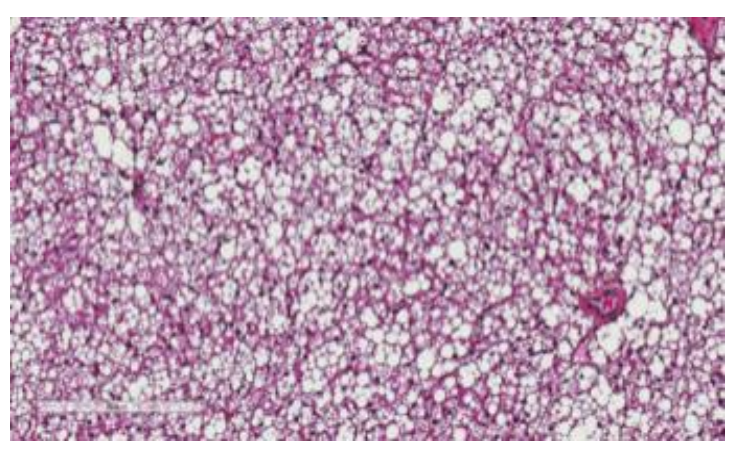

TBTC $5 \mu \mathrm{g} / \mathrm{Kg}$
B

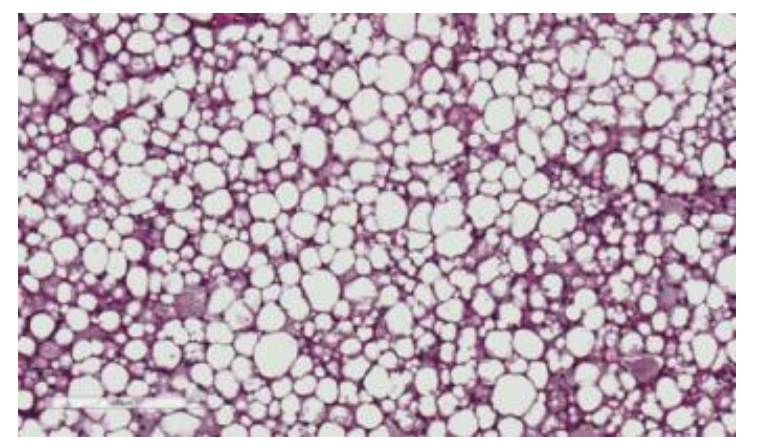

Rosiglitazona $10 \mathrm{mg} / \mathrm{Kg}$

D

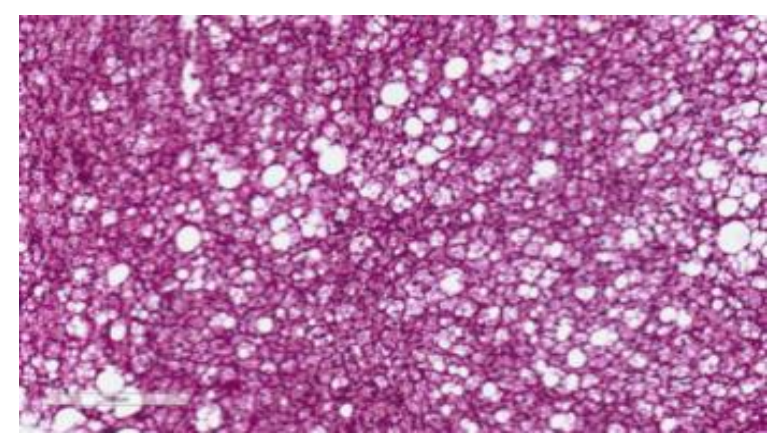

TBTC $1 \mu \mathrm{g} / \mathrm{Kg}$ 
epididimal não mostrou diferença entre os grupos tratados em relação ao grupo controle (Figura 16).

A

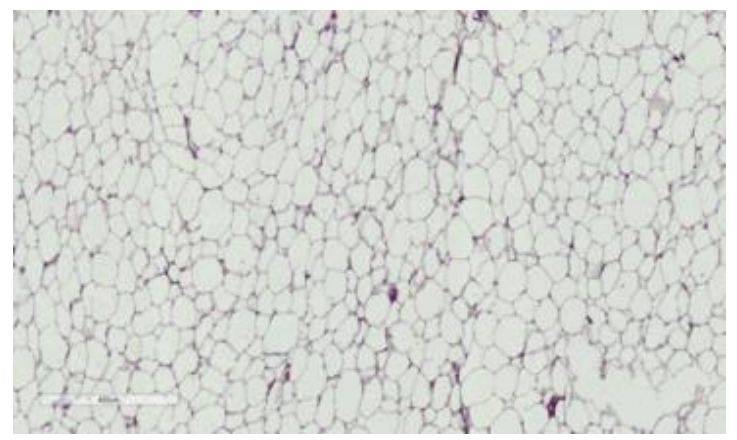

Controle

C

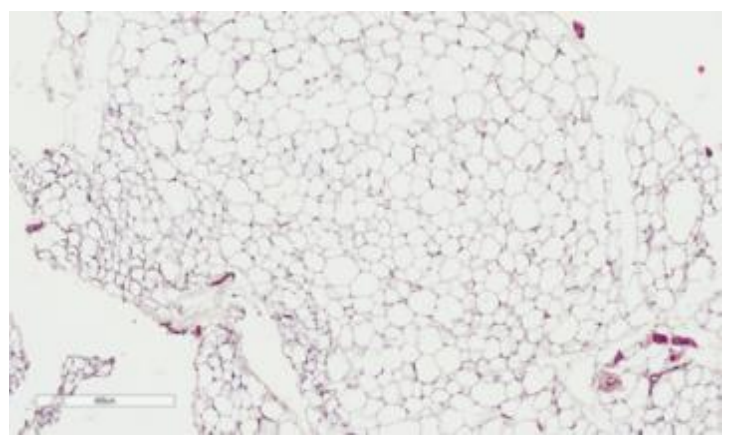

GQ-16 $40 \mathrm{mg} / \mathrm{Kg}$

E

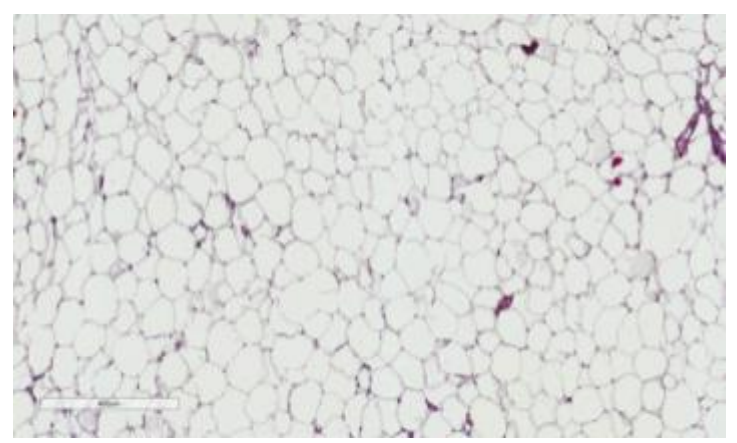

TBTC $5 \mu \mathrm{g} / \mathrm{Kg}$
B

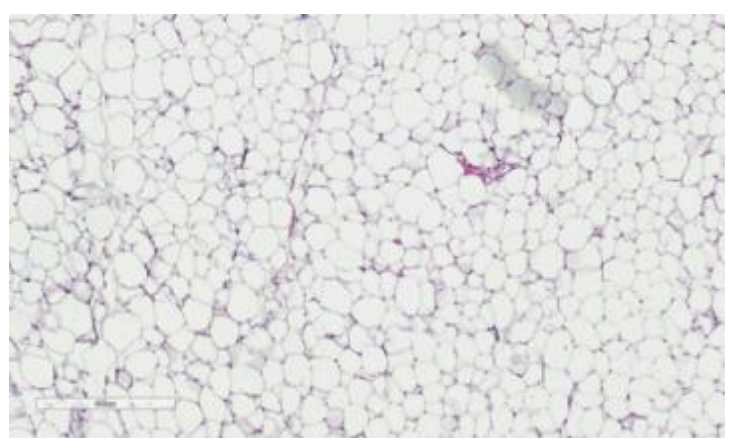

Rosiglitazona 10 mg/Kg

D

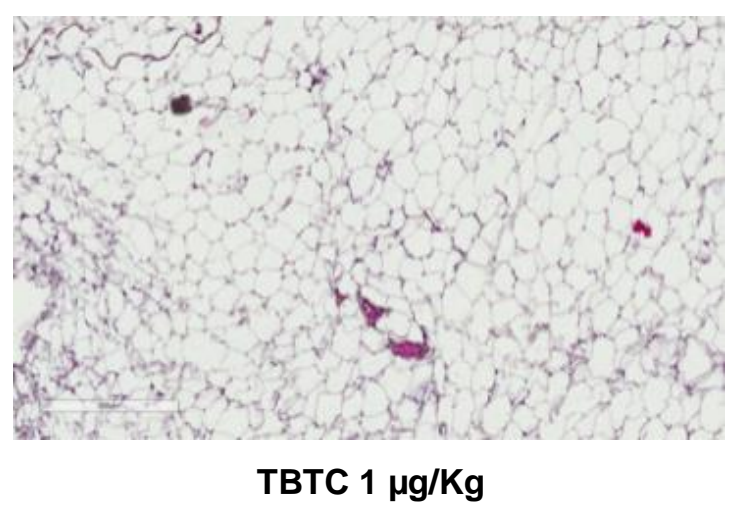


A

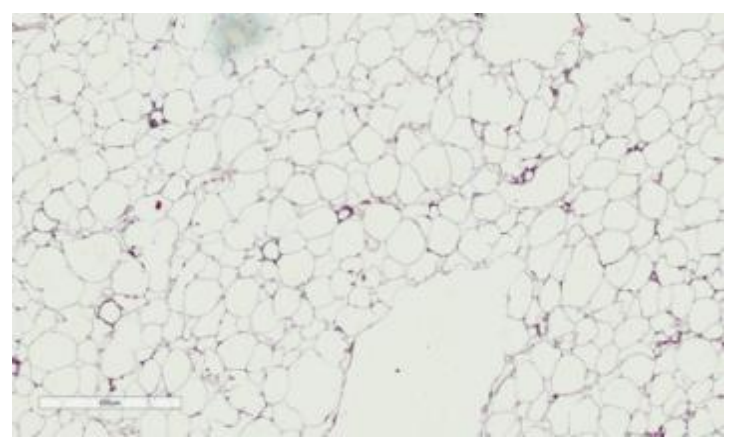

Controle

C

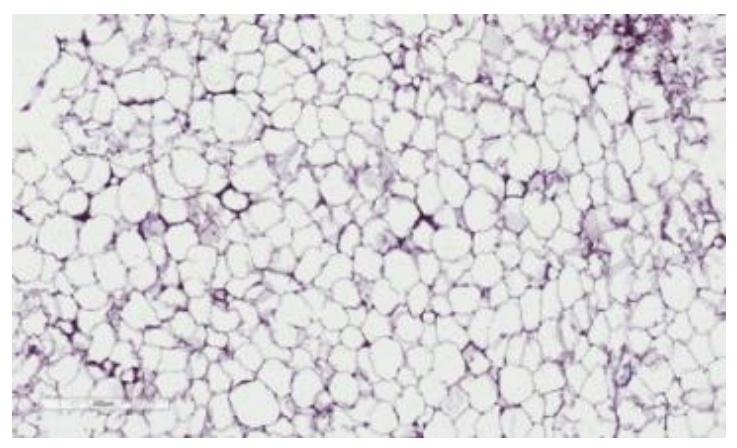

GQ-16 $40 \mathrm{mg} / \mathrm{Kg}$

E

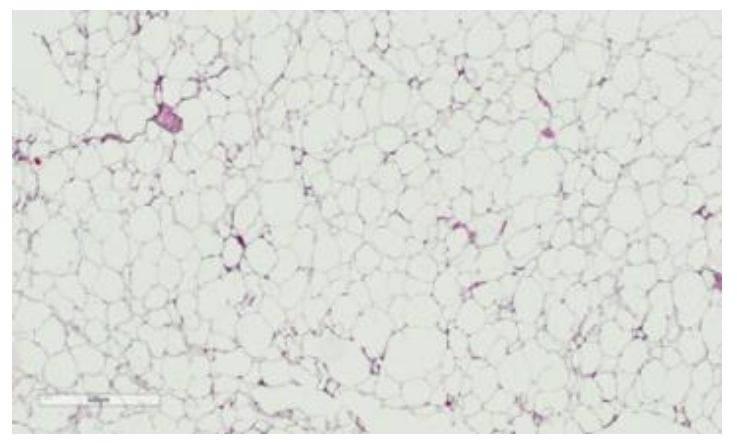

TBTC $5 \mu \mathrm{g} / \mathrm{Kg}$
B

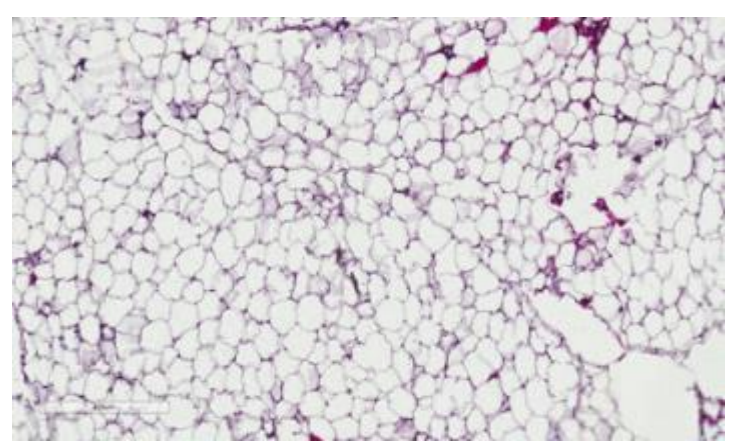

Rosiglitazona $10 \mathrm{mg} / \mathrm{Kg}$

D

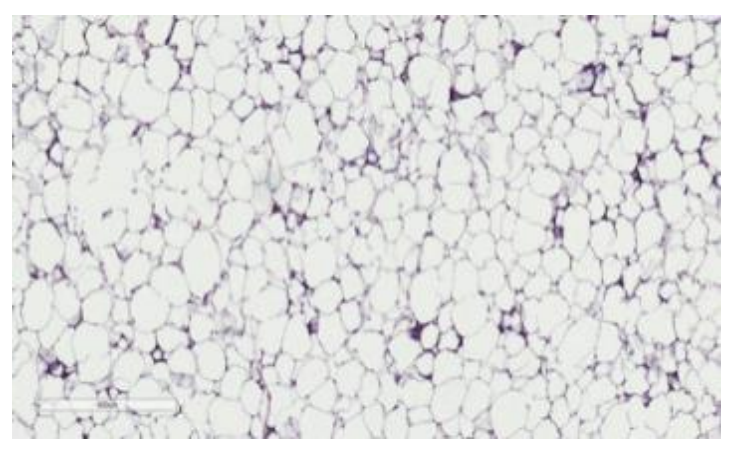

TBTC $1 \mu \mathrm{g} / \mathrm{Kg}$ 
5.10 AVALIAÇÃO DAS CARACTERÍSTICAS HISTOLÓGICAS DO TECIDO HEPÁTICO DOS ANIMAIS ALIMENTADOS COM DIETA HIPERLIPÍDICA

No tecido hepático foi observado uma maior quantidade de gotículas lipídicas nos hepatócitos, do grupo tratado com rosiglitazona (Figura 17B) e TBTC $5 \mu \mathrm{g} / \mathrm{Kg}$ (Figura 17E), sendo mais acentuado nos animais tratados com TBTC.

A

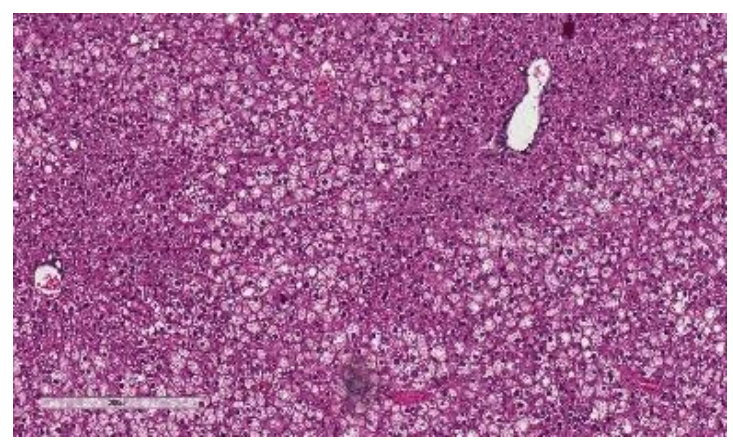

Controle

C

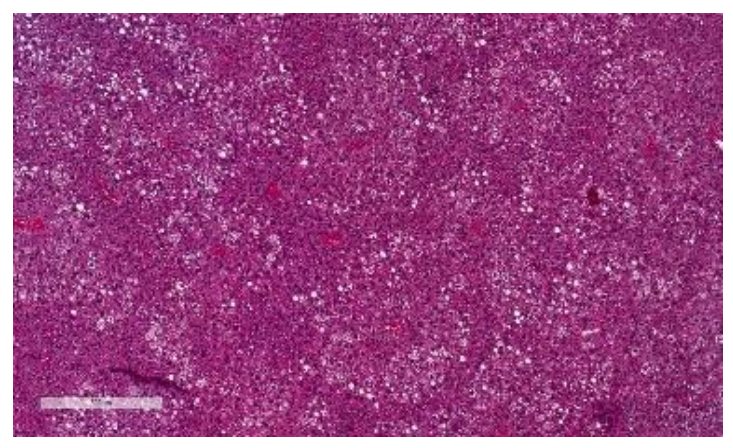

GQ-16 $40 \mathrm{mg} / \mathrm{Kg}$

E

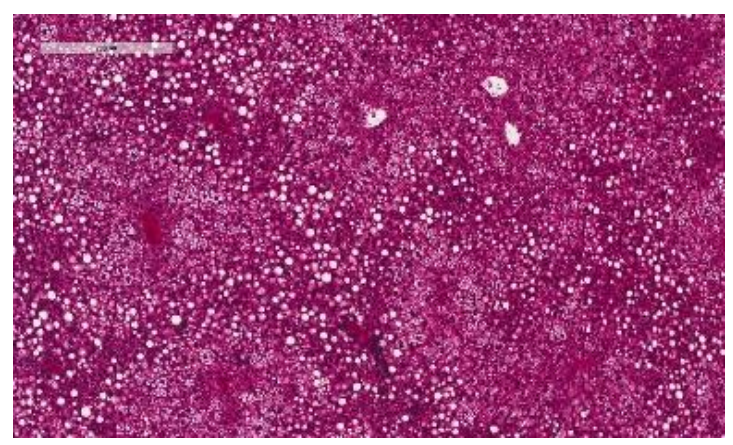

TBTC $5 \mu \mathrm{g} / \mathrm{Kg}$
B

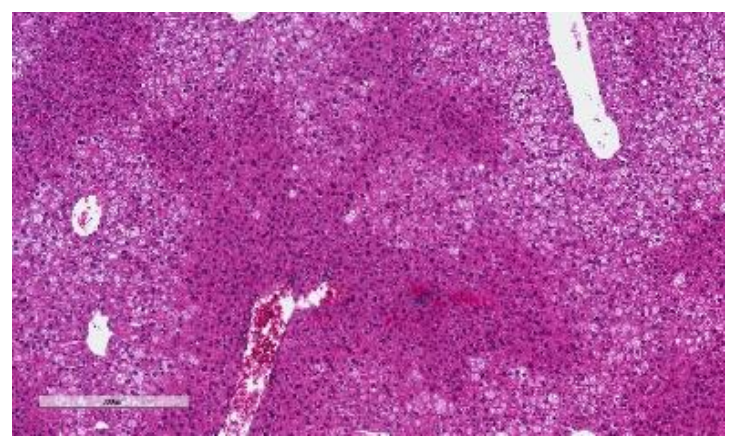

Rosiglitazona 10 mg/Kg

D

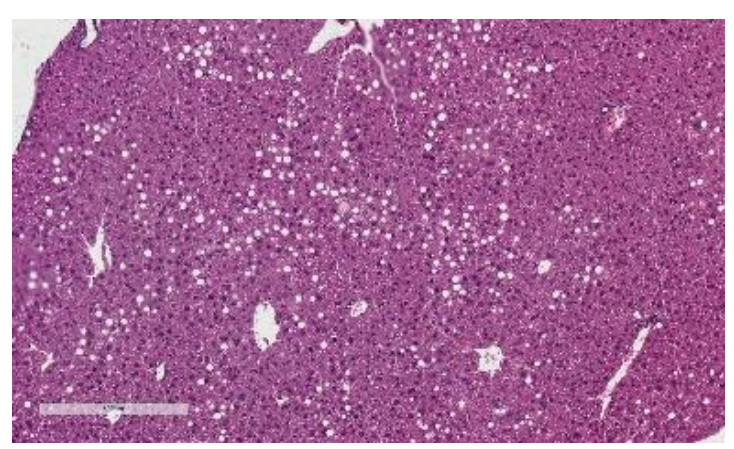

TBTC $1 \mu \mathrm{g} / \mathrm{Kg}$ 


\section{DISCUSSÃO}

A obesidade vem tornando-se uma epidemia crescente e global (129) e é um fator de risco para doenças não transmissíveis como doenças cardiovasculares, diabetes, distúrbios musculoesqueléticos, assim como de alguns tipos de câncer (130). Baillie-Hamilton foi a primeira autora a associar o lançamento de produtos químicos no meio ambiente e o aumento da incidência da obesidade (7), mostrando que uma exposição crônica a estes produtos poderia resultar em uma epidemia de obesidade e distúrbios a ela associados.

Dentre estes produtos químicos estão os desreguladores endócrinos, que podem causar doenças metabólicas, como a obesidade e diabetes (6). Frequentemente, as pessoas estão expostas a estes DE e em concentrações desconhecidas, portanto o intuito desta dissertação foi mimetizar esta possível exposição. Utilizamos dois modelos experimentais, animais alimentados com dieta normolípídica ou hiperlipídica e administrou-se um DE, o cloreto de tributilestanho (TBTC), diluído na água ou incorporado à dieta.

Nos animais alimentados com a dieta normolipídica administrou-se o TBTC em 3 concentrações $(1,5$ ou $25 \mu \mathrm{g} / \mathrm{Kg})$ e nos animais alimentados com a dieta hiperlipídica foram tratatos com TBTC em 2 concentrações (1 ou $5 \mu \mathrm{g} / \mathrm{Kg}$ ) ou rosiglitazona $10 \mathrm{mg} / \mathrm{Kg}$ ou GQ-16 $40 \mathrm{mg} / \mathrm{Kg}$. A rosiglitazona, utilizada como sensibilizador insulínico, apresenta efeitos desfavoráveis, como ganho de peso (131), por outro lado o GQ-16 apresenta um agonismo seletivo para o receptor PPARy, sendo capaz de aumentar o acúmulo intracelular de lipídios porém com uma menor intensidade que a rosiglitazona (105). Utilizou-se o GQ-16 também como controle, por ser um agonista parcial de PPARy semelhante ao composto TBTC, objeto de investigação neste trabalho.

Estudos relatam que o TBTC ativa o heterodímero RXR/PPARy e promove a adipogênese $(17,32,64)$. O RXR/PPARy desempenha um papel fundamental na diferenciação de adipócitos e armazenamento de energia e é, portanto, uma chave para o controle do metabolismo do corpo inteiro (73). 
Nossos resultados mostraram que não houve diferença estatisticamente significante entre as massas corporais médias dos camundongos que receberam diferentes tipos de tratamento quando comparadas a dos animais dos grupos controle, mas no modelo experimental em que os camundongos foram alimentados com dieta normolipídica, observou-se uma tendência de aumento na massa corporal dos animais que foram tratados com TBTC, na concentração de $5 \mu \mathrm{g} / \mathrm{Kg}$, diluído na água de beber. Zuo et al., 2011, administraram o TBTC por gavagem em animais alimentados com dieta padrão e mostrou um aumento significativo na massa corporal com a mesma concentração de $5 \mu \mathrm{g} / \mathrm{Kg}$ (34), Penza et al., 2011, determinaram um valor significativo na razão de massa de gordura pela massa corporal dos animais, em uma concentração de TBTC $0,5 \mu \mathrm{g} / \mathrm{Kg}$ administrando o TBTC incorporado à dieta padrão livre de soja (123). Neste trabalho, porém, quando TBTC a $5 \mu \mathrm{g} / \mathrm{Kg}$ foi administrado incorporado à dieta hiperlipídica, não foi observado o mesmo ganho de massa corporal. Neste modelo experimental, o tratamento com GQ-16 mostrou uma tendência de menor ganho de massa, similar aos resultados apresentados por Coelho et al., 2016 que administraram o GQ-16 em animais alimentados com dieta hiperlipídica (106).

No modelo experimental em que os animais foram alimentados com uma dieta normolipídica e expostos ao TBTC, a glicemia capilar não apresentou diferença entre os grupos, sugerindo que por meio dessa forma de administração, o TBTC não promoveu alteração nos níveis glicêmicos. Entretanto, no modelo onde os animais foram induzidos à hiperglicemia por dieta hiperlipídica, e posteriormente iniciado o tratamento, a rosiglitazona diminuiu significativamente os níveis glicêmicos. O GQ-16 apresentou uma tendência de diminuição, mostrando que nosso controle positivo foi efetivo, enquanto que o tratamento com o TBTC manteve os níveis semelhantes ao controle sugerindo que o TBTC não altera os níveis de glicemia capilar neste modelo de estudo.

Agonistas totais de PPARy, como a rosiglitazona e parciais como o GQ-16, além de promoverem sensibilização à insulina, $(105,132)$ tem a capacidade de induzir o "amarronzamento" do tecido adiposo branco, isto é, conferir aos adipócitos brancos características fenotípicas dos adipócitos marrons (133).

Em relação à massa do tecido adiposo marrom interescapular, no nosso estudo, houve uma diferença estatisticamente significante entre os animais tratados 
com rosiglitazona e GQ-16 quando comparados aos animais do grupo controle e uma tendência de diminuição nos animais tratados com TBTC $5 \mu \mathrm{g} / \mathrm{Kg}$. Os animais tratados com rosiglitazona apresentaram uma massa de TAM maior que o grupo controle enquanto os animais tratados com GQ-16 apresentaram uma massa menor que os animais do grupo controle, estes resultados corroboram com os achados em Coelho et al. Na análise morfológica cega das lâminas, foi possível observar gotas lipídicas maiores no TAM dos animais tratados com a rosiglitazona e mais numerosas nos animais tratados com TBTC $5 \mu \mathrm{g} / \mathrm{Kg}$.

Nos nossos estudos, não houve diferença significativa entre os grupos, na massa dos tecidos adiposos brancos, mostrando que o tratamento não interferiu no aumento da massa dos tecidos, porém Grun et al., 2006, associaram a exposição in utero do TBTC a um ganho na massa adiposa do tecido epididimal de aproximadamente $20 \%$ maior que o controle (32).

No tecido adiposo inguinal, na análise morfológica, observou-se adipócitos ligeiramente menores no grupo tratado com GQ-16, semelhante ao observado por Coelho et al., 2016 além disso, observaram a expressão de genes termogênicos no TAB, sugerindo o "amarronzamento" do tecido em decorrência do tratamento. (106). Adicionalmente, foi observado também um discreto aumento nos adipócitos do grupo exposto ao TBTC $5 \mu \mathrm{g} / \mathrm{Kg}$, sugerindo que o composto TBTC promove maior acúmulo de lipídios e como consequência apresenta aumento no tamanho das células adiposas.

Neste trabalho, não foi observada diferença entre as massas dos testículos entre os grupos nos dois modelos experimentais. No trabalho de Chen et al., 2008, os camundongos foram tratados com TBTC $(0,5,5$ ou $50 \mu \mathrm{g} / \mathrm{Kg})$ por gavagem e, em concentrações mais elevadas foi detectada uma redução na massa dos testículos, em valores absolutos e relativos, além disso, foi observado alterações na espermatogênese dos camundongos tratados com TBTC (134).

A hepatoxidade do TBTC pode ser acarretada pela inibição do citocromo P450 fazendo com que ocorra uma diminuição do metabolismo hepático (135), dessa forma avaliaram-se a massa e a histologia do tecido hepático dos animais alimentados com a dieta hiperlipídica. Nossos resultados não mostraram diferença entre as massas do tecido hepático, porém, foi observado uma maior quantidade de gotas lipídicas nos hepatócitos do grupo tratado com rosiglitazona e mais acentuado no grupo tratado 
com TBTC $5 \mu \mathrm{g} / \mathrm{Kg}$, sugerindo que a rosiglitazona e o TBTC são capazes de promover um maior acúmulo de gordura no tecido hepático. Resultados que corroboram com os nossos achados foram descritos por Zuo et al., 2011, que mostraram o desenvolvimento de esteatose hepática em camundongos na concentração de TBTC $5 \mu \mathrm{g} / \mathrm{Kg}(34)$.

O TBTC, mesmo sendo um agonista parcial de PPARy, no nosso estudo não mostrou os efeitos esperados de um agonista de PPARy como ganho de massa e redução da glicemia. Foi mostrado, in vitro, que o TBTC além de ser agonista de PPARy também é um agonista total de RXR $(19,32)$. Como o RXR pode se heterodimerizar com outros receptores como TR (receptores de hormônio tireoidiano), o VDR (receptor da vitamina D) e o RAR (receptor do ácido retinoico) $(110,136)$, o TBTC poderia estar ativando o RXR quando ele está heterodimerizado com outros receptores e desta forma poderia acabar ativando outras vias metabólicas. O TBTC também pode ativar ou bloquear a ação de outros receptores, como observado em dados preliminares e não publicados do Laboratoratório de Farmacologia da Universidade de Brasília, que mostram que o TBTC pode ser um antagonista do receptor PPARa, o que poderia ajudar a explicar os nossos resultados.

No nosso estudo não foram avaliados efeitos transgeracionais, ChamorroGarcia et al., 2013, mostraram resultados de maiores efeitos do TBTC observados após exposição pré-natal, podendo alterar a programação do metabolismo em camundongos das gerações e predispor células-tronco mesenquimais multipotentes para se tornarem células adiposas, chamado de efeito transgeracional (16).

O efeito direto e agudo do TBTC foi investigado no nosso estudo, em animais alimentados de duas formas diferentes, dieta normolipídica ou hiperlipídica. No estudo de Zuo et al., 2011, o TBTC foi administrado por gavagem em camundongos Kun Ming (KM) alimentados somente com dieta padrão, mostrando na concentração de TBTC 5 $\mu \mathrm{g} / \mathrm{Kg}$, um significativo ganho de massa e sugerindo uma resistência à insulina (34). Não obstante, Zuo não descreveu presença de hiperglicemia, o que nos instigou a investigar os efeitos do TBTC na glicose, distribuição e morfologia do tecido adiposo dos animais tratados em duas concentrações distintas.

Nas condições deste estudo, o tratamento com o TBTC não foram encontradas diferenças estatisticamente significantes quanto ao ganho de massa e hiperglicemia. Todavia, foi observado um acúmulo de lipídios no fígado de animais 
alimentados com dieta hiperlipídica. Com o intuito de complementar estes achados foi colocado como meta quantificar o TBTC absorvido nos tecidos nos tecidos dos animais, bem como os compostos (GQ-16 e rosiglitazona) utilizados nessa dissertação, como controle. 


\section{CONCLUSÃO}

Os resultados sugerem que o TBTC não altera o consumo de dieta e água, tanto em animais alimentados com a dieta normolipídica quanto hiperlipídica. Embora o TBTC não tenha apresentado diferença estatisticamente significante em relação ao ganho de massa entre os grupos, revelou uma tendência de maior ganho de massa na concentração de $5 \mu \mathrm{g} / \mathrm{Kg}$ em animais alimentados com a dieta normolipídica. Apesar do TBTC não ter alterado os níveis glicêmicos nas duas situações, em animais alimentados com os dois tipos de dietas, o TBTC na concentração de $5 \mu \mathrm{g} / \mathrm{Kg}$ foi capaz de promover acúmulo de lipídios nos hepatócitos dos animais alimentados com a dieta hipelipídica sugerindo que o TBTC é um promotor de esteatose hepática em camundongos. Apesar de ser um agonista parcial de PPARy, o TBTC não melhorou os níveis glicêmicos dos animais alimentados com a dieta hiperlipídica, ao contrário de outros agonistas parciais como o GQ-16. Para continuar o estudo e complementar os resultados apresentados nesta dissertação, uma perspectiva relevante seria mensurar a concentração do TBTC absorvida nos tecidos dos animais. 


\section{REFERÊNCIAS}

1. Hoch M. Organotin compounds in the environment - an overview. Applied Geochemistry. 2001;16:719-43.

2. Vasseur $\mathrm{P}$, Cossu-Leguille $\mathrm{C}$. Linking molecular interactions to consequent effects of persistent organic pollutants (POPs) upon populations. Chemosphere. 2006;62(7):1033-42.

3. La Merrill M, Emond C, Kim MJ, Antignac JP, Le Bizec B, Clement K, et al. Toxicological function of adipose tissue: focus on persistent organic pollutants. Environmental health perspectives. 2013;121(2):162-9.

4. Tabb MM, Blumberg B. New modes of action for endocrine-disrupting chemicals. Molecular endocrinology (Baltimore, Md). 2006;20(3):475-82.

5. Schug TT, Janesick A, Blumberg B, Heindel JJ. Endocrine disrupting chemicals and disease susceptibility. The Journal of steroid biochemistry and molecular biology. 2011;127(3):204-15.

6. Casals-Casas C, Desvergne B. Endocrine disruptors: from endocrine to metabolic disruption. Annual review of physiology. 2011;73:135-62.

7. Baillie-Hamilton PF. Chemical toxins: a hypothesis to explain the global obesity epidemic. Journal of alternative and complementary medicine (New York, NY). 2002;8(2):185-92.

8. Ruzzin J, Petersen R, Meugnier E, Madsen L, Lock EJ, Lillefosse H, et al. Persistent organic pollutant exposure leads to insulin resistance syndrome. Environ Health Perspect. 2010;118(4):465-71.

9. Alonso-Magdalena P, Vieira E, Soriano S, Menes L, Burks D, Quesada I, et al. Bisphenol A exposure during pregnancy disrupts glucose homeostasis in mothers and adult male offspring. Environ Health Perspect. 2010;118(9):1243-50.

10. Lee DH, Steffes MW, Sjodin A, Jones RS, Needham LL, Jacobs DR, Jr. Low dose organochlorine pesticides and polychlorinated biphenyls predict obesity, dyslipidemia, and insulin resistance among people free of diabetes. PLoS One. 2011;6(1):e15977. 
11. Lim JS, Lee DH, Jacobs DR, Jr. Association of brominated flame retardants with diabetes and metabolic syndrome in the U.S. population, 2003-2004. Diabetes Care. 2008;31(9):1802-7.

12. Ukropec J, Radikova Z, Huckova M, Koska J, Kocan A, Sebokova E, et al. High prevalence of prediabetes and diabetes in a population exposed to high levels of an organochlorine cocktail. Diabetologia. 2010;53(5):899-906.

13. Appel KE. Organotin compounds: toxicokinetic aspects. Drug metabolism reviews. 2004;36(3-4):763-86.

14. Fent K. Ecotoxicology of organotin compounds. Critical reviews in toxicology. 1996;26(1):1-117.

15. Pereira-Fernandes A, Vanparys C, Hectors TL, Vergauwen L, Knapen D, Jorens $P G$, et al. Unraveling the mode of action of an obesogen: mechanistic analysis of the model obesogen tributyltin in the 3T3-L1 cell line. Molecular and cellular endocrinology. 2013;370(1-2):52-64.

16. Chamorro-García R, Sahu M, Abbey RJ, Laude J, Pham N, Blumberg B. Transgenerational inheritance of increased fat depot size, stem cell reprogramming, and hepatic steatosis elicited by prenatal exposure to the obesogen tributyltin in mice. Environmental Health Perspectives (Online). 2013;121(3):359.

17. Li X, Ycaza J, Blumberg B. The environmental obesogen tributyltin chloride acts via peroxisome proliferator activated receptor gamma to induce adipogenesis in murine 3T3-L1 preadipocytes. The Journal of steroid biochemistry and molecular biology. 2011;127(1-2):9-15.

18. Inadera $\mathrm{H}$, Shimomura $\mathrm{A}$. Environmental chemical tributyltin augments adipocyte differentiation. Toxicol Lett. 2005;159(3):226-34.

19. le Maire A, Grimaldi M, Roecklin D, Dagnino S, Vivat-Hannah V, Balaguer P, et al. Activation of RXR-PPAR heterodimers by organotin environmental endocrine disruptors. EMBO reports. 2009;10(4):367-73.

20. Biemann R, Fischer B, Bluher M, Navarrete Santos A. Tributyltin affects adipogenic cell fate commitment in mesenchymal stem cells by a PPARgamma independent mechanism. Chem Biol Interact. 2014;214:1-9. 
21. Gabbianelli R, Falcioni G, Lupidi G. Effect of organotin compounds on trout AMP-deaminases. Applied organometallic chemistry. 2002;16(1):3-8.

22. EPA (Environmental Protection Agency). Endocrine Disruption US: Last updated on August 18, 2016; 2016 [cited 2016 01/11/2016]. Available from: https://www.epa.gov/endocrine-disruption/what-endocrine-disruption.

23. Kavlock RJ, Daston GP, DeRosa C, Fenner-Crisp P, Gray LE, Kaattari S, et al. Research needs for the risk assessment of health and environmental effects of endocrine disruptors: a report of the US EPA-sponsored workshop. Environmental health perspectives. 1996;104(Suppl 4):715.

24. Damstra T, Barlow S, Bergman A, Kavlock R, Van Der Kraak G. Global assessment of the state-of-the-science of endocrine disruptors. Geneva: World Health Organization. 2002.

25. Tang-Péronard JL, Andersen HR, Jensen TK, Heitmann BL. Endocrinedisrupting chemicals and obesity development in humans: A review. obesity reviews. 2011;12(8):622-36.

26. NIH (National Institute of Environmental Health Science). Endocrine Disruptors 2016. Available from: https://www.niehs.nih.gov/health/topics/agents/endocrine/.

27. Neel BA, Sargis RM. The paradox of progress: environmental disruption of metabolism and the diabetes epidemic. Diabetes. 2011;60(7):1838-48.

28. Flegal KM, Carroll MD, Kit BK, Ogden CL. Prevalence of obesity and trends in the distribution of body mass index among US adults, 1999-2010. Jama. 2012;307(5):491-7.

29. Heindel JJ, vom Saal FS. Role of nutrition and environmental endocrine disrupting chemicals during the perinatal period on the aetiology of obesity. Molecular and cellular endocrinology. 2009;304(1):90-6.

30. Newbold RR. Impact of environmental endocrine disrupting chemicals on the development of obesity. Hormones (Athens). 2010;9(3):206-17.

31. Manikkam M, Tracey R, Guerrero-Bosagna C, Skinner MK. Plastics derived endocrine disruptors (BPA, DEHP and DBP) induce epigenetic transgenerational 
inheritance of obesity, reproductive disease and sperm epimutations. PLOS one. 2013;8(1):e55387.

32. Grun F, Watanabe H, Zamanian Z, Maeda L, Arima K, Cubacha R, et al. Endocrine-disrupting organotin compounds are potent inducers of adipogenesis in vertebrates. Molecular endocrinology (Baltimore, Md). 2006;20(9):2141-55.

33. Hao C, Cheng X, Xia H, Ma X. The endocrine disruptor mono-(2-ethylhexyl) phthalate promotes adipocyte differentiation and induces obesity in mice. Bioscience reports. 2012;32(6):619-29.

34. Zuo Z, Chen S, Wu T, Zhang J, Su Y, Chen Y, et al. Tributyltin causes obesity and hepatic steatosis in male mice. Environmental toxicology. 2011;26(1):79-85.

35. Grun F, Blumberg B. Perturbed nuclear receptor signaling by environmental obesogens as emerging factors in the obesity crisis. Reviews in endocrine \& metabolic disorders. 2007;8(2):161-71.

36. Grun F, Blumberg B. Environmental obesogens: organotins and endocrine disruption via nuclear receptor signaling. Endocrinology. 2006;147(6 Suppl):S50-5.

37. Kirchner S, Kieu T, Chow C, Casey S, Blumberg B. Prenatal exposure to the environmental obesogen tributyltin predisposes multipotent stem cells to become adipocytes. Molecular endocrinology (Baltimore, Md). 2010;24(3):526-39.

38. Alonso-Magdalena P, Quesada I, Nadal A. Endocrine disruptors in the etiology of type 2 diabetes mellitus. Nature Reviews Endocrinology. 2011;7(6):346-53.

39. Lee D-H, Steffes MW, Sjödin A, Jones RS, Needham LL, Jacobs Jr DR. Low dose of some persistent organic pollutants predicts type 2 diabetes: a nested casecontrol study. Environmental health perspectives. 2010;118(9):1235.

40. Hock M. Organotin componds in the environment - an overview. Applied Geochimestry. 2001;16:710-43.

41. ATSDR (Agency for toxic substances and disease registry) Toxicological profile for tin and tin compounds. U.S. US DEPARTMENT OF HEALTH AND HUMAN SERVICES 2016 [cited 2016 22/11/2016]. Available from: https://www.atsdr.cdc.gov/toxprofiles/tp55.pdf. 
42. Blunden SJ, Evans CJ. Organotin compounds. Anthropogenic Compounds: Springer; 1990. p. 1-44.

43. Piver WT. Organotin compounds: industrial applications and biological investigation. Environmental health perspectives. 1973;4:61-79.

44. Clark EA, Sterritt RM, Lester JN. The fate of tributyltin in the aquatic environment. Environmental science \& technology. 1988;22(6):600-4.

45. Perina F. Avaliação da toxicidade de biocidas utilizados em tintas antiincrustantes: Dissertação (Mestrado em Oceanografia Física, Química e Geológica)Universidade Federal do Rio Grande-FURG, Rio Grande, 138p; 2009.

46. Evans WH, Cardarelli NF, Smith DJ. Accumulation and excretion of [1$14 \mathrm{C}]$ bis(tri-n-butyltin) oxide in mice. Journal of toxicology and environmental health. $1979 ; 5(5): 871-7$.

47. Valenzuela A, Lespes G, Quiroz W, Aguilar LF, Bravo MA. Speciation analysis of organotin compounds in human urine by headspace solid-phase micro-extraction and gas chromatography with pulsed flame photometric detection. Talanta. 2014;125:196-203.

48. Rantakokko P, Turunen A, Verkasalo PK, Kiviranta H, Männistö S, Vartiainen T. Blood levels of organotin compounds and their relation to fish consumption in Finland. Science of the total environment. 2008;399(1):90-5.

49. Seligman P, Maguire R, Lee R, Hinga K, Valkirs A, Stang P. Persistence and fate of tributyltin in aquatic ecosystems. Organotin: Springer; 1996. p. 429-57.

50. Gibbs PE, Bryan G, Pascoe P, Burt G. The use of the dog-whelk, Nucella lapillus, as an indicator of tributyltin (TBT) contamination. Journal of the Marine Biological Association of the United Kingdom. 1987;67(03):507-23.

51. Santillo D, Johnston P, Langston WJ. 13. Tributyltin (TBT) antifoulants: a tale of ships, snails and imposex. Late lessons from early warnings: the precautionary principle 1896-2000. 2001:135.

52. Abidli S, Santos MM, Lahbib Y, Castro LFC, Reis-Henriques MA, El Menif NT. Tributyltin (TBT) effects on Hexaplex trunculus and Bolinus brandaris (Gastropoda: 
Muricidae): imposex induction and sex hormone levels insights. Ecological Indicators. 2012;13(1):13-21.

53. Gibbs P, Bryan G, Pascoe P. TBT-induced imposex in the dogwhelk, Nucella lapillus: geographical uniformity of the response and effects. Marine environmental research. 1991;32(1):79-87.

54. Spooner N, Gibbs P, Bryan G, Goad L. The effect of tributyltin upon steroid titres in the female dogwhelk, Nucella lapillus, and the development of imposex. Marine Environmental Research. 1991;32(1):37-49.

55. Santos MM, Castro LF, Vieira MN, Micael J, Morabito R, Massanisso P, et al. New insights into the mechanism of imposex induction in the dogwhelk Nucella lapillus. Comparative biochemistry and physiology Toxicology \& pharmacology : CBP. 2005;141(1):101-9.

56. IMO (International Maritime Organization) - Anti-fouling systems 2016 [cited 2016 22/11/2016]. Available from: http://www.imo.org/en/OurWork/Environment/AntifoulingSystems/Pages/Default.aspx.

57. BRASIL. MINISTÉRIO DO MEIO AMBIENTE - Conselho Nacional do Meio Ambiente - CONAMA. RESOLUÇÃO N 357, DE 17 DE MARÇO DE 2005 . Alterada pela Resolução 410/2009 e pela 430/2011. Dispõe sobre a classificação dos corpos de água e diretrizes ambientais para o seu enquadramento, bem como estabelece as condições e padrões de lançamento de efluentes, e dá outras providências Publicada no DOU nº 053, de 18/03/2005, págs. 58-63 [citada 2016 22/11/2016]. http://www.mma.gov.br/port/conama/res/res05/res35705.pdf.

58. He K, Zhang J, Chen Z. Effect of tributyltin on the food intake and brain neuropeptide expression in rats. Endokrynologia Polska. 2014;65(6):485-90.

59. Regnier SM, El-Hashani E, Kamau W, Zhang X, Massad NL, Sargis RM. Tributyltin differentially promotes development of a phenotypically distinct adipocyte. Obesity (Silver Spring, Md). 2015;23(9):1864-71.

60. Omura M, Ogata R, Kubo K, Shimasaki Y, Aou S, Oshima Y, et al. Twogeneration reproductive toxicity study of tributyltin chloride in male rats. Toxicological Sciences. 2001;64(2):224-32. 
61. Adeeko A, Li D, Forsyth DS, Casey V, Cooke GM, Barthelemy J, et al. Effects of in utero tributyltin chloride exposure in the rat on pregnancy outcome. Toxicological Sciences. 2003;74(2):407-15.

62. Kishta O, Adeeko A, Li D, Luu T, Brawer JR, Morales C, et al. In utero exposure to tributyltin chloride differentially alters male and female fetal gonad morphology and gene expression profiles in the Sprague-Dawley rat. Reproductive Toxicology. $2007 ; 23(1): 1-11$.

63. Hatch EE, Nelson JW, Qureshi MM, Weinberg J, Moore LL, Singer M, et al. Association of urinary phthalate metabolite concentrations with body mass index and waist circumference: a cross-sectional study of NHANES data, 1999-2002. Environmental Health. 2008;7(1):1.

64. Kanayama T, Kobayashi N, Mamiya S, Nakanishi T, Nishikawa J. Organotin compounds promote adipocyte differentiation as agonists of the peroxisome proliferator-activated receptor gamma/retinoid $X$ receptor pathway. Molecular pharmacology. 2005;67(3):766-74.

65. Hiromori Y, Nishikawa J-i, Yoshida I, Nagase H, Nakanishi T. Structuredependent activation of peroxisome proliferator-activated receptor (PPAR) $Y$ by organotin compounds. Chemico-biological interactions. 2009;180(2):238-44.

66. Yanik SC, Baker AH, Mann KK, Schlezinger JJ. Organotins are Potent Activators of PPARY and Adipocyte Differentiation in Bone Marrow Multipotent Mesenchymal Stromal Cells1. Toxicological Sciences. 2011:kfr140.

67. Robinson-Rechavi M, Escriva Garcia H, Laudet V. The nuclear receptor superfamily. Journal of cell science. 2003;116(Pt 4):585-6.

68. Sladek FM. What are nuclear receptor ligands? Molecular and cellular endocrinology. 2011;334(1-2):3-13.

69. Bourguet W, Germain P, Gronemeyer H. Nuclear receptor ligand-binding domains: three-dimensional structures, molecular interactions and pharmacological implications. Trends in pharmacological sciences. 2000;21(10):381-8.

70. Berger J, Moller DE. The mechanisms of action of PPARs. Annual review of medicine. 2002;53:409-35. 
71. Yong EL, Li J, Liu MH. Single gene contributions: genetic variants of peroxisome proliferator-activated receptor (isoforms alpha, beta/delta and gamma) and mechanisms of dyslipidemias. Current opinion in lipidology. 2008;19(2):106-12.

72. Monsalve FA, Pyarasani RD, Delgado-Lopez F, Moore-Carrasco R. Peroxisome proliferator-activated receptor targets for the treatment of metabolic diseases. Mediators of inflammation. 2013;2013:549627.

73. Evans RM, Barish GD, Wang YX. PPARs and the complex journey to obesity. Nature medicine. 2004;10(4):355-61.

74. Issemann I, Green S. Activation of a member of the steroid hormone receptor superfamily by peroxisome proliferators. Nature. 1990;347(6294):645-50.

75. Hiukka A, Maranghi M, Matikainen N, Taskinen MR. PPARalpha: an emerging therapeutic target in diabetic microvascular damage. Nature reviews Endocrinology. 2010;6(8):454-63.

76. Robciuc MR, Skrobuk P, Anisimov A, Olkkonen VM, Alitalo K, Eckel RH, et al. Angiopoietin-like 4 mediates PPAR delta effect on lipoprotein lipase-dependent fatty acid uptake but not on beta-oxidation in myotubes. PloS one. 2012;7(10):e46212.

77. Toral M, Romero M, Jimenez R, Mahmoud AM, Barroso E, Gomez-Guzman M, et al. Carnitine palmitoyltransferase-1 up-regulation by PPAR-beta/delta prevents lipidinduced endothelial dysfunction. Clinical science (London, England : 1979). 2015;129(9):823-37.

78. Janani C, Ranjitha Kumari BD. PPAR gamma gene--a review. Diabetes \& metabolic syndrome. 2015;9(1):46-50.

79. Feige JN, Gelman L, Michalik L, Desvergne B, Wahli W. From molecular action to physiological outputs: peroxisome proliferator-activated receptors are nuclear receptors at the crossroads of key cellular functions. Progress in lipid research. 2006;45(2):120-59.

80. Fajas L, Auboeuf D, Raspe E, Schoonjans K, Lefebvre AM, Saladin R, et al. The organization, promoter analysis, and expression of the human PPARgamma gene. The Journal of biological chemistry. 1997;272(30):18779-89. 
81. Yuan G, Chen X, Li D. Modulation of peroxisome proliferator-activated receptor gamma (PPAR gamma) by conjugated fatty acid in obesity and inflammatory bowel disease. Journal of agricultural and food chemistry. 2015;63(7):1883-95.

82. Fajas L, Fruchart JC, Auwerx J. PPARgamma3 mRNA: a distinct PPARgamma mRNA subtype transcribed from an independent promoter. FEBS letters. 1998;438(12):55-60.

83. Rosen ED, Sarraf P, Troy AE, Bradwin G, Moore K, Milstone DS, et al. PPAR gamma is required for the differentiation of adipose tissue in vivo and in vitro. Molecular cell. 1999;4(4):611-7.

84. Siersbaek R, Nielsen R, Mandrup S. PPARgamma in adipocyte differentiation and metabolism--novel insights from genome-wide studies. FEBS letters. 2010;584(15):3242-9.

85. Chawla A, Schwarz EJ, Dimaculangan DD, Lazar MA. Peroxisome proliferatoractivated receptor (PPAR) gamma: adipose-predominant expression and induction early in adipocyte differentiation. Endocrinology. 1994;135(2):798-800.

86. Barak Y, Nelson MC, Ong ES, Jones YZ, Ruiz-Lozano P, Chien KR, et al. PPARy is required for placental, cardiac, and adipose tissue development. Molecular cell. 1999;4(4):585-95.

87. Hegele RA, Cao H, Frankowski C, Mathews ST, Leff T. PPARG F388L, a transactivation-deficient mutant, in familial partial lipodystrophy. Diabetes. 2002;51(12):3586-90.

88. Agarwal AK, Garg A. A novel heterozygous mutation in peroxisome proliferatoractivated receptor-y gene in a patient with familial partial lipodystrophy. The Journal of Clinical Endocrinology \& Metabolism. 2002;87(1):408-.

89. Savage DB, Tan GD, Acerini CL, Jebb SA, Agostini M, Gurnell M, et al. Human metabolic syndrome resulting from dominant-negative mutations in the nuclear receptor peroxisome proliferator-activated receptor- $\gamma$. Diabetes. 2003;52(4):910-7.

90. Farmer SR. Regulation of PPARgamma activity during adipogenesis. International journal of obesity (2005). 2005;29 Suppl 1:S13-6. 
91. Rosen ED, Walkey CJ, Puigserver P, Spiegelman BM. Transcriptional regulation of adipogenesis. Genes \& development. 2000;14(11):1293-307.

92. Linhart HG, Ishimura-Oka K, DeMayo F, Kibe T, Repka D, Poindexter B, et al. $\mathrm{C} / \mathrm{EBPa}$ is required for differentiation of white, but not brown, adipose tissue. Proceedings of the National Academy of Sciences. 2001;98(22):12532-7.

93. Tanaka T, Yoshida N, Kishimoto T, Akira S. Defective adipocyte differentiation in mice lacking the C/EBPB and/or C/EBPD gene. The EMBO journal. 1997;16(24):7432-43.

94. Yen PM. Physiological and molecular basis of thyroid hormone action. Physiological reviews. 2001;81(3):1097-142.

95. KOENIG RJ. Thyroid hormone receptor coactivators and corepressors. Thyroid. 1998;8(8):703-13.

96. Spiegelman B. PPAR-gamma: adipogenic regulator and thiazolidinedione receptor. Diabetes. 1998;47(4):507-14.

97. Adams M, Montague CT, Prins JB, Holder JC, Smith SA, Sanders L, et al. Activators of peroxisome proliferator-activated receptor gamma have depot-specific effects on human preadipocyte differentiation. Journal of Clinical Investigation. $1997 ; 100(12): 3149$.

98. Boyault S, Simonin M-A, Bianchi A, Compe E, Liagre B, Mainard D, et al. 15Deoxy- $\Delta 12$, 14-PGJ2, but not troglitazone, modulates $\mathrm{IL}-1 \beta$ effects in human chondrocytes by inhibiting NF-kB and AP-1 activation pathways. FEBS letters. $2001 ; 501(1): 24-30$.

99. Nolte RT, Wisely GB, Westin S, Cobb JE, Lambert MH, Kurokawa R, et al. Ligand binding and co-activator assembly of the peroxisome proliferator-activated receptor-gamma. Nature. 1998;395(6698):137-43.

100. Ye J-p. Challenges in drug discovery for thiazolidinedione substitute. Acta Pharmaceutica Sinica B. 2011;1(3):137-42.

101. Nissen SE, Wolski K. Effect of rosiglitazone on the risk of myocardial infarction and death from cardiovascular causes. New England Journal of Medicine. 2007;356(24):2457-71. 
102. Kahn SE, Hull RL, Utzschneider KM. Mechanisms linking obesity to insulin resistance and type 2 diabetes. Nature. 2006;444(7121):840-6.

103. Randle PJ, Garland PB, Hales CN, Newsholme EA. The glucose fatty-acid cycle. Its role in insulin sensitivity and the metabolic disturbances of diabetes mellitus. Lancet (London, England). 1963;1(7285):785-9.

104. Bruning JB, Chalmers MJ, Prasad S, Busby SA, Kamenecka TM, He Y, et al. Partial agonists activate PPARy using a helix 12 independent mechanism. Structure. 2007;15(10):1258-71.

105. Amato AA, Rajagopalan S, Lin JZ, Carvalho BM, Figueira AC, Lu J, et al. GQ16, a novel peroxisome proliferator-activated receptor gamma (PPARgamma) ligand, promotes insulin sensitization without weight gain. The Journal of biological chemistry. 2012;287(33):28169-79.

106. Coelho MS, de Lima CL, Royer C, Silva JB, Oliveira FC, Christ CG, et al. GQ16, a TZD-Derived Partial PPARy Agonist, Induces the Expression of ThermogenesisRelated Genes in Brown Fat and Visceral White Fat and Decreases Visceral Adiposity in Obese and Hyperglycemic Mice. PloS one. 2016;11(5):e0154310.

107. Yamada S, Kakuta H. Retinoid X receptor ligands: a patent review (2007-2013). Expert opinion on therapeutic patents. 2014;24(4):443-52.

108. Zhang H, Zhou R, Li L, Chen J, Chen L, Li C, et al. Danthron functions as a retinoic $X$ receptor antagonist by stabilizing tetramers of the receptor. The Journal of biological chemistry. $2011 ; 286(3): 1868-75$.

109. Brtko J. Retinoids, rexinoids and their cognate nuclear receptors: character and their role in chemoprevention of selected malignant diseases. Biomed Pap Med Fac Univ Palacky Olomouc Czech Repub. 2007;151(2):187-94.

110. Bugge TH, Pohl J, Lonnoy O, Stunnenberg HG. RXR alpha, a promiscuous partner of retinoic acid and thyroid hormone receptors. Embo j. 1992;11(4):1409-18.

111. Lee S-K, Lee B, Lee JW. Mutations in retinoid $X$ receptor that impair heterodimerization with specific nuclear hormone receptor. Journal of Biological Chemistry. 2000;275(43):33522-6. 
112. Mangelsdorf DJ, Borgmeyer U, Heyman RA, Zhou JY, Ong ES, Oro AE, et al. Characterization of three RXR genes that mediate the action of 9-cis retinoic acid. Genes \& development. 1992;6(3):329-44.

113. Kliewer SA, Umesono K, Noonan DJ, Heyman RA, Evans RM. Convergence of 9-cis retinoic acid and peroxisome proliferator signalling pathways through heterodimer formation of their receptors. Nature. 1992;358(6389):771-4.

114. DiRenzo J, Söderstrom M, Kurokawa R, Ogliastro M-H, Ricote M, Ingrey S, et al. Peroxisome proliferator-activated receptors and retinoic acid receptors differentially control the interactions of retinoid $X$ receptor heterodimers with ligands, coactivators, and corepressors. Molecular and cellular biology. 1997;17(4):2166-76.

115. Chandra V, Huang P, Hamuro Y, Raghuram S, Wang Y, Burris TP, et al. Structure of the intact PPAR- $\gamma-R X R-\alpha$ nuclear receptor complex on DNA. Nature. 2008;456(7220):350-6.

116. Pinaire JA, Reifel-Miller A. Therapeutic potential of retinoid $\mathrm{x}$ receptor modulators for the treatment of the metabolic syndrome. PPAR research. 2007;2007:94156.

117. Nishikawa J, Mamiya S, Kanayama T, Nishikawa T, Shiraishi F, Horiguchi T. Involvement of the retinoid $X$ receptor in the development of imposex caused by organotins in gastropods. Environ Sci Technol. 2004;38(23):6271-6.

118. Kanayama T, Kobayashi N, Mamiya S, Nakanishi T, Nishikawa J-i. Organotin compounds promote adipocyte differentiation as agonists of the peroxisome proliferator-activated receptor $\mathrm{Y} /$ retinoid $\mathrm{X}$ receptor pathway. Molecular pharmacology. 2005;67(3):766-74.

119. Harada S, Hiromori Y, Nakamura S, Kawahara K, Fukakusa S, Maruno T, et al. Structural basis for PPARgamma transactivation by endocrine-disrupting organotin compounds. Scientific reports. 2015;5:8520.

120. Harper JM. Wild-derived mouse stocks: an underappreciated tool for aging research. Age (Dordrecht, Netherlands). 2008;30(2-3):135-45.

121. Surwit RS, Kuhn CM, Cochrane C, McCubbin JA, Feinglos MN. Diet-induced type II diabetes in C57BL/6J mice. Diabetes. 1988;37(9):1163-7. 
122. Coleman D. Obese and diabetes: two mutant genes causing diabetes-obesity syndromes in mice. Diabetologia. 1978;14(3):141-8.

123. Penza M, Jeremic M, Marrazzo E, Maggi A, Ciana P, Rando G, et al. The environmental chemical tributyltin chloride (TBT) shows both estrogenic and adipogenic activities in mice which might depend on the exposure dose. Toxicology and applied pharmacology. 2011;255(1):65-75.

124. Pent K, Hunn J. Organotins in freshwater harbors and rivers: temporal distribution, annual trends and fate. Environmental Toxicology and Chemistry. 1995;14(7):1123-32.

125. Shawky S, Emons H. Distribution pattern of organotin compounds at different trophic levels of aquatic ecosystems. Chemosphere. 1998;36(3):523-35.

126. Shue MF, Chen TC, Bellotindos LM, Lu MC. Tributyltin distribution and producing androgenic activity in water, sediment, and fish muscle. J Environ Sci Health B. $2014 ; 49(6): 432-8$.

127. Ellis DV. New dangerous chemicals in the environment: lessons from TBT. Marine pollution bulletin. 1991;22(1):8-10.

128. Leary S, Underwood W, Anthony R, Cartner S, Corey D, Grandin T, et al. AVMA guidelines for the euthanasia of animals: 2013 edition. 2013.

129. James WP. WHO recognition of the global obesity epidemic. International journal of obesity (2005). 2008;32 Suppl 7:S120-6.

130. WHO. Obesity and overweight: Updated June 2016; 2016 [cited 2016 31/10/2016]. Available from: http://www.who.int/mediacentre/factsheets/fs311/en/.

131. Mayerson AB, Hundal RS, Dufour S, Lebon V, Befroy D, Cline GW, et al. The effects of rosiglitazone on insulin sensitivity, lipolysis, and hepatic and skeletal muscle triglyceride content in patients with type 2 diabetes. Diabetes. 2002;51(3):797-802.

132. Joseph GY, Javorschi S, Hevener AL, Kruszynska YT, Norman RA, Sinha M, et al. The effect of thiazolidinediones on plasma adiponectin levels in normal, obese, and type 2 diabetic subjects. Diabetes. 2002;51(10):2968-74. 
133. Ohno H, Shinoda K, Spiegelman BM, Kajimura S. PPARY agonists induce a white-to-brown fat conversion through stabilization of PRDM16 protein. Cell metabolism. 2012;15(3):395-404.

134. Chen Y, Zuo Z, Chen S, Yan F, Chen Y, Yang Z, et al. Reduction of spermatogenesis in mice after tributyltin administration. Toxicology. 2008;251(1):21-7. 135. Ueno S, Susa N, Furukawa Y, Sugiyama M. Role of cytochrome P450 in hepatotoxicity induced by di-and tributyltin compounds in mice. Archives of toxicology. $1995 ; 69(9): 655-8$.

136. Sonoda J, Pei L, Evans RM. Nuclear receptors: decoding metabolic disease. FEBS letters. 2008;582(1):2-9. 
A APÊNDICE - A - FICHA AVALIATIVA DE TECIDO
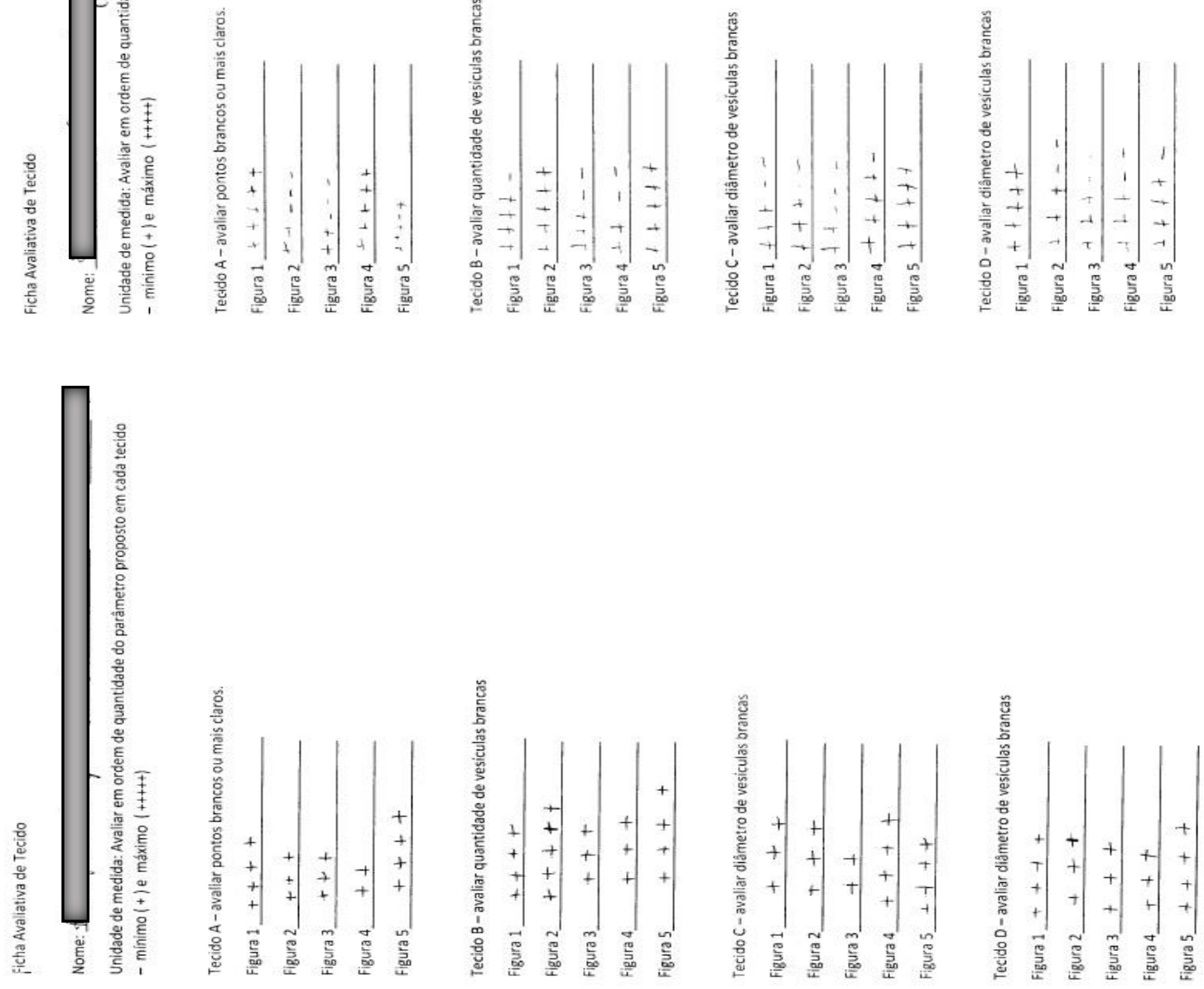
ANEXO A - APROVAÇÃO DA COMISSÃO DE ÉTICA NO USO ANIMAL

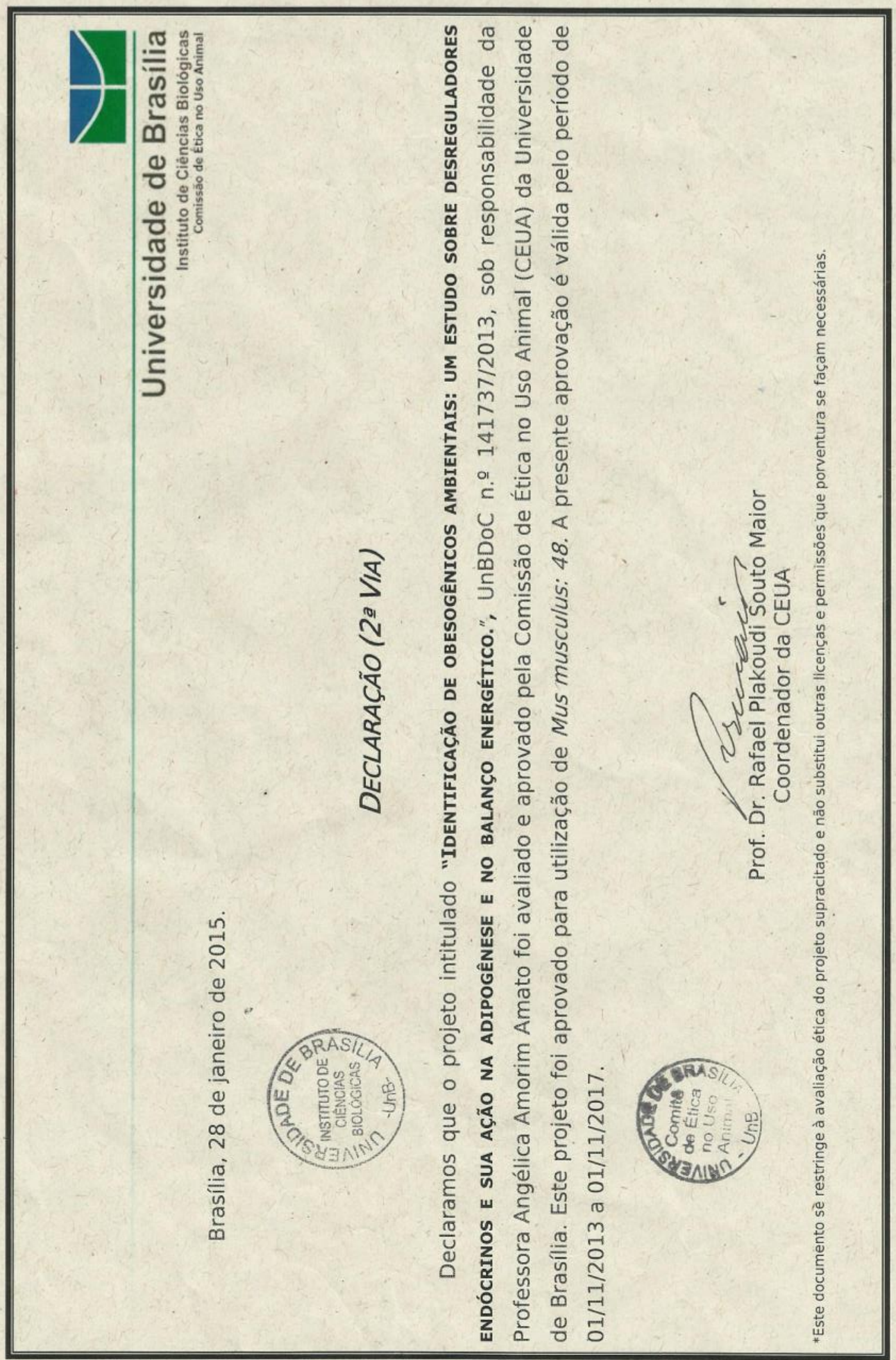


ANEXO B - APROVAÇÃO DA COMISSÃO DE ÉTICA NO USO ANIMAL (ADENDO)

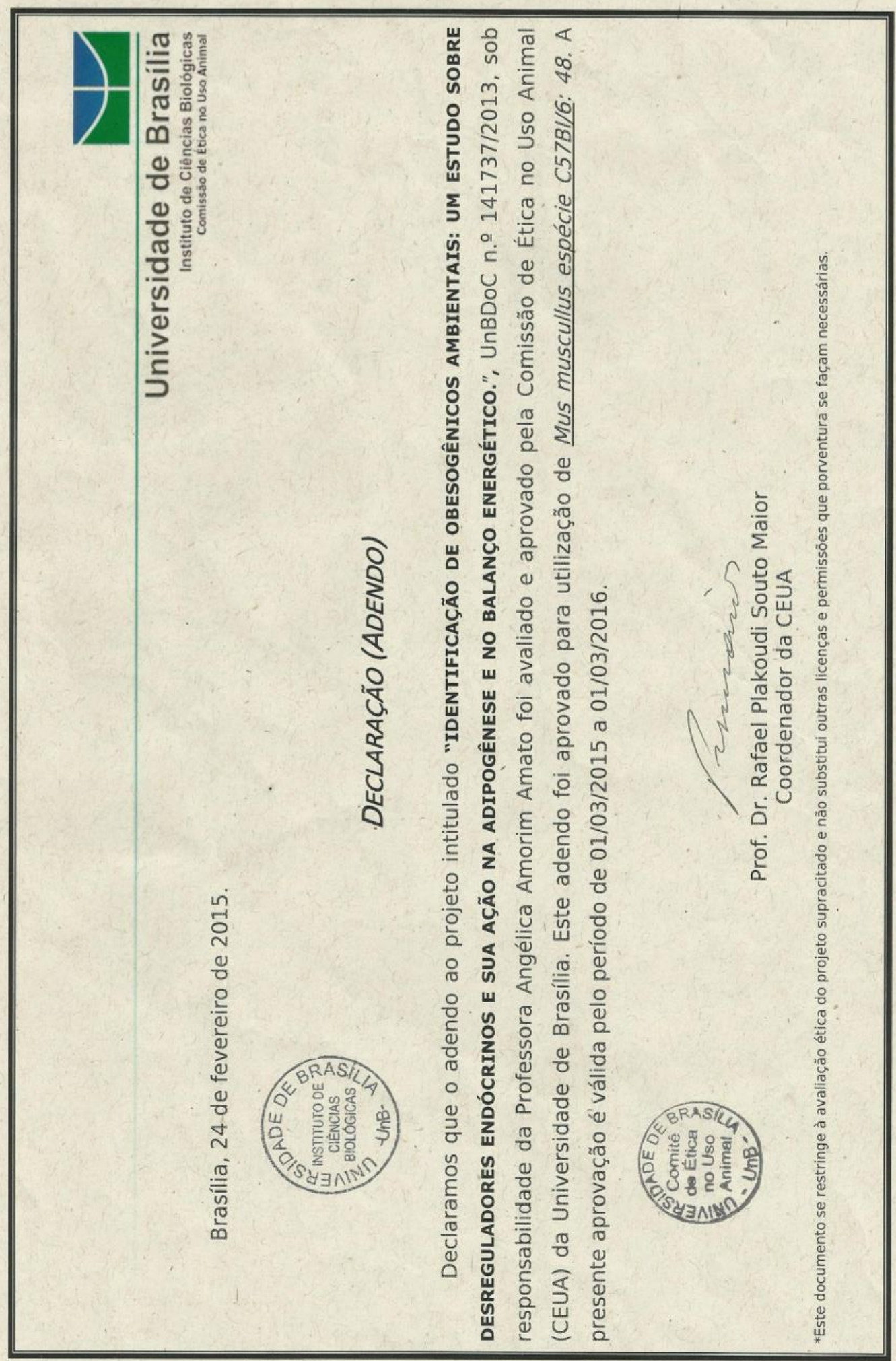




\section{ANEXO C - DIETA NORMOLIPÍDICA}

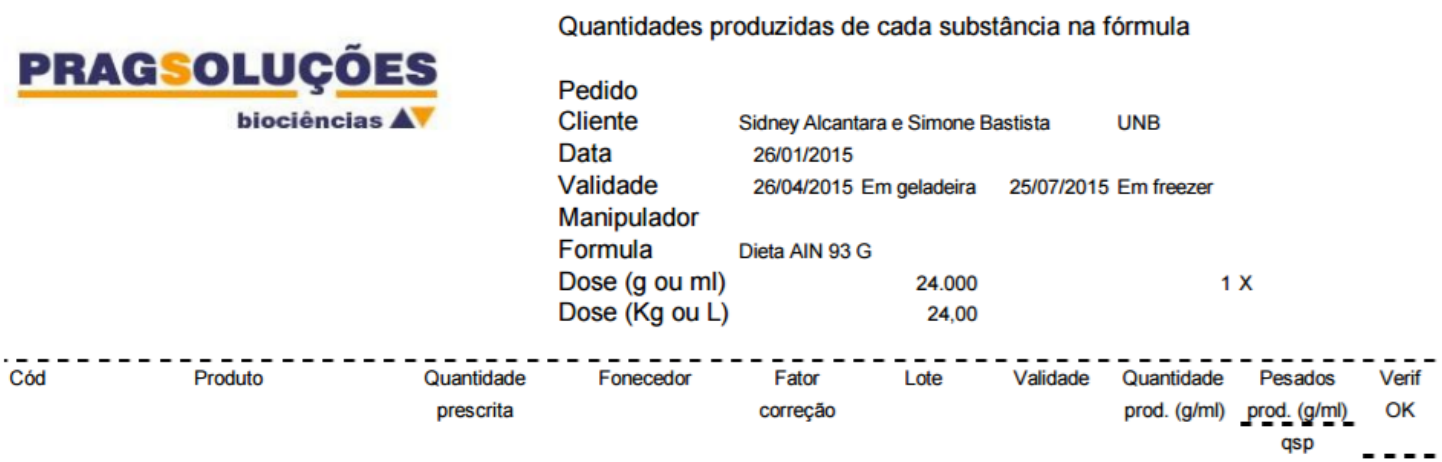

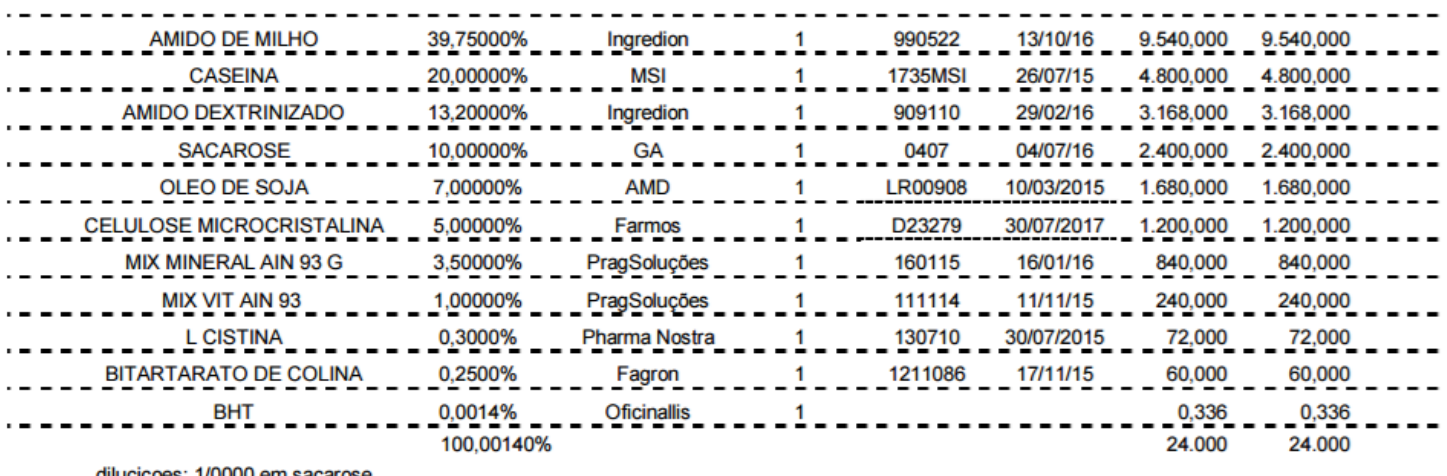

dilucicoes: $1 / 0000$ em sacarose 


\section{ANEXO D - DIETA HIPERLIPIDICA}

\section{1) CONTROLE}

PRAGSOLUÇÕES

biociências $\Delta$

Quantidades produzidas de cada substância na fórmula

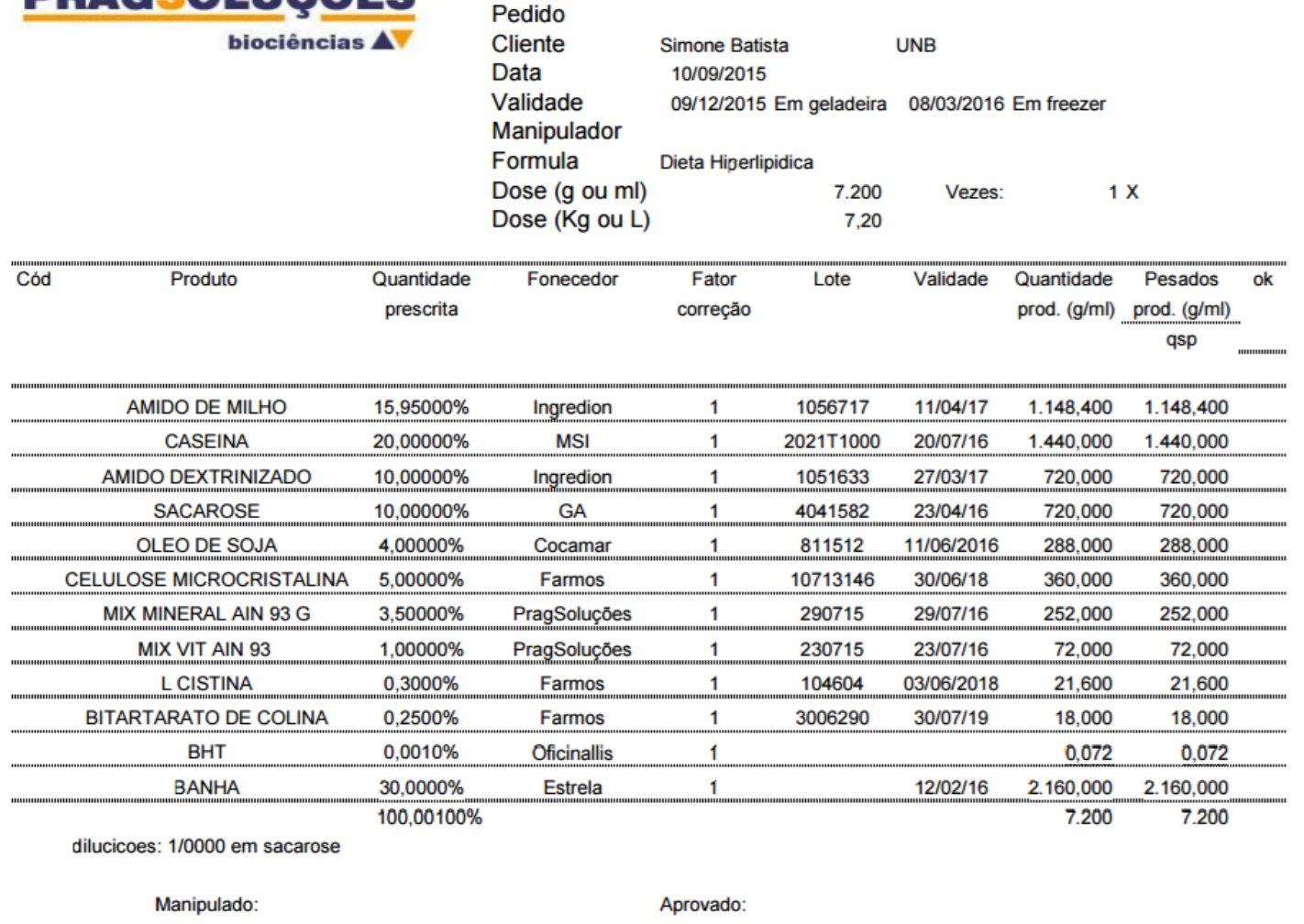

Obs Produto destinado a pesquisa. Isento de registro no Ministério da Agricultura Pecuária e Abastecimento. 
ANEXO D - DIETA HIPERLIPIDICA

2) ROSIGLITAZONA $10 \mathrm{mg} / \mathrm{Kg}$

PRAGSOLUÇÕES

biociências $\boldsymbol{A}$

Quantidades produzidas de cada substância na fórmula

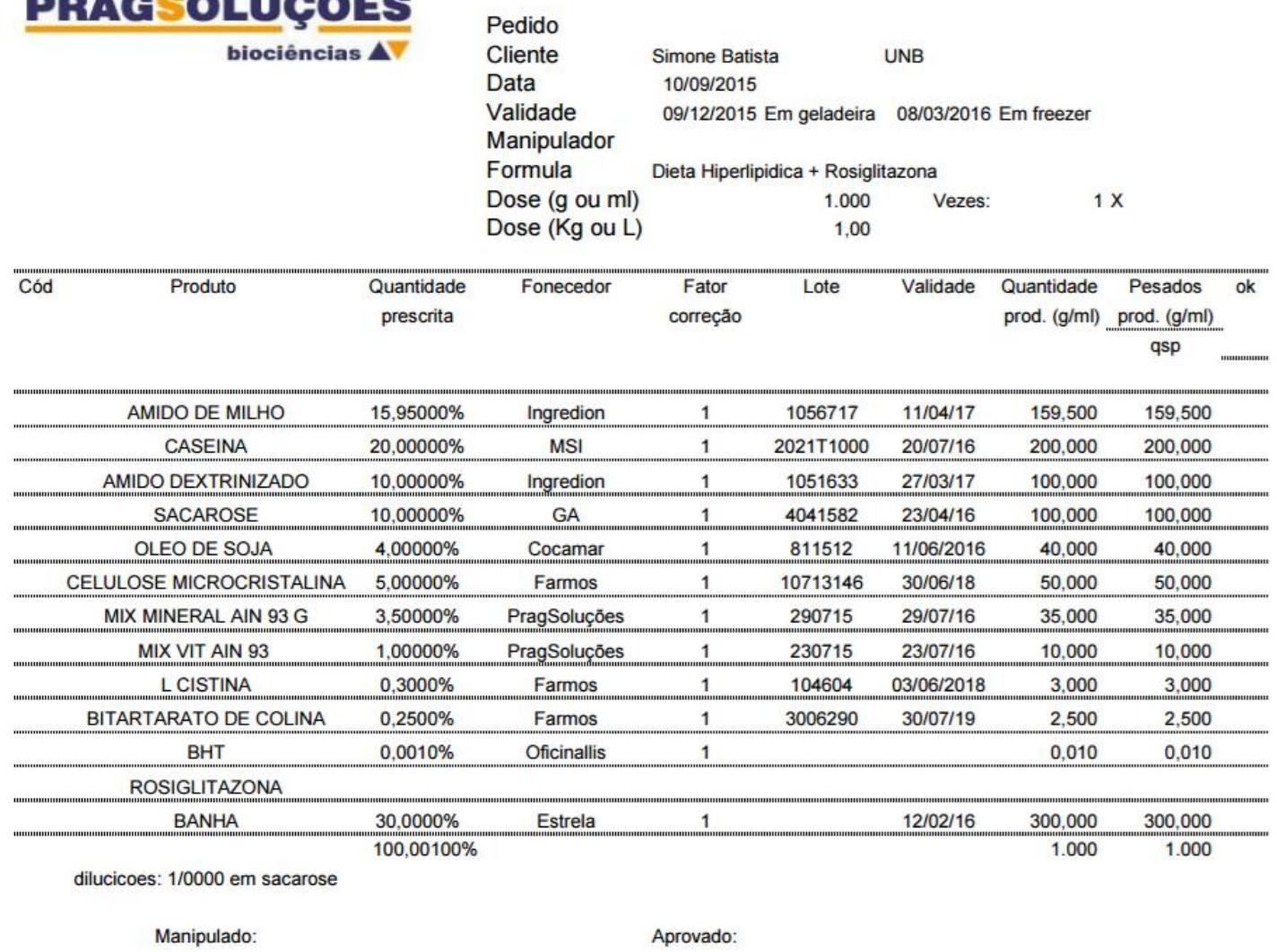

Obs Produto destinado a pesquisa. Isento de registro no Ministério da Agricultura Pecuária e Abastecimento.

Fazer diluição seriada da Rosiglitazona em sacarose 


\section{ANEXO D - DIETA HIPERLIPIDICA}

3) $\mathrm{GQ}-1610 \mathrm{mg} / \mathrm{Kg}$

PRAGSOLUÇÕES biociências $\mathbf{A}$
Quantidades produzidas de cada substância na fórmula

\begin{tabular}{lccl} 
Pedido & \multicolumn{2}{l}{ UNB } \\
Cliente & Simone Batista & & \\
Data & $10 / 09 / 2015$ & & \\
Validade & $09 / 12 / 2015$ Em geladeira & $08 / 03 / 2016$ Em freezer \\
Manipulador & & & $1 \times$ \\
Formula & Dieta Hiperlipidica + QG 16 & \\
Dose $(\mathrm{g}$ ou ml) & 1.000 & Vezes: \\
Dose $(\mathrm{Kg} \mathrm{ou} \mathrm{L)}$ & 1,00 &
\end{tabular}

\begin{tabular}{|c|c|c|c|c|c|c|c|c|}
\hline Cód & Produto & $\begin{array}{l}\text { Quantidade } \\
\text { prescrita }\end{array}$ & Fonecedor & $\begin{array}{l}\text { Fator } \\
\text { correção }\end{array}$ & Lote & Validade & $\begin{array}{l}\text { Quantidade } \\
\text { prod. (g/ml) }\end{array}$ & $\begin{array}{l}\text { Pesados } \\
\text { prod. (g/ml) }\end{array}$ \\
\hline
\end{tabular}

\begin{tabular}{|c|c|c|c|c|c|c|c|}
\hline AMIDO DE MILHO & $\begin{array}{l}15,95000 \% \\
15,000\end{array}$ & Ingredion & 1 & 1056717 & $11 / 04 / 17$ & 159,500 & 159,500 \\
\hline CASEINA & $20,00000 \%$ & MSI & 1 & $2021 \mathrm{~T} 1000$ & $20 / 07 / 16$ & 200,000 & 200,000 \\
\hline 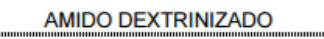 & $10,00000 \%$ & 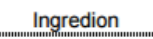 & 1 & 1051633 & 27/03/17 & 100,000 & 100,000 \\
\hline $\begin{array}{l}\text { SACAROSE } \\
\text { SACARn }\end{array}$ & $\begin{array}{l}10,00000 \% \\
0\end{array}$ & GA & 1 & $\begin{array}{l}4041582 \\
4041582\end{array}$ & 23/04/16 & 100,000 & 100,000 \\
\hline OLEO DE SOJA & 4,00000\% & Cocamar & 1 & 811512 & 11/06/2016 & 40,000 & 40,000 \\
\hline CELULOSE MICROCRISTALINA & $5,00000 \%$ & Farmos & 1 & 10713146 & $30 / 06 / 18$ & 50,000 & 50,000 \\
\hline MIX MINERAL AIN 93 G & 3,50000\% & PragSoluçōes & 1 & 290715 & 29/07/16 & $\begin{array}{l}35,000 \\
35\end{array}$ & $\begin{array}{l}35,000 \\
35,00\end{array}$ \\
\hline MIX VIT AIN 93 & $1,00000 \%$ & 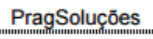 & 1 & 230715 & 23/07/16 & $\begin{array}{l}10,000 \\
10\end{array}$ & $\begin{array}{l}10,000 \\
10\end{array}$ \\
\hline LCISTINA & 0,3000\% & Farmos & 1 & $\begin{array}{l}104604 \\
104\end{array}$ & 03/06/2018 & $\begin{array}{r}3,000 \\
3,000\end{array}$ & $\begin{array}{l}3,000 \\
3,000\end{array}$ \\
\hline BITARTARATO DE COLINA & $0,2500 \%$ & Farmos & 1 & 3006290 & $30 / 07 / 19$ & 2,500 & 2,500 \\
\hline $\mathrm{BHT}$ & $0,0010 \%$ & Oficinallis & 1 & & & 0,010 & 0,010 \\
\hline \multicolumn{8}{|l|}{ QG 16} \\
\hline BANHA & $30,0000 \%$ & & 1 & & $12 / 02 / 16$ & 300,000 & $\begin{array}{r}300,000 \\
300,00\end{array}$ \\
\hline
\end{tabular}

dilucicoes: $1 / 0000 \mathrm{em}$ sacarose

Manipulado:

Aprovado:

Obs Produto destinado a pesquisa. Isento de registro no Ministério da Agricultura Pecuária e Abastecimento.

Fazer diluição seriada do QG 16 em sacarose 
ANEXO D - DIETA HIPERLIPIDICA

4) TBTC $1 \mu g / K g$

PRAgSOluções

biociências $\boldsymbol{A}$

Quantidades produzidas de cada substância na fórmula

Pedido

Cliente

Data

Simone Batista UNB

Validade

09/2015

Manipulador

Formula

09/12/2015 Em geladeira 08/03/2016 Em freezer

Dieta Hiperlipidica + 100 uL TBT

Dose (g ou $\mathrm{ml})$

1.000

Vezes: $\quad 1 \mathrm{X}$

Dose (Kg ou L)

\begin{tabular}{|c|c|c|c|c|c|c|c|c|c|}
\hline Cód & Produto & $\begin{array}{l}\text { Quantidade } \\
\text { prescrita }\end{array}$ & Fonecedor & $\begin{array}{l}\text { Fator } \\
\text { correção }\end{array}$ & Lote & Validade & $\begin{array}{l}\text { Quantidade } \\
\text { prod. ( } / \mathrm{ml} \text { ) }\end{array}$ & $\begin{array}{l}\text { Pesados } \\
\text { prod. (g/ml) } \\
\text { qump }\end{array}$ & ok \\
\hline
\end{tabular}

\begin{tabular}{|c|c|c|c|c|c|c|c|}
\hline 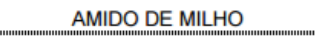 & $\begin{array}{l}15,95000 \% \\
\text { nam, }\end{array}$ & $\begin{array}{l}\text { Ingredion } \\
\text { Ingredion }\end{array}$ & 1 & 1056717 & $\begin{array}{l}11 / 04 / 17 \\
\text { nant }\end{array}$ & $\begin{array}{l}159,500 \\
159,500\end{array}$ & $\begin{array}{l}159,500 \\
159,50\end{array}$ \\
\hline CASEINA & $20,00000 \%$ & MSI & 1 & 2021T1000 & $20 / 07 / 16$ & 200,000 & 200,000 \\
\hline AMIDO DEXTRINIZADO & $10,00000 \%$ & Ingredion & 1 & 1051633 & $27 / 03 / 17$ & 100,000 & 100,000 \\
\hline SACAROSE & $10,00000 \%$ & GA & 1 & 4041582 & 23/04/16 & 100,000 & 100,000 \\
\hline OLEO DE SOJA + 100 uL TBT & $\begin{array}{l}4,00000 \% \\
\text { 4.00 }\end{array}$ & Cocamar & 1 & $\begin{array}{l}811512 \\
812\end{array}$ & $\begin{array}{l}11 / 06 / 2016 \\
\text { 11/2016 }\end{array}$ & $\begin{array}{l}40,000 \\
40,000\end{array}$ & 40,000 \\
\hline CELULOSE MICROCRISTALINA & $5,00000 \%$ & Farmos & 1 & 10713146 & $30 / 06 / 18$ & 50,000 & 50,000 \\
\hline MIX MINERAL AIN 93 G & $\begin{array}{l}3,50000 \% \\
0\end{array}$ & $\begin{array}{l}\text { PragSolucōes } \\
\text { Prom }\end{array}$ & 1 & 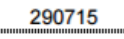 & 29/07/16 & $\begin{array}{l}35,000 \\
35,00\end{array}$ & 35,000 \\
\hline MIX VIT AIN 93 & $1,00000 \%$ & PragSoluçōes & 1 & 230715 & \begin{tabular}{l}
$23 / 07 / 16$ \\
\hdashline $3 / 16$ \\
\hdashline
\end{tabular} & 10,000 & 10,000 \\
\hline LCISTINA & $0,3000 \%$ & Farmos & 1 & 104604 & $03 / 06 / 2018$ & 3,000 & 3,000 \\
\hline 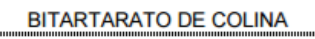 & $0,2500 \%$ & Farmos & 1 & 3006290 & 30/07/19 & 2,500 & $\begin{array}{l}2,500 \\
2,500\end{array}$ \\
\hline BHT & 0,0010\% & 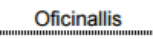 & 1 & & & 0,010 & $\begin{array}{l}0,010 \\
0.010\end{array}$ \\
\hline BANHA & $30,0000 \%$ & Estrela & 1 & & $12 / 02 / 16$ & 300,000 & 300,000 \\
\hline
\end{tabular}

dilucicoes: $1 / 0000 \mathrm{em}$ sacarose

Manipulado:

Aprovado:

Obs Produto destinado a pesquisa. Isento de registro no Ministério da Agricultura Pecuária e Abastecimento.

Diluir os $100 \mathrm{uL}$ de TBT nos $40 \mathrm{~g}$ de óleo de soja 


\title{
ANEXO D - DIETA HIPERLIPIDICA
}

\author{
5) $\mathrm{TBTC} 5 \mu \mathrm{g} / \mathrm{Kg}$
}

PRAGSOLUÇÕES

biociôncias A
Quantidades produzidas de cada substância na fórmula

Pedido

Cliente

Data

Simone Batista UNB

10/09/2015

09/12/2015 Em geladeira 08/03/2016 Em freezer

Manipulador

Formula

Dieta Hiperlipidica + 500 uL TBT

Dose (g ou $\mathrm{ml}$ )

Dose (Kg ou L)
1.000 Vezes: $\quad 1 X$

1,00

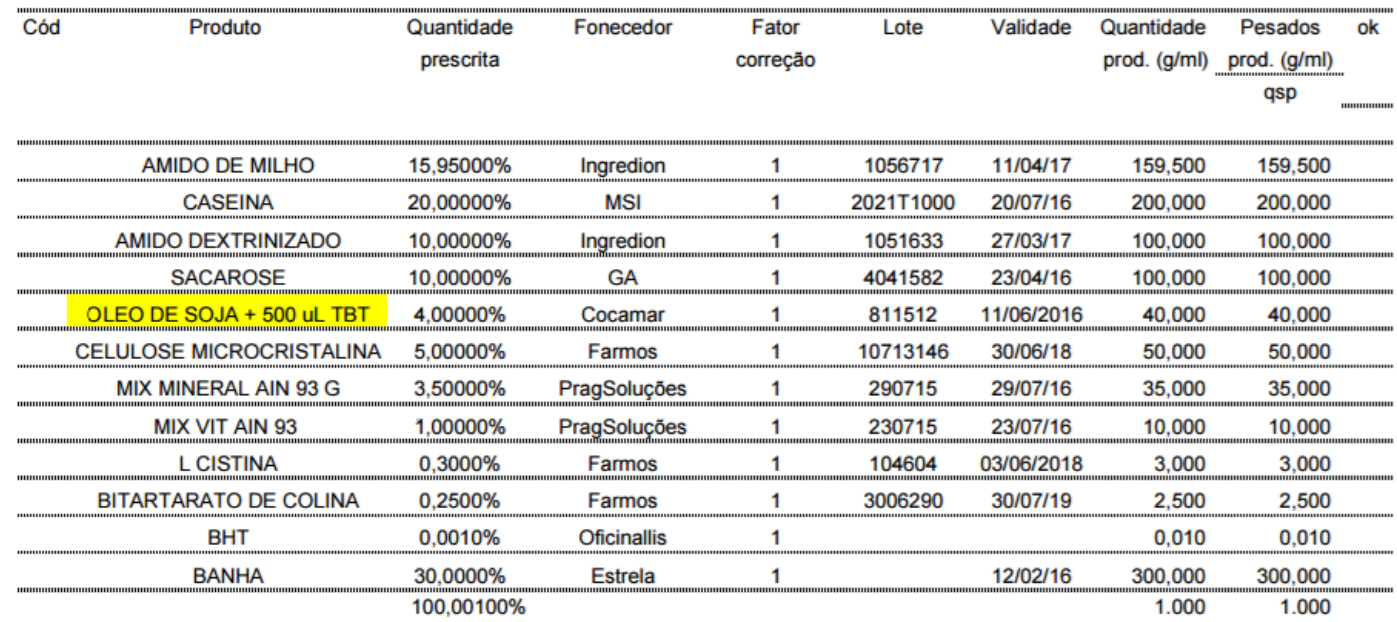

dilucicoes: $1 / 0000 \mathrm{em}$ sacarose

Manipulado:

Aprovado:

Obs Produto destinado a pesquisa. Isento de registro no Ministério da Agricultura Pecuária e Abastecimento.

Diluir os $500 \mathrm{uL}$ de TBT nos $40 \mathrm{~g}$ de óleo de soja 